\title{
ADESÃO AO TRATAMENTO DE HIV/AIDS POR PACIENTES COM AIDS, TUBERCULOSE E USUÁRIOS DE DROGAS DE SÃO PAULO
}

HELENA MARIA MEDEIROS LIMA

Tese apresentada na área de concentração de Epidemiologia da Faculdade de Saúde Pública da Universidade de São Paulo para obtenção do Grau de Doutor. Área de concentração: Epidemiologia

ORIENTADOR: PROF. DR. PÉRICLES ALVES NOGUEIRA

São Paulo, 2006 


\title{
ADESÃO AO TRATAMENTO DO HIV/AIDS POR PACIENTES COM AIDS, TUBERCULOSE E USUÁRIOS DE DROGAS DE SÃO PAULO
}

\author{
HELENA MARIA MEDEIROS LIMA
}

Tese apresentada na área de concentração de Epidemiologia da Faculdade de Saúde Pública da Universidade de São Paulo para obtenção do Grau de Doutor. Área de concentração: Epidemiologia

ORIENTADOR: PROF. DR. PÉRICLES ALVES NOGUEIRA

São Paulo, 2006 


\section{AGRADECIMENTOS}

Agradeço a confiança, a orientação e incentivo do Prof. Dr. Péricles Alves Nogueira, em seu entusiasmo na Saúde Pública e com o tema Tuberculose.

Às Profas. Dras. Maria Inês Baptistella Nemes e Cássia Buchalla, minha gratidão pela leitura cuidadosa e sugestões fundamentais na e pré-banca.

Às Profas. Dras. Margarida Maria Mattos Britto Lemos e Rosalina de Carvalho Silva, pelas contribuições valiosas no exame de qualificação e pré-banca. Também agradeço:

- Richard Needle, do Centers for Disease Control and Prevention/ Global Aids Program;

- Raquel Queiroz, Marleide Silva e a todos os profissionais de saúde dos serviços de Doenças Sexualmente Transmissíveis e Aids do Estado e do Município de São Paulo.

- Equipe do Programa Nacional de Doenças Sexualmente Transmissíveis e Aids do Ministério da Saúde do Brasil.

- Todos os pacientes que são usuários de drogas e estão com aids e tuberculose e se dispuseram a contar suas histórias e contribuir para a melhoria do atendimento em saúde pública no país.

Ao Claudio Dias, Amor e Privilégio.

Aos meus irmãos, Renato Lima, Aline Castro, Marivaldo Júnior, Suporte e Vida.

Ao Movimento SuperAção, aos atores do Vale Encantado, que me ensinaram tanto...

Aos amigos de sempre: Alexandre Magno, Beto Nogueira, Beto Badiani, amigos da

Paróquia Bom Jesus, Roberto Bicelli, Hélio Deliberador, Sr. João e Fátima Castro, Dario Schezzi, todos os Ballespin, Biofa Ulmita, Silvana Zanchetti.

Aos meus pais, a gratidão pela paciência e incentivo em todas as horas. 


\section{RESUMO}

Lima, HMM. Adesão ao tratamento do HIV/Aids por pacientes com aids, tuberculose e usuários de drogas em São Paulo/ SP. São Paulo, 2006. [Tese de doutorado - Faculdade de Saúde Pública da USP].

Objetivo. Subsidiar profissionais de saúde para melhoria das estratégias de adesão e base para Política Nacional de Adesão, definida como o conjunto de atitudes do paciente para melhor aproveitamento do tratamento. Pacientes com aids, tuberculose e usuários de drogas têm dificuldades para aderir.

Métodos. Estudo descritivo, metodologia qualitativa - Rapid Assessment, Response and Evaluation (RARE) em quatro serviços públicos de Doenças Sexualmente Transmissíveis/ Aids de São Paulo, 37 profissionais de saúde (mulheres, casadas, 45 anos) que atendem à população estudada e 27 pacientes (maiores de idade, com aids, tuberculose e usuários de drogas/ 35 anos, sexo masculino, escolaridade baixa, solteiros/ sozinhos, desempregados, diagnóstico de HIV e início de tratamento de aids há mais de cinco anos).

Resultados. Profissionais de saúde sem experiência prévia e capacitações específicas em tuberculose e dependência de psicoativos. Conhecimentos técnicos desatualizados sobre interações, genotipagem, sub-tipos HIV, resistência, falência, tuberculose multidrogarresistente, exceto infectologistas. Sem padronização de conduta para troca de esquema terapêutico de ARV. Exigência de abstinência. Pacientes: ingestão de todas as doses de uma só vez/dia; falhas por esquecimento, uso de drogas (álcool), evitar efeitos colaterais, não-revelação de diagnóstico usuários de crack compartilham cachimbo; trocam médico e/ou serviço para mudar esquema de anti-retrovirais. Serviços de DST/Aids sem interação com Programa de Tuberculose e Saúde Mental.

Conclusões e recomendações. Profissionais de saúde necessitam de capacitações tuberculose e drogas para melhoria da adesão destes pacientes, elaboração de Planos Individuais de Adesão e introdução da Redução de Danos como estratégia; construção da Política Nacional de Adesão.

Descritores: Adesão, Saúde Pública, Tuberculose, Aids, Drogas. 


\section{SUMMARY}

Lima, HMM. Adherence to HIV/Aids treatment among aids/ tuberculosis and drug users patients in Sao Paulo, Brazil. Sao Paulo (BR); 2006. [PhD Thesis - Faculdade de Saúde Pública da Universidade de São Paulo Brazil].

Objective. Give subsidies for improve strategies and build a National Policy of Adherence, understanding as patient behavior related to best use of treatment. Patients with aids, tuberculosis and drug user have difficulties with adherence. Methods. Study descriptive, qualitative methodology - Rapid Assessment, Response and Evaluation (RARE) on four STD/ Aids public services in Sao Paulo. Health professionals who attend targetpopulation (37 women, married, and between 40 - 45 years old) and patients (27, 18 years old or more, aids, tuberculosis and drug users, male, low level of education, single/ lonely, unemployed, with HIV diagnosed and aids treatment began more than 5 years ago).

Results. Health professionals without previous experience in tuberculosis and psychoactive dependence. Fail technical knowledge about: interaction, genotyping, HIV sub-types, resistance, failure, multidrugresistant, tuberculosis. Requesting information from infectologist doctors. There is no standard policy for orientation about the side effects, tuberculosis prophylaxis, adherence and drugs (abstinence request). Patients ingesting all the day dose in one shot; failures to forgetting, to avoid side effects, drug use (alcohol) or non-revelation of the diagnosis; without communication. Switch doctor and/or services to change the antiretroviral scheme; crack users share pipes. Researched STD/Aids services do not have interaction with the Tuberculosis and Mental Health Program. Epidemiological and treatment documents are loosed and have no flow. Conclusions and recommendations. Health professionals could be benefit with capacity in tuberculosis and drugs to develop strategies to improve adherence, as Individual Adherence Plan and introduction of Harm Reduction Strategy. Recommendation to National Program of STD/Aids: develop a National Adherence Policy.

Descriptors: Adherence, Public Health, Tuberculosis, Aids, Drugs. 


\section{INDICE}

Tema

1. INTRODUÇÃO

1.1. Adesão

1.2. Síndrome da imunodeficiência adquirida: aids

1.3. Tuberculose

1.4.Co-infecção aids/tuberculose

1.5. Drogas

2. OBJETIVOS

2.1. Objetivo Geral

2.2. Objetivos Específicos

3. METODOLOGIA

3.1. Metodologia da Coleta de Dados

3.2 Instrumentos de pesquisa: roteiros

3.3. Caracterização da população e serviços selecionados

3.4 Padronização do material coletado

3.5. Metodologia de Análise dos dados

4. RESULTADOS E DISCUSSÃO

4.1. Adesão

4.2. Tuberculose

5. CONCLUSÕES E RECOMENDAÇÕES

6. BIBLIOGRAFIA

7. ANEXOS
Página

11

11

29

42

47

49

56

57

60

63

67

81

81

83

114

143

147

162 


\section{QUADROS:}

Quadro 1. Critérios de definição de casos de aids no Brasil em indivíduos com 1332 anos ou mais. Ministério da Saúde, 2003.

Quadro 2. Situação da tuberculose no Brasil no ano 2000

Quadro 3. Risco de desenvolvimento de tuberculose em pacientes infectados pelo 48 M. tuberculosis em função do status sorológico para HIV

Quadro 4. Eixos temáticos e questões correspondentes das entrevistas a 64 profissionais de saúde, médicos e não-médicos, em quatro serviços de São Paulo, 2005

Quadro 5. Eixos temáticos e questões correspondentes das entrevistas a 65 profissionais de saúde, médicos e não-médicos, em quatro unidades de saúde de São Paulo, 2005.

Quadro 6. Eixos temáticos e questões correspondentes das entrevistas a pacientes 66 com AIDS, tuberculose e usuários de drogas em quatro unidades de saúde de São Paulo, 2005.

Quadro 7. Serviços de Saúde de São Paulo segundo tipo de atendimento prestado e 70 localização. São Paulo, 2005.

\section{TABELAS:}

Tabela 1. Incidência de tuberculose no Brasil até 1996. Brasil, 2000. Tabela 2. Número de adultos acima de 15 anos de idade co-infectados 48 aids/tuberculose no final do ano 2000.

Tabela 3. Profissionais de saúde médicos e não-médicos entrevistados nos quatro 70 serviços de saúde de São Paulo, segundo tipo de serviço, 2005

Tabela 4. Características dos profissionais de saúde entrevistados nos serviços de 72 DST/Aids de São Paulo/ Brasil, que atendem pacientes com aids, tuberculose usuários de drogas. São Paulo, Brasil, 2005.

Tabela 5. Pacientes entrevistados por serviço de DST/Aids, nos quatro serviços de 75 saúde de São Paulo, 2005.

Tabela 6. Caracterização dos 27 pacientes usuários de drogas com aids e 76 
tuberculose entrevistados. São Paulo, Brasil, 2005.

Tabela 7. Número e freqüência de pacientes entrevistados nos quatro serviços de 85 saúde de São Paulo, segundo abandono do tratamento da aids, 2005.

Tabela 8. Número e freqüência de pacientes entrevistados nos quatro serviços de 85 saúde de São Paulo, segundo número de interrupções do tratamento da aids, 2005.

Tabela 9. Número de pacientes entrevistados nos quatro serviços de saúde de São 86 Paulo, segundo tipo de serviço e abandono de tratamento de aids, 2005.

Tabela 10. Abandono do tratamento atual para tuberculose, segundo o total de 87 pacientes entrevistados nos quatro serviços de saúde de São Paulo. São Paulo, 2005.

Tabela 11. Abandono do tratamento atual para tuberculose, segundo cada um dos 87 serviços pesquisados. São Paulo, 2005.

Tabela 12. Número e freqüência de pacientes entrevistados nos quatro serviços de 101 saúde de São Paulo, segundo tempo de infecção e abandono do tratamento da aids. São Paulo, 2005

Tabela 13. Tempo de tratamento em aids e referência a abandono, pacientes com 102 aids/tuberculose, usuários de drogas. São Paulo, 2005.

Tabela 14. Tipos de tratamento de tuberculose(s) anterior (es) descritos pelos 109 pacientes entrevistados. São Paulo, 2005

Tabela 15. Tipo de tratamento da Tuberculose atual, segundo pacientes 109 entrevistados. São Paulo, 2005.

Tabela 16. Pacientes do serviço SM1, segundo tipo de patologia. São Paulo, 2005. 115 Tabela 17. Pacientes do serviço SM2, segundo tipo de patologia. São Paulo, 2005. 118 Tabela 18. Pacientes do serviço SM3, segundo tipo de patologia. São Paulo, 2005. 120 


\section{ANEXOS}

ANEXO 1 - Diretrizes de Aconselhamento em HIV/Aids do Ministério da Saúde.

ANEXO 2 - Consenso para Tratamento de pacientes adultos infectados pelo HIV: normas para tratamento de co-infecção aids/tuberculose.

ANEXO 3A - Termo de Consentimento Livre e Esclarecido para pacientes.

ANEXO 3B - Termo de Consentimento Livre e Esclarecido para profissionais de saúde.

ANEXO 4 - Roteiro de Observação e Mapeamento.

ANEXO 5 - Roteiro para entrevistas com profissionais de saúde.

ANEXO 6 - Roteiro para entrevistas com pacientes.

ANEXO 7 - Categorias gerais e sub-categorias para análise qualitativa - entrevistas

realizadas com pacientes.

ANEXO 8 - Categorias gerais e sub-categorias para análise qualitativa - entrevistas realizadas com profissionais de saúde.

ANEXO 9 - Categorias para análise qualitativa - entrevistas realizadas com profissionais de saúde acerca dos serviços.

ANEXO 10 - Codificação em SPSS dos dados de caracterização dos pacientes selecionados para o estudo.

ANEXO 11 - Codificação em SPSS dos dados de caracterização dos profissionais de saúde selecionados para o estudo. 


\section{LISTA DE SIGLAS}

AIDS - Adquired Immunodeficiency Syndrome (Síndrome da Imunodeficiência Adquirida)

ARV - Anti-Retrovirais

AZT - Zidovudina

DOT - Directly Observed Treatment (Tratamento Supervisionado)

DOTS - Directly Observed Treatment Short (Tratamento Supervisionado de curto prazo)

DST - Doenças Sexualmente Transmissíveis

FNS - Fundação Nacional de Saúde

HAART - Highly Active Anti Retroviral Therapy (Terapia de Alto Impacto)

HIV - Human Immunodeficency Virys (Vírus da imunodeficiência Humana)

IP - Inibidores de Protease

ITRN - Inibidores da Transcriptase Reversa Análogos de Nucleosídeos

ITRNN - Inibidores da Transcriptase Reversa Não-Análogos de Nucleosídeos

IUATLD - International Union Against Tuberculosis and Lung Disease (Liga

Internacional contra Tuberculose e Doenças Pulmonares)

MS - Ministério da Saúde do Brasil

OMS - Organização Mundial de Saúde

OPAS - Organização Pan-Americana de Saúde

PAHO - Pan American Health Organization (Organização Pan-Americana de Saúde)

PN/ DST e Aids - Programa Nacional de DST e Aids

SE - Serviço Estadual

SM - Serviço Municipal

SUS - Sistema Único de Saúde

TARV - Terapia com Anti-Retrovirais

TB - Tuberculose

WHO - World Heath Organization (Organização Mundial da Saúde) 


\section{INTRODUCÃ̃}

\section{1. ADESÃO - A adesão ao tratamento de aids e tuberculose e o uso de drogas no Brasil: políticas públicas}

A questão da adesão ao tratamento da aids no Brasil vem ganhando importância cada vez maior nestes mais de 20 anos de epidemia. Em função de uma determinação Federal, o Sistema Único de Saúde fornece todos os pacientes infectados pelo HIV acesso ao tratamento e aos medicamentos pelo serviço público. O acesso universal é tema de intensos debates no panorama internacional, em que a diretriz da Organização Mundial de Saúde - chamada "3 by 5" - e o tema da adesão é utilizado, muitas vezes, como justificativa para imposição de barreiras para expansão do tratamento da aids em países pobres.

O Brasil apresenta 317.827 casos notificados de aids (MINISTÉRIO DA SAÚDE 2005a), e cerca de 170.000 pessoas em tratamento anti-retroviral. Houve 85.000 novos casos de tuberculose em 2005 e cerca de 6.000 mortes. O avanço da aids também contribuiu para o avanço da tuberculose, pois cerca de $25 \%$ dos soropositivos desenvolvem a doença. Houve recrudescimento da tuberculose em função da epidemia de aids (LEITE 2006).

É consenso que uma das maiores dificuldades nos tratamentos de aids e tuberculose é o alto índice de abandono antes do prazo. Melhoras nos sintomas, excesso de efeitos colaterais, dentre outros fatores, contribuem para uma baixa adesão ao tratamento completo. Para evitar o abandono, é preciso um acompanhamento do poder público, com equipes preparadas para orientar o paciente (LEITE 2006).

Em doenças crônicas, muitas vezes o ato de ingerir o medicamento é entendido como a referência direta e inequívoca à doença e seu caráter crônico. Considerando-se o caráter estigmatizante da aids, da tuberculose e o preconceito em relação aos usuários de drogas, pode-ser compreender o porquê de tantos 'esquecimentos' mencionados pelos pacientes (ver resultados), e a necessidade de aprimoramento dos Planos Individuais de Adesão. A taxa média de adesão observada em inúmeros estudos de doenças crônicas tem se situado em torno de $50 \%$ para todos os tipos de tratamento (MINISTÉRIO DA SAÚDE 2000a).

No presente estudo, será discutido o tema da adesão ao tratamento de aids por 
pacientes com co-morbidade aids-tuberculose, aspecto que emergiu como um dos mais importantes na aids nos últimos anos especialmente, após o advento da terapia antiretroviral em 1996, na questão particular dos usuários de drogas. São constantes os questionamentos (na sociedade civil e mesmo entre profissionais de saúde) acerca do mérito dos pacientes usuários de drogas receberem medicação anti-retroviral e de tuberculose gratuitamente do Governo Federal via Sistema Único de Saúde, bem como o direito destes pacientes de serem atendidos na rede pública de saúde. Esse julgamento moral pode ser analisado em diversas perspectivas, desde a herança cultural de abordagem do tema drogas e a dependência como transgressão e fraqueza do sujeito em termos morais.

Em relação à aids, embora o Programa Nacional de DST/Aids (vinculado ao Ministério da Saúde) exista desde 1985, tenha visibilidade mundial, e vários de seus assessores técnicos e consultores sejam solicitados por organizações internacionais - como as Organizações Pan-Americana e Mundial da Saúde - para auxílio na construção de políticas públicas, ainda em 2006 não se desenvolveu uma Política Nacional de Adesão.

A Política Nacional de Adesão pode ser norteadora das orientações para aprimoramento da adesão dos pacientes, dos critérios nacionais para as mudanças de esquemas terapêuticos, e as diretrizes para o atendimento dos pacientes com aids, em geral e em particular os co-infectados por tuberculose e que sejam usuários de drogas.

Em relação ao tratamento clínico, existem os Consensos, deliberações técnicas construídas por médicos infectologistas experts na área de aids, e são estabelecidas as diretrizes clínicas de administração de remédios. O mais recente ocorreu em agosto de 2005 (ver Anexo 1).

Já a tuberculose tem, no Brasil, ações governamentais estruturadas desde o início do século XX, e o controle se dá de forma organizada desde a criação do Serviço Nacional de Tuberculose em 1941. A partir da década de 70, com a descentralização das ações, e na década de 80 , com a introdução do esquema de curta duração com rifampicina, houve grande aumento de cobertura com significativa redução da mortalidade e da incidência (MINISTÉRIO DA SAÚDE 2002b).

A estrutura no país que organiza as ações sobre a tuberculose no Brasil é o Programa Nacional de Controle da Tuberculose, e sua atual estratégia de reforço é o Plano Nacional de Controle da Tuberculose (MINISTÉRIO DA SAÚDE 2002b). Mesmo assim, 
em 2006 o país descumpriu a meta da Organização Mundial de Saúde de curar 85\% dos casos, ficando no patamar de 75\% de cura (LEITE 2006).

Em relação às drogas psicoativas, o controle, o tratamento e a formulação de políticas públicas ficam a cargo da Secretaria Nacional Anti-Drogas, subordinada ao Gabinete de Segurança Institucional da Presidência da República. A Política Nacional AntiDrogas foi estruturada em 2001 e revista em 2004, em que são estabelecidas as diretrizes de prevenção, assistência, tratamento, repressão, redução de danos e pesquisas (ver no item 4 desta introdução a discussão sobre o abuso de drogas). A área temática de Saúde Mental, do Ministério da Saúde, tem desenvolvido os Centros de Atenção Psicossocial (CAPS) voltados para a área de álcool e drogas (CAPS/Ad), para garantir atendimento a usuários de drogas pelo Sistema Único de Saúde. No entanto, são poucas as ações conjuntas entre Senad e Saúde Mental, e os usuários de drogas ainda são presos e encaminhados a delegacias, sendo o uso de drogas considerado crime e não problema de saúde pública.

Os pacientes com aids, tuberculose e usuários de drogas têm, pela Constituição Brasileira (1988) e pelas diretrizes normatizadas pelas políticas públicas das três áreas, direito a atenção e tratamento de suas patologias pelo Sistema Único de Saúde. As três esferas governamentais (nacional, estadual e municipal) têm responsabilidade em atendêlos sem preconceitos e com a tecnologia e a atualização científica disponíveis.

\subsubsection{Os conceitos de adesão}

A adesão ao tratamento entre pacientes com doenças crônicas é considerada uma questão complexa e de difícil manejo, como por exemplo, em relação aos hipertensos, apenas 30\% dos pacientes em tratamento conseguem manter controle da pressão arterial, seguir a prescrição de dieta e realizar alguma atividade física ${ }^{1}$.

Segundo BRAWLEY e CULOS-REED (2000), os termos mais utilizados na língua inglesa adherence e compliance têm significados diferentes: o termo compliance, que pode ser traduzido como 'obediência', 'cumprimento de regras', pressupõe um papel mais restrito do paciente, que teria como papel apenas cumprir as prescrições médicas.

Já o termo adherence, ou aderência/ adesão, designa uma possibilidade de escolha

\footnotetext{
${ }^{1}$ (< URL:http://www.who.org $>$ ).
} 
livre das pessoas em adotarem ou não certa recomendação, uma 'concordância autônoma' (ou patient empowerment), em que o papel do sujeito mais ativo.

O termo adesão será utilizado como uma relação onde o paciente consegue compreender a própria condição, os aspectos básicos de sua doença e a importância de sua adesão não apenas para melhoria do quadro clínico individual, mas também no contexto da história da doença em questão (WHO 2001). O termo ‘adesão’ em Português parece mais adequado ao sentido preferido de 'concordância autônoma' ou empowerment e vem sendo o mais utilizado.

Esse é um novo entendimento do papel do paciente, não apenas como aquele que cumpre ordens, mas como sujeito ativo, que participa e assume responsabilidades sobre seu tratamento. Autores como CONRAD (1985) e DOWELL e HUDSON (1997), MILSTEINMOSCATI et al (2000), apresentam as dificuldades de implementação deste novo papel na dinâmica da relação médico-paciente.

O atual estágio da epidemia de HIV/Aids neste início de século XXI não traz perspectivas de cura a médio prazo. Com a introdução da terapia anti-retroviral (TARV), em 1996, houve redução significativa da letalidade dos pacientes atingidos e aumento substancial da sobrevida. Em compensação, novos desafios se sobrepõem na assistência aos pacientes HIV/Aids: os efeitos adversos dos medicamentos de curto, médio e longo prazos, como os efeitos estéticos, as interações bioquímicas e fisiopatológicas, a efetividade e a eficácia dos tratamentos considerando-se as co-morbidades e co-infecções, os aspectos psíquicos e sociais dos pacientes.

Em síntese, são questões importantes o comportamento do paciente frente à sua doença, que de modo muitas vezes súbito torna-se parte de sua existência, com exigências de disciplina com horários e modo de vida, suas diversas maneiras de enfrentar os efeitos adversos e seguir sua vida com desejo, produtividade e lucidez, sua saúde e direitos reprodutivos.

A adesão pode ser entendida de várias maneiras: adesão dos profissionais às diretrizes estabelecidas para atendimento; adesão às normas e diretrizes preconizadas nos Conselhos. A adesão do paciente ao tratamento, em conceito estrito, que será a base desta 
tese. O conceito de adesão traz à tona o quanto o paciente aceita sua doença, o quanto conhece e aciona seus recursos psíquicos, emocionais e sociais para enfrentá-la. Se e quanto abdica de projetos de vida afetiva e/ou profissional, e o quento isso se reflete na forma como conduz seu tratamento. Importa compreender se e como o sujeito realiza exames preventivos, se ele tem comportamentos de risco, enfim, se esse paciente consegue tratar-se. É um conceito que vai além da questão dos remédios e prescrições médicas. Considera-se a ingestão de remédios uma condição necessária, mas não suficiente para um bom tratamento.

A adesão ao tratamento pode ser definida como

a utilização dos medicamentos prescritos ou outros procedimentos em pelo menos 80\% do seu total, observando horários, doses, tempo de tratamento, e se foi usado como foi prescrito (LEITE e VASCONCELLOS 2003).

Segundo a Organização Mundial de Saúde (WHO 2004), a adesão pode ser avaliada de diferentes maneiras: como um grau em que o regime prescrito é seguido e expresso como porcentagem ou razão; como um fenômeno categorizado (boa ou má/ baixa adesão) ou como um escore sintetizando vários comportamentos. Cada tratamento, portanto, requer um protocolo particular, que contemple as variáveis envolvidas.

\subsubsection{Não-adesão: definições e possíveis consequências}

Estudos mostram que algum grau de não-adesão ocorre universalmente, tanto em países ricos como em países pobres, ocorrendo mesmo em doenças que envolvem potenciais riscos de vida. Os pacientes têm "momentos de não-adesão", e a história dos que têm boa adesão é uma história de superação de dificuldades (MINISTÉRIO DA SAÚDE 2000).

A aceitação da doença, o contexto sócio-cultural e emocional em que o diagnóstico foi realizado e apresentado interferem diretamente para uma não-adesão. Estudos demonstram que os pacientes, ao receber o diagnóstico de HIV+ ou aids, mesmo com aconselhamento pré e pós-teste, entram em stress pós-traumático, com a mesma sintomatologia (ADÃO 2004).

A não-adesão pode se manifestar em diversas maneiras: pelo simples nãocumprimento parcial ou total das prescrições medicamentosas, descontinuidades e falhas, 
interrupção total ou, em outro extremo, ingestões excessivas e conseqüente overdose.

O profissional de saúde precisa estar atento para essas diversas formas em que a não-adesão pode se manifestar e procurar ajudar a orientar o paciente.

A não-adesão é um fenômeno universal, porém passível de intervenção, pois os fatores determinantes, embora múltiplos e complexos, são conhecidos e existem recursos para essa interferência. O não-uso de medicamentos tal como preconizado nas indicações médicas pode ter diversas conseqüências, tanto para o sujeito, como para a população, uma vez que os efeitos individuais têm reflexos na história clínica da doença.

Importante destacar os prejuízos que a não-adesão provoca, tanto para o paciente, quanto para a história clínica da doença e para a saúde pública em geral. A baixa adesão é um dos problemas mais graves do sistema de assistência à saúde, transformando o melhor tratamento disponível em ineficaz, dentre outros problemas, como será discutido a seguir.

Em primeiro lugar, aumenta o risco de desenvolver resistência às terapias: em pacientes com HIV/AIDS, a resistência a terapia anti-retroviral está relacionada a baixos níveis de adesão (BANGSBERG et al 2000). A adesão baixa ou parcial, menor de 95\%, pode permitir replicação viral, redução da taxa de sobrevivência e mutação de linhagens resistentes de HIV (PATERSON et al 2000). O mesmo ocorre com a tuberculose, onde baixa adesão é reconhecida como a maior causa de falência terapêutica, recaída e resistência a drogas (YACH 1988). Esse é um dos principais argumentos contrários à disponibilização da terapia anti-retroviral em países com dimensões continentais como o Brasil: que não haveria condições para acompanhamento sistemático e as falhas de adesão permitiriam o desenvolvimento de cepas virais altamente resistentes - argumento este que não encontra respaldo científico até o momento.

A baixa adesão persistente pode piorar o curso da doença e eventualmente fazer o paciente perder a condição de responder ao tratamento (WEIDEN 2002), com aumento do risco do chamado 'efeito-rebote' (intoxicações), recaídas e sintomas de abstinência. Podem ocorrer efeitos adversos e danos potenciais quando a medicação é interrompida abruptamente, de modo parcial ou total. Um bom plano individual de adesão (ver item 1.1.5 deste capítulo) diminui a chance do paciente ter experiências adversas decorrentes da interrupção ou descontinuidade (KAPLAN 1997).

A não-adesão também permite aumento do risco de dependência: vários 
medicamentos psicotrópicos produzem dependência severa quando usados de modo inapropriado. Por exemplo, Diazepam, medicamento utilizado para os quadros de aids com comprometimento neurológico (BUSH et al 1984).

O aumento do risco de toxicidade é uma possível conseqüência importante da nãoadesão, entendida também como manifesta no uso excessivo ou abusivo de medicamentos. Existe o risco de overdose de drogas com farmacodinâmica acumulativa - pacientes idosos e com distúrbios mentais (esquizofrenia, por exemplo) são especialmente suscetíveis (BUSH et al 1984).

A não-adesão pode ser proporcionada por vários fatores que atuem em conjunto, como por exemplo (WHO 2001):

1. Falta de disponibilidade de medicamentos na rede de saúde ou falta de condições para aquisição dos mesmos; número de comprimidos por dia: estudos revelam que quanto menor o número de comprimidos diários, melhor pode ser a adesão;

2. Tipo de doença: estigmatizada ou não; falta de apoio psicológico; uso de psicoativos; distúrbios mentais; deficiência mental;

3. Intervenção com foco exclusivo na consulta médica ou seu o oposto, a depreciação da fala do médico e a pouca importância para a consulta clínica: por exemplo, profissionais não-médicos que incentivam o uso de medicação não-alopática, bem como apóiam interrupções no tratamento em função de datas (aniversários, festas, finais de semana), como estratégia para que o paciente siga vinculado;

4. Escolaridade inferior a 4 anos de estudos: baixo nível de escolarização está diretamente relacionado a dificuldades de entendimento dos esquemas terapêuticos, tanto no tratamento da aids isoladamente como no tratamento das comorbidades associadas (NEMES et al 2004); ausência de renda pessoal ou perda do emprego: a falta de vínculos significativos e de ocupação contribuem para o agravamento dos quadros depressivos;

5. Distância entre moradia e Unidade de Saúde: muitos relatos de não-adesão referem-se a essa dificuldade estrutural de locomoção e deslocamento ${ }^{2}$; falta de clareza quanto à rotina de atendimento no serviço de saúde: desconhecimento das condições básicas de fluxo na unidade de atendimento, inflexibilidade no agendamento de horários para consultas e

2. Na cidade de São Paulo, alguns serviços públicos têm convênio com a Secretaria Estadual de Transportes e oferecem vale-transporte, porém apenas em caso de co-infecção diagnosticada e confirmada em laudo próprio. 
exames;

6. Início do tratamento mal conduzido pelo profissional de saúde desde a revelação diagnóstica: desqualificação do doente ou da doença, anúncio inadequado para família, exigência de abstinência imediata para pacientes usuários de drogas.

Para trabalhos com adesão nos serviços públicos de saúde, LIMA e MALTA (2005) consideram os seguintes fatores como importantes para abordagem do tema:

1. Acesso aos medicamentos, relacionado a custo, acessibilidade, disponibilidade; aspectos da complexidade e duração do tratamento, em relação ao nível de escolaridade do paciente; condições sócio-demográficas, relativas às opções e alternativas do paciente; rede social de apoio;

2. Dificuldade para compreensão do esquema terapêutico, em relação à ingestão de comprimidos - horários, requisitos, relação com alimentação (requisitos de jejum, pós-refeição, jejum prolongado); tipo de enfermidade, relativo à forma como o paciente vê seu estado e compreende sua doença; co-morbidades conhecidas, medicadas e controladas: em especial as relativas à saúde mental;

3. Presença ou ausência de sintomas: sem sintomas, a tendência é de interrupção dos medicamentos; efeitos colaterais dos medicamentos, em especial a lipodistrofia;

4. Caráter inter e multidisciplinar da intervenção - características do serviço de assistência - estrutura, rotina, flexibilidades com horários e acesso aos profissionais; abordagem cuidadosa do profissional de saúde no diagnóstico e prescrição - relação entre profissional e paciente; capacidade de diálogo e negociação por parte do profissional de saúde e do próprio serviço, relacionada com alguma flexibilidade de prazos e datas para consultas e retirada de medicamentos, quando for o caso; adesão do paciente ao serviço de saúde.

Para estruturação de uma Política Nacional de Adesão, seria importante considerar que essas diretrizes precisariam ser adaptadas para as diversas realidades regionais. Em locais onde a distância mínima é percorrida em dez horas de barco, como por exemplo em certas regiões de Rondônia, outros aspectos precisarão ser analisados e passíveis de intervenção.

\subsubsection{Modelos de adesão}


Diferentes estratégias fundamentam-se em diferentes modelos de adesão. A WHO (2004) traz como referência cinco modelos básicos para tentar compreender a relação entre o paciente, sua doença e o tratamento, aqui apresentados de modo sintético. Cada modelo tem suas limitações, vantagens e desvantagens, e cabe à equipe profissional avaliar se um ou mais destes métodos poderão ser úteis para o planejamento de um plano individualizado e para o auxílio do paciente em seu tratamento. São eles:

\section{a) Perspectiva biomédica}

É a perspectiva dominante nos serviços de saúde e organizações. Sua base é que os pacientes são "mais" ou "menos" obedientes em seguir as ordens médicas (LEVENTHAL e CAMERON 1987). A não-adesão é atribuída a características pessoais do paciente (traços de personalidade, condições sócio-demográficas) e este é visto como alvo para esforços para melhorar a adesão. Fatores importantes, como o ponto-de-vista do paciente sobre seus sintomas e remédios, suas dificuldades específicas de ingestão de remédios, muitas vezes são totalmente ignorados.

Com este modelo, o doente é culpado pelo profissional de saúde pelo fracasso quase no tratamento, em geral é punido por desobediência, sem que se considere como importantes o vínculo deste paciente com o serviço, a flexibilidade para atendimento, ou mesmo outras dificuldades decorrentes de problemas no serviço, na assistência prestada.

\section{b) Perspectiva comportamental}

Tem como base o behaviorismo skinneriano ${ }^{3}$ (radical) e enfatiza a importância dos reforços positivos e negativos como um mecanismo de influência no comportamento, com base nos antecedentes e conseqüências (SKINNER 1938). Como forma de modelar o comportamento do paciente, os serviços de saúde teriam mecanismos de controle sobre um comportamento específico - por exemplo, punir os atrasos com mudança de horário na agenda do profissional e provocar esperas para o paciente de até dez horas.

\section{c) Comunicação}

Nessa perspectiva,o foco é a melhoria da comunicação dos profissionais de saúde com os pacientes, para que se construa um espaço de confiança e os assuntos considerados polêmicos, pessoais e delicados sejam abordados.

\footnotetext{
${ }^{3}$ De um modo muito resumido, o Behaviorismo Radical é uma abordagem da Psicologia que tem como pressuposto que o homem é uma "tabula rasa" e é totalmente moldado e condicionado pelo ambiente em que é criado e vive (SNIKKER 1938).
} 


\section{d) Cognição}

Inclui vários modelos cognitivos, como a teoria sócio-cognitiva (BANDURA e SWIM 1977) e a teoria da proteção-motivação (ROGERS e PRENTICE-DUNN 1997), dentre outras. A base dessa abordagem é atenção direta ao conceito de saúde dos pacientes e como cada um avalia os fatores que poderiam ser barreiras ou facilitadores da adesão. É o modelo "educacional" em saúde, em que os pacientes participam com o conhecimento que

já têm, e são convidados a participar da construção de seu tratamento. Por exemplo a religião pode ser uma barreira ou um facilitador para adesão, sendo necessário diálogo a respeito e compreensão do significado da vivência religiosa para aquele paciente.

\section{e) Auto-regulação}

Nessa perspectiva, tenta-se integrar variáveis ambientais e respostas cognitivas dos indivíduos em seus cuidados com saúde num modelo de auto-regulação - cuja essência é o conceito cognitivo que o paciente tem do tratamento ou da doença. $O$ paciente cria representações pessoais da doença e do tratamento, e considera-se que essas representações o orientem a tomar decisões e agir de determinado modo. O limite dessa abordagem é o trabalho com pacientes com deficiência ou distúrbio mentais, e pacientes em quadro de intoxicação aguda por psicoativos.

\subsubsection{Medidas de Adesão}

Em relação às formas de avaliação da adesão, é importante destacar que não existe um "padrão ouro" para medir os comportamentos. Existem várias estratégias para avaliar, uma vez que o relato pessoal tende a ser pouco real e superestimado (DIMATTEO e DI NICOLA 1982): pacientes que não seguem a medicação corretamente tendem a descrever seu comportamento como correto (CRAMER E MATESON e MATESON 1991).

Não há consenso para as definições de 'boa' e 'má' adesão, que variam muito entre os estudos. Por isto, é fundamental que as avaliações e comparações entre níveis de adesão sempre considerem o método utilizado e o nível no qual a adesão foi definida. Alguns estudos utilizam como medida de adesão para terapia antiretroviral a utilização de $95 \%$ da medicação prescrita, quando se trata de inibidores de protease (INGERSOLL 2004), porém outros estudos utilizam como parâmetro a ingestão de $80 \%$ da medicação nos últimos três dias, ou no último mês. SULEIMAN (2005) reitera: 
Adesão é de $100 \%$. Tomar o que foi prescrito, zerar carga do agente infeccioso, curar quando possível, minimizar as cargas e cepas quando não houver cura conhecida.

As medidas de adesão podem ser consideradas apenas uma estimativa do comportamento atual do paciente frente a seu tratamento e sua condição. Uma medida considerada 'boa' ou abrangente pode obter uma aproximação do comportamento de adesão, e permite considerar todas as possíveis estratégias utilizadas (NUNNALLY e BERNSTEIN 1994).

As medidas que priorizam a subjetividade tendem a ser menos efetivas do que as medidas mais diretas, referentes a comportamentos que descrevam especificamente as recomendações médicas, sendo uma das técnicas a aplicação de questionários (FARMER 1999).

Duas das tecnologias disponíveis, os marcadores nas tampas dos frascos e marcadores biológicos, podem auxiliar, porém - devido a seu alto custo e limites de efetividade - não têm sido aplicados no Brasil. São eles:

a) Contagem de comprimidos, seja nas consultas, ou ainda o controle pelo monitoramento eletrônico de tampa, e mesmo o controle das planilhas das farmácias onde o remédio é retirado. É um método limitado, que tendem a superestimar a adesão, pois apenas registra que o paciente pegou a medicação (CRAMER E MATESON 1991). Este método depende de tecnologia, banco de dados de farmácias e um mínimo de fidedignidade do paciente em dizer a verdade.

b) Os marcadores biológicos, marcadores não-tóxicos adicionados aos medicamentos, e sua presença no sangue ou urina pode mostrar ao paciente se a ingestão foi recente e na dose correta. Além de ser considerada uma estratégia invasiva pelos pacientes, a utilização de metabólitos para avaliação pode ser influenciada por diversos fatores biológicos individuais, como dieta, absorção, excreção, temperatura, ciclo menstrual no caso das mulheres, etc. (VITOLINS 2000).

Independentemente da técnica de medida utilizada, talvez seja útil o profissional definir "boa" e "má" adesão junto ao paciente e utilizar essa medida no acompanhamento do processo. A relação do paciente com a sua doença, com o seu tratamento, com o serviço ao qual está vinculado, com os profissionais de saúde envolvidos em seu tratamento, tudo isso pode ser considerado uma importante ferramenta para melhorar a adesão e permitir que 
os pacientes com co-morbidades tenham melhor adesão e menor abandono.

\subsubsection{Plano Individual de Adesão}

Os Projetos de Adesão, também chamados Programas de Tratamento Integral ou Plano Individual de Adesão, são estratégias consideradas bem-sucedidas, por auxiliar os pacientes e os profissionais de saúde na melhoria da adesão ao tratamento e na redução do abandono (HAYNES 1979 e RAND 1993). Nestes projetos, reitera-se:

A adesão compreende um programa extensivo ao comportamento da pessoa tomando medicação, seguindo uma dieta, e/ou realizando mudanças no estilo de vida estando a pessoa de acordo com as recomendações feitas pelo profissional de saúde.

O Projeto de Adesão preconizado pela Organização Mundial de Saúde (WHO 2001) consiste na organização de um planejamento individualizado para o tratamento, na perspectiva da realidade pessoal, dos limites e possibilidades do paciente. O acompanhamento individualizado e próximo entre profissional de saúde e paciente melhoram a possibilidade de aumento de adesão.

Essa estratégia foi desenvolvida para tratar ou controlar doenças crônicas em geral, mas pode ser considerada mais uma ferramenta de auxílio à melhoria da adesão para pacientes com aids, tuberculose e usuários de drogas.

A concepção de um Plano Individual de Adesão implica clareza ética e competência do profissional de saúde para uma anamnese acurada, com avaliação das condições mentais e do contexto de vida do paciente, para que ele seja capaz de discernir e participar de seu tratamento de modo mais ativo possível. Sendo individual, permite adequações constantes do tratamento ao dia-a-dia do paciente, com o mínimo de interferências em sua rotina ou, em caso de falta completa de rotina, o estabelecimento de parâmetros iniciais para intervenção.

O desenvolvimento de estratégias de adesão individualizadas exige também uma mudança de paradigma, do prescritivo para o dialogado. Isso pode ser angustiante ou mesmo impraticável para médicos e profissionais de saúde que tenham trabalhado toda a vida numa perspectiva de prescrições e compliance; seria um grande avanço sensibilizar estes profissionais para que, no mínimo, não rejeitem de imediato a idéia de que o paciente possa ter voz ativa, ver respeitados alguns de seus hábitos importantes e, portanto, possa 
aderir melhor ao tratamento (LIMA 2002b).

\subsubsection{Saúde Mental e Adesão}

As contribuições da Área de Saúde Mental para os trabalhos de adesão em HIV/Aids referem-se à anamnese clínica das condições cognitivas, emocionais e psicossociais dos pacientes. No Brasil, ainda não está implementado um protocolo para atenção de pacientes com distúrbios mentais portadores de HIV ou aids, tampouco uma anamnese psíquica específica para avaliação completa dos casos de pacientes com HIV ou aids, sendo utilizados os padrões da investigação em psicopatologia.

Considera-se que cada caso tenha um perfil psicológico a ser trabalhado, em que se verifique a condição de autonomia do paciente e a necessidade da presença de um cuidador, o grau de dependência em que se encontra o paciente, e a necessidade de intervenção em Saúde Mental com atendimento psicológico e/ou psiquiátrico propriamente ditos. No caso de usuários de drogas, o abuso de psicoativos é tratado com medicamentos e eventualmente reclusão, na perspectiva da abstinência preconizada pelas comunidades terapêuticas e psiquiatras. Nos serviços públicos, a estratégia de Redução de Danos ainda está sendo implementada, de modo tímido, não sendo a abordagem prioritária no atendimento de pacientes com dependência diagnosticada.

Nos casos de dependência de psicoativos, as estruturas familiares nem sempre estão disponíveis para se inserir um ‘cuidado médico’ para algum de seus membros. O cuidador não precisa ser alguém da família, mas alguém próximo e confiável, com quem o paciente sinta-se à vontade e que tenha o compromisso de cuidá-lo.

Segundo PALEPU et al (2004), os programas de tratamento de abuso de substâncias podem ser uma oportunidade para pessoas com HIV ou Aids com problemas de álcool e drogas abrir espaços para questões de tratamento do HIV, incluindo adesão a HAART ${ }^{4}$.

Em relação ao uso de álcool, estudos indicam que de fato prejudica a adesão a HAART, se o uso for feito nos 30 dias anteriores ao início do tratamento, e desencadeia sintomas depressivos. PALEPU et al (2004) ressaltam que a supressão viral está associada positivamente com altas doses de medicamento antiretroviral e idade acima dos 25 anos; e associada negativamente com uso de drogas ou álcool nos 30 dias anteriores.

\footnotetext{
${ }^{4}$ Highly Active Antiretroviral Therapy - Terapia Antiretroviral de Alto Impacto.
} 
INGERSOLL (2004) avaliou 120 adultos com HIV tomando anti-retrovirais, quanto ao esquema terapêutico, comportamentos de adesão, problemas mentais e padrões de uso de substâncias psicoativas. Em seu estudo, a não-adesão estava relacionada a uso recente de crack, cocaína e heroína, bem como fobia social, o que foi diferente de pesquisas anteriores, que traziam como referências a ansiedade, a depressão e o uso crônico de substâncias psicoativas como fatores predisponentes a não-adesão. No estudo de INGERSOLL1, são feitas duas recomendações

(a) a avaliação de não-adesão é melhorada utilizando-se múltiplos indicadores e

(b) a necessidade de vínculo estruturado do serviço de aids com os serviços de saúde mental para tratamento de abuso de substâncias e ansiedade, para (também) reduzir o risco de não-adesão.

Em relação aos pacientes usuários de drogas, os médicos ainda tendem a exigir a abstinência imediata, seja qual for a substância psicoativa utilizada (exceções feitas ao tabaco). Essa exigência, quando feita nas primeiras consultas, pode ter como argumentos, muitas vezes, uma interação farmacocinética que pode não existir, o perigo de overdoses e "males súbitos", que nem sempre existe, e poderá definir os rumos do abandono da terapia.

\subsubsection{A aconselhamento: conceito e importância na adesão}

Entende-se aconselhamento nos atendimentos às Doenças Sexualmente Transmissíveis e aids como o processo de abordagem do profissional de saúde para o paciente que deseja fazer o teste anti-HIV, que já fez o teste e segue aprimorando estratégias preventivas, ou mesmo pacientes em busca de orientação sobre outras áreas da saúde. Para o Ministério da Saúde, o aconselhamento é entendido como

processo de escuta ativa individualizado e centrado no cliente. Pressupõe a capacidade de estabelecer uma relação de confiança entre os interlocutores, visando ao resgate dos recursos internos do cliente para que ele mesmo tenha possibilidade de reconhecer-se como sujeito de sua própria saúde e transformação (MINISTÉRIO DA SAÚDE 2003).

O aconselhamento, na prática dos serviços de aids, é realizado por qualquer profissional de saúde. Educadores, sociólogos, psicólogos, dentistas, enfim, profissionais com as mais diversas formações específicas são considerados aconselhadores. 
O aconselhamento pré-teste anti-HIV pode ser realizado tanto em grupo como individualmente. No grupo, as pessoas têm a oportunidade de redimensionar suas dificuldades ao compartilhar dúvidas, sentimentos, conhecimentos, etc. Em algumas circunstâncias, essa abordagem pode aliviar o estresse emocional vivenciado pelos pacientes com a realização do teste. A dinâmica grupal também pode favorecer o indivíduo a perceber suas próprias necessidades, a reconhecer o que sabe e sente, o que pode incentivar sua participação nos atendimentos individuais subseqüentes.

Segundo o MINISTÉRIO DA SAÚDE (2003), alguns procedimentos básicos do aconselhamento estariam relacionados a adaptação da linguagem, orientações sobre as DST em geral e aids em particular, comportamentos de risco, importância da adesão. Neste documento do Ministério da Saúde sobre aconselhamento, não há diretrizes específicas para aconselhamento de pacientes co-infectados. Em relação à tuberculose, são necessárias orientações específicas para o tratamento e quimioprofilaxia, que não têm uma orientação padronizada nos serviços de DST/Aids pesquisados.

Os aconselhamentos pré e pós-teste anti-HIV estão detalhados no Anexo 1. São ferramentas importantes, pois são espaços para orientações diretas e objetivas sobre a doença tanto em relação aos seus aspectos técnicos (prevenção, mudanças necessárias de comportamento, etc.), quanto em relação ao seu impacto na vida do indivíduo e meio social em que vive, e as possíveis manifestações emocionais decorrentes do diagnóstico.

\subsubsection{Conceito de Saúde}

A saúde, na definição clássica e pós-Guerra da Organização Mundial de Saúde, é o 'completo estado de bem-estar físico, mental e social' (WHO 2001). Essa definição está incorporada no imaginário social contemporâneo, e muitas vezes a saúde é idealizada como um 'Nirvana', que será com mudanças comportamentais padronizadas, por exemplo, atingido quando o sujeito fizer todos os dias às $6 \mathrm{~h}$ da manhã uma caminhada matinal, controlar ingestão de gorduras, não ter qualquer 'vício'. Ou seja, para que o sujeito possa se considerar saudável, são necessárias tantas condições que talvez para ele jamais sejam atingíveis, que ele simplesmente desiste.

ALMEIDA (1998) aborda a perspectiva social do conceito de saúde: 
Saúde precisa ser entendida em sentido mais amplo, como componente da qualidade de vida. Não é um "bem de troca”, mas um "bem comum”, um bem e um direito social, em que cada um e todos possam ter assegurados o exercício e a pratica do direito á saúde.(...) Ou seja, deve considerar esse bem e esse direito como componente e exercício de cidadania.

O psiquiatra e psicanalista francês DEJOURS (1986) questiona o conceito da WHO e acrescenta: a saúde não é um estado, é um processo. Diz respeito às pessoas, e por elas deve ser coordenado; envolve uma constância de negociações, renúncias, decisões, o que implica em base de informações adequada. Para este autor, a saúde é muito mais do que a ausência de doenças, mas a liberdade do desejo. É considerada saudável aquela pessoa que, a despeito de sua condição orgânica, mantém seus sonhos e projetos significativos de vida, integra as dificuldades cotidianas a uma rotina de construção; em contrapartida, o sujeito biologicamente impecável, amortecido para a vida, ou totalmente restrito a um comportamento, é considerado doente.

A doença é historicamente vista como castigo, como maldição, como punição (BERLINGER 1996), e é um desafio para os profissionais de saúde conseguir a participação de seus pacientes em sua própria cura. Em se tratando de moléstias estigmatizadas, em que os pacientes sentem-se culpados, segregados e têm uma morte social inerente à revelação diagnóstica (DANIEL 1982), a realização de exames, a ingestão de medicamentos e a revelação do diagnóstico para o grupo social são processos áridos e que em geral os profissionais de saúde optam por aplicar prescrições que precisam ser seguidas. A Epidemiologia demonstra o conceito de multicausalidade como determinante das doenças e não apenas a presença exclusiva de um agente (ALMEIDA 1998) ou comportamento.

Ainda segundo ALMEIDA (1998), o fato é que se passa a considerar saúde e doença como estados de um mesmo processo, composto por fatores biológicos, econômicos, sociais e culturais. (....) Saúde e doença não são processos estanques, isolados, de causação aleatória. Há uma determinação permanente, um processo causal, que se identifica com o modo de organização da sociedade - e daí a se dizer que há uma “produção social da saúde e/ou da doença”, ou como diz Breilh (apud ALMEIDA 1998), “o processo saúde-doença constitui uma expressão particular do processo geral da vida 
social”.

Em termos práticos, pode-se destacar que em toda população há indivíduos sujeitos a fatores de risco para adoecer com maior ou menor freqüência e com maior ou menor gravidade. Há, portanto, grupos populacionais que exigem ações e serviços de natureza e complexidade variada. Isso significa que o objeto do sistema de saúde deve ser entendido como as condições de saúde da população e seus determinantes, visando produzir progressivamente melhores estados e níveis de saúde dos indivíduos e das coletividades, atuando articulada e integralmente nas prevenções primária, secundária e terciária, com redução dos riscos de doença, seqüelas e óbito (ALMEIDA 1998).

A aids, a tuberculose e o abuso de drogas atingem de modo diferente a diferentes segmentos populacionais, com impactos e seqüelas diversos. Um traço comum seria o agravamento desta condição tríplice pelo cenário de vulnerabilidade social e programática (AYRES 1999).

A forma de se compreender o processo saúde-doença é determinante na forma como o profissional de saúde atua em seu cotidiano, em especial os profissionais da Assistência. Há os profissionais que compreendem o tratamento como um processo mais amplo, em que a medicação é condição necessária, mas não suficiente para garantir a cura ou o desaparecimento/ melhoria dos sintomas - e para tanto, empenham-se na compreensão do universo do paciente e valorizam o trabalho em equipe multiprofissional.

Os profissionais não-médicos têm participação fundamental neste processo de assistência na saúde-doença, desde a revelação diagnóstica ao paciente até a facilitação da adesão. O paradigma médico-centrado, prescritivo, tem sido ampliado e vêm incorporando os conhecimentos específicos dos psicólogos, nutricionistas, assistentes sociais, educadores, com objetivo de oferecer o melhor tratamento possível aos pacientes.

A aids, dada a complexidade de seu tratamento, a longa duração e (até aqui) a impossibilidade de cura, requer estratégias inovadoras, planejadas, avaliadas para que os pacientes infectados pelo HIV tenham adesão. Os pacientes co-infectados com tuberculose também enfrentam longo e árido tratamento medicamentoso, porém com possibilidade concreta de cura. Os usuários de drogas nem sempre têm o estilo de vida caótico que lhes atribuem, porém merecem atenção especial pelas possibilidades de interação medicamentosa e co-morbidades psiquiátricas associadas, que necessitam correto 
diagnóstico. Trabalhar com esses pacientes com aids, tuberculose e usuários de drogas é um desafio ainda pouco explorado, em contraposição ao fato de apresentarem a possibilidade de adesão sempre questionada pelos profissionais de saúde.

O processo de intervenção, por meio de um sistema de cuidados para a saúde para atender as necessidades, demandas, aspirações individuais e coletivas, como um processo é político e técnico-científico: político no sentido de valores, interesses, aspirações e relações sociais e envolve a capacidade de identificar e privilegiar as necessidades de saúde individuais e coletivas resultantes daquele complexo processo de determinação e acumular força e poder para nele intervir, incluindo a alocação e garantia dos recursos necessários para essa intervenção; com necessária participação social, ou seja, a participação ativa da população na formulação, desenvolvimento e acompanhamento das políticas e dos sistemas de saúde- que hoje está minimamente estabelecida nos conselhos de saúde (municipal, estadual e nacional) e conferências de saúde; técnico e científico no sentido que esse saber e esse fazer em relação à saúde-doença da população não devem ser empíricos, mas podem e devem ser subsidiados pelo conhecimento científico e desenvolvimento tecnológico, pelo avanço e progresso da ciência (ALMEIDA 1998). 


\subsection{SÍNDROME DA IMUNODEFICIÊNCIA ADQUIRIDA - aids ${ }^{5}$}

Desde a primeira descrição da síndrome da imunodeficiência humana - aids - em 1981, pesquisadores identificaram dois tipos de Vírus da Imunodeficiência Humana (HIV), o HIV-1 (predominante em todo o mundo e também no Brasil) e o HIV-2 (que ocorre mais comumente no oeste da África). Os dois tipos de vírus causam aids e as formas de transmissão são as mesmas, vias sexual e sangüínea. Porém, a transmissão do HIV-2 é mais complexa e a sua progressão é mais lenta.

\subsubsection{Epidemia de aids no Brasil: breve histórico e tendências atuais.}

A epidemia de aids foi amplamente divulgada nos meios de comunicação de massa em seu início, na década de 80, mas atualmente seu papel na mídia está reduzido a informes estatísticos sobre remédios ou incidência. Sendo uma epidemia dinâmica, inconstante, fluida, essa redução anunciada tem como reflexo uma idéia no imaginário social que a aids está sob controle, com tratamentos simples ("coquetel” sugere "coquetel de frutas") e com as estratégias de prevenção já incorporadas ao comportamento de todas as pessoas (LIMA 2000).

Ainda segundo LIMA (2000), no início da década de 80, o registro de casos era nitidamente superior na população da classe média, homossexual masculina e usuários de drogas injetáveis, posteriormente, disseminou-se - a chamada pauperização - e passa também a atingir as mulheres em altíssima proporção - a feminização, tendência que se mantém até a atualidade.

Segundo ZAMPIERI (1996), a aids seria um conjunto de várias subepidemias, com forte sobrecarga física e emocional para os doentes e os profissionais de saúde. O adoecimento teria duas concepções fundantes: uma quase metafísica, religiosa, culpabilizante (derivada do judaico-cristianismo) e outra, racional e pragmática.

As contradições e os desencontros, bem como a doença, entram no âmbito do que seria o destino. Não há nada a fazer quando se acredita que 'o que tem que acontecer, acontece'. O conceito de destino impossibilita a prevenção e o tratamento (MARTIN

\footnotetext{
${ }^{5}$ O Programa Nacional de Doenças Sexualmente Transmissíveis e Aids, por meio de sua Assessoria de Comunicação Institucional, recomenda que a grafia da palavra aids seja em caixa baixa, exceto em início de frases e na seqüência da sigla DST (2005). Deixou de ser uma sigla e passou a representar uma doença. Disponível em <URL:http://www.aids.gov.br>.
} 
1995).

A questão dos chamados 'grupos de risco' também é importante para análise do impacto da aids na sociedade contemporânea. MICHALIZEN (1999) relembra que o conceito de 'grupos de risco' já fazia parte do discurso epidemiológico antes mesmo do surgimento da aids.

A Epidemiologia sempre teve como primeiro procedimento, ante uma doença, a identificação dos agentes etiológicos, definição dos grupos ou subgrupos populacionais onde se observa maior incidência de casos para se estabelecer barreiras à sua disseminação. E relação à aids, a noção de 'grupos de risco' tomou grandes proporções no imaginário social, aliando grupos previamente segregados na sociedade a uma doença ainda desconhecida. A segregação sequer era disfarçada, como se os acometidos pela doença fossem responsáveis por seu surgimento e disseminação, com a seguinte base: (...) em junho de 1981, quando nos Estados Unidos foram detectados os primeiros casos da doença em homossexuais, imediatamente surgiu o primeiro conceito de grupo de risco para aids, o que por sua vez motivou e proporcionou, por parte da população, várias atitudes de revolta e preconceito, culminando, muitas vezes, em morte e violência contra estes, por parte da sociedade (PARKER 1994).

Perpetua-se, no imaginário social, a incompreensão ou a falta de clareza de quem está em risco de pegar aids e quem não está. A divisão em grupos dificultou elaboração de ações conjuntas em resposta à epidemia, o que reforça a divisão social, o aumento de maustratos a grupos estigmatizados. E, finalmente, a concentração de recursos da saúde pública especificamente na aids quando ignoram a natureza social da doença (MARTIN 1995).

Atribuindo-se a responsabilidade social pela disseminação da epidemia a esses grupos, houve estímulo à discriminação e à violência (MICHALIZEN 1999). Foi assim que o conceito de 'grupos de risco' acabou por servir como forte motivo para discriminar portadores de HIV e doentes tendo a epidemiologia como pretexto.

Segundo o MINISTÉRIO DA SAÚDE (2005a), a aids no Brasil hoje tem incidência de 19,2 casos por 100 mil habitantes e mortalidade estabilizada em cerca de 11 mil óbitos anuais desde 1998. As principais tendências observadas são as seguintes:

a) Feminização: em 1986, apenas 5\% dos casos notificados eram do sexo feminino. Passou para cerca de 30\% em 1999. Em 2005, são 15 casos por 100 mil mulheres, com 
crescimento persistente em todas as faixas etárias exceto $13-24$ anos, em que permanece estável. De uma proporção de 28 homens para uma mulher infectada em 1985, essa proporção cai para três para um em 1996/1997 e em 2005, a proporção de 1,5 homem para uma mulher infectada (para cada 15 casos masculinos existem 10 casos femininos).

b) Heterossexualização: houve um aumento significativo dos casos dentro da subcategoria de exposição heterossexual, que representava menos de $5 \%$ dos casos notificados. Ao longo da epidemia, passou a ser a principal subcategoria de exposição em crescimento: homens e mulheres heterossexuais, em relações chamadas 'estáveis', ou seja, com parceiros ditos monogâmicos.

c) Interiorização: inicialmente, os casos de aids situavam-se em áreas restritas às grandes metrópoles de Sul e Sudeste do país. Até 2004, 4.165 dos 5.560 - ou seja, 74,9\% dos municípios brasileiros já apresentaram pelo menos um caso de aids notificado.

d) Pauperização: até 1982, a totalidade dos casos diagnosticados era atribuída a um nível de escolaridade superior ou de ensino médio (antigo segundo grau). A partir daí verificouse uma tendência de aumento de registro de pacientes com menor grau de escolaridade. Em 1995, constatou-se que $31 \%$ dos casos pertenciam a esse grupo, e destes, $69 \%$ eram analfabetos ou tinham cursado o ensino fundamental (antigo primeiro grau).

Pela tendência observada no Brasil, as populações tradicionalmente marginalizadas, sobre as quais recaem a grande maioria das doenças endêmicas e as patologias agravadas pela fome e precariedade de condições de vida, vêm cada vez mais se infectando pelo HIV - o que torna compreensível a alta prevalência da co-infecção por tuberculose.

\subsubsection{Definição de casos de aids}

A primeira definição de caso de aids adotada pelo Ministério da Saúde do Brasil foi em 1987, restrita aos indivíduos com quinze anos de idade e mais. Desde então, segundo o MINISTÉRIO DA SAÚDE (2003), a definição de casos de aids em adultos no Brasil passou por sucessivas revisões que tiveram como objetivo principal a adequação dos critérios às condições diagnósticas e laboratoriais e ao perfil da morbidade do País. A evolução das definições de caso de aids acompanha os avanços tecnológicos e sua disponibilidade. A primeira definição de caso de aids no mundo foi estabelecida pelo Centers for Disease Control and Prevention (CDC) dos Estados Unidos da América em 
setembro de 1982. A atual revisão data de 2004 e define os casos de aids em adultos maiores de 13 anos (Código CID 10:B24) e está resumida no quadro abaixo:

Quadro 1. Critérios de definição de casos de aids no Brasil em indivíduos com 13 anos ou mais. Ministério da Saúde, 2003.

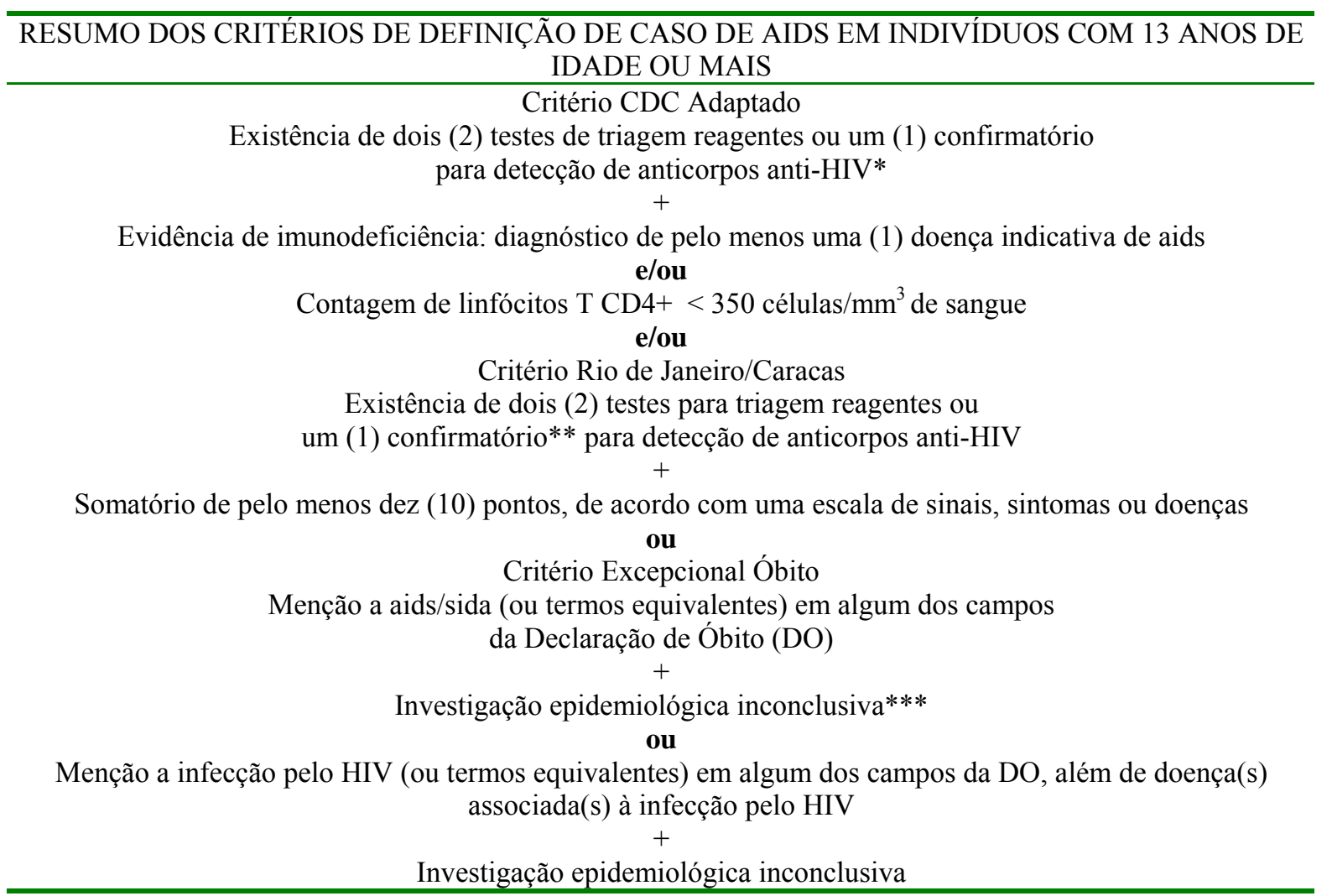

Fonte: Ministério da Saúde, 2003.

Notas explicativas:

* São testes de triagem para detecção de anticorpos anti-HIV: várias gerações de ensaio por imunoabsorbância ligado à enzima (Enzyme Linked Imunnosorbent Assay, ELISA), ensaio imunoenzimático (Enzyme Immuno Assay, EIA), ensaio imunoenzimático com micropartículas (Microparticle Enzyme Immuno Assay, MEIA) e ensaio imunoenzimático com quimioluminescência.

** São testes confirmatórios: imunofluorescência indireta, imunoblot, Western Blot, teste de amplificação de ácidos nucléicos como, por exemplo, a reação em cadeia da polimerase (Polimerase Chain Reaction, PCR) e a amplificação seqüencial de ácidos nucléicos (Nucleic Acid Sequence Based Amplification, NASBA).

*** Define-se como investigação epidemiológica inconclusiva aquela em que, após a busca de prontuários, o caso não for descartado ou enquadrado num dos critérios, pelo não registro de dados clínicos/laboratoriais. 


\subsubsection{História natural da infecção pelo Vírus da Imunodeficiência Humana (HIV): infecção e evolução para casos de aids}

As formas de contágio pelo HIV conhecidas e com importância epidemiológica são as relações sexuais desprotegidas, transfusão de sangue, transmissão da mãe para o feto (transmissão vertical) na hora do parto ou na amamentação (MINISTÉRIO DA SAÚDE, 2005b). A partir deste, existe um período ainda desconhecido de tempo em que o vírus não se manifesta, em que os testes anti-HIV são negativos e apresentam resultado positivo somente em torno de 4 a 12 semanas após a infecção. Mais de 95\% dos pacientes realizam a soroconversão cerca de seis meses após a transmissão (RACHID e SCHECHTER 2003).

Após a soroconversão, o vírus permanece no organismo, de modo ainda não perfeitamente conhecido, durante um período latente longo e variável, e em determinado momento começa a se reproduzir, dizimando os glóbulos brancos, em especial os linfócitos, permitindo que quaisquer microorganismos, até mesmo da flora normal do corpo, destruam tecidos e provoquem infecções (denominadas oportunistas) que caracterizam o quadro de aids. Ainda segundo RACHID e SCHECHTER (2003, uma pessoa adulta infectada com HIV pode ficar assintomática por dez anos ou mais.

A infecção aguda pelo HIV é chamada "infecção primária pelo HIV" ou "síndrome da soroconversão".

$\mathrm{Na}$ grande parte das pessoas infectadas pelo HIV e sem tratamento desenvolve-se co-infecção ou doença associada ao HIV e aids. Alguns indivíduos progridem mais rapidamente que outros, e a razão da progressão depende de características do vírus e do hospedeiro. As características do vírus incluem tipo e subtipo: HIV-1 e seus subtipos certamente provocam progressão mais rápida. As características do hospedeiro que podem causar progressão mais rápida incluem idade inferior a 5 anos ou superior a 40, infecções concomitantes e fatores genéticos (RACHID e SCHECHETER 2003).

Com o avanço da infecção pelo HIV e declínio da imunidade, os pacientes tornamse mais suscetíveis a infecções como a tuberculose, a pneumonia, as infecções causadas por fungos, dentre outras. Essas infecções podem ocorrer em qualquer estágio da progressão da infecção pelo HIV e muitos pacientes desenvolvem sintomas chamados constitucionais (febre inexplicada, perda de peso, diarréia crônica). 


\subsubsection{Tratamento da aids}

Em 1992 são criados no Brasil diversos serviços públicos de assistência em HIV/Aids, como o Serviço Ambulatorial Especializado (SAE), o Hospital-Dia (HD), e a Assistência Domiciliar Terapêutica (ADT), para ações de controle das DST/Aids no país (LIMA 2000).

O anúncio da terapia combinada em Vancouver, em 1996, teve grande impacto no Brasil, entre os pacientes que vislumbravam algum tratamento além do AZT, e entre os profissionais de saúde, com necessidade de atualização do conhecimento técnico-científico para prescrever os remédios. Ainda segundo LIMA (2000), uma das repercussões mais negativas do anúncio precipitado de 'cura' foi a supervalorização da terapia combinada, porque esta palavra, a despeito de ter sido incontáveis vezes desmentida, ficou diretamente vinculada ao conceito de 'carga viral indetectável' e ao denominado "coquetel".

Os pacientes já infectados e os não-infectados pelo HIV tiveram um 'relaxamento' na prevenção, com redução no uso de preservativos e comportamentos preventivos, em função da idéia de 'cura' advinda da divulgação dos medicamentos anti-retrovirais combinados (LIMA 2000).

\section{a) Princípios do tratamento ARV}

O primeiro aspecto importante no que se refere a tratamento de aids no Brasil é a disponibilização do tratamento na rede pública de saúde. De acordo com a Lei n ${ }^{0}$ 9313/96 (MINISTÉRIO DA SAÚDE 2000b), é da responsabilidade do Governo a disponibilização do tratamento mais adequado aos pacientes infectados pelo HIV, dentro de parâmetros técnicos e científicos definidos pelo Ministério da Saúde, por intermédio do Programa Nacional de DST e Aids.

Segundo o MINISTÉRIO DA SAÚDE (2005b), a TARV, em indivíduos com infecção estabelecida pelo HIV, não é considerada uma emergência, e não deve ser iniciada

\footnotetext{
6 A lei 9313/96, que garantiu o acesso universal e gratuito aos medicamentos para aids no Brasil. Essa legislação, aprovada logo após a descoberta dos 'coquetéis', reduziu em mais de $50 \%$ as mortes por aids no país; provocou um impacto mínimo na previdência social (apenas 0,1\%) e evitou mais de 234 mil internações por doenças oportunistas no período 97/2000, o que corresponde a uma economia de 677 milhões de dólares. Essa economia é o dobro do gasto anual que o governo brasileiro tem com a compra e a produção dos antiretrovirais (url:http://www.aids.gov.br).
} 
antes que as devidas avaliações clínica e laboratorial sejam realizadas para determinar o grau de imunodeficiência já existente e o risco de progressão. No Consenso para Tratamento de adultos e adolescentes, o governo também recomenda:

A terapia não deve ser iniciada até que os objetivos e a necessidade de adesão ao tratamento sejam entendidos e aceitos pelo paciente.

Segundo a Organização Mundial de Saúde (WHO 2004), o tratamento com antiretrovirais (TARV), introduzido em 1996, reduziu bruscamente a letalidade das pessoas infectadas pelo HIV. A terapia de alto impacto - $\mathrm{HAART}^{7}$-, é uma combinação de drogas utilizada como 'standard', recomendada para todos os pacientes em início de tratamento. As drogas ARV pertencem a duas classes, os inibidores da transcriptase reversa e os inibidores de protease, em função de seu mecanismo de atuação.

Com a disponibilização dos medicamentos seguindo os princípios do SUS de universalidade (todos têm direito e acesso), dois aspectos importantes a se refletir são o momento de início da terapia e os critérios para mudança de esquema terapêutico. Estes, devem ter como base a condição clínica e imunológica do paciente, e não uma resposta imediata às queixas acerca dos efeitos colaterais.

Segundo o MINISTÉRIO DA SAÚDE (2005b), a monoterapia, ou administração de um único tipo de medicamento, não é recomendada porque facilita a resistência medicamentosa, embora haja recomendação específica de sua utilização para prevenir a transmissão de mãe para filho (transmissão vertical). A terapia dupla também não é recomendada porque, além de não ter a mesma eficácia da terapia tripla, evolui mais rapidamente para falha.

A recomendação do Ministério da Saúde é que todos os pacientes que estejam em terapia dupla, mesmo os que se encontram estáveis clínica, imunológica e virologicamente, sejam reavaliados (MINISTÉRIO DA SAÚDE 2005b) para possibilidade de introdução de terapia tripla.

Segundo o Consenso de 2005 (MINISTÉRIO DA SAÚDE 2005b), a modificação do esquema duplo para triplo deve considerar, antes de tudo, se a carga viral está indetectável, além do potencial de adesão ao novo esquema.

\footnotetext{
${ }^{7}$ Highly Active Antiretroviral Therapy também denominado esquema anti-retroviral potente.
} 
Ainda segundo a recomendação do MINISTÉRIO DA SAÚDE (2005b), no caso da carga viral detectável, a troca deve ter como base o perfil de resistência de cada droga e de resistência cruzada entre drogas da mesma classe. Quando possível, deve ser realizado o exame de genotipagem do HIV.

Em 2005, o Comitê Assessor para diretrizes técnicas de tratamento de HIV e aids (MINISTÉRIO DA SAÚDE 2005b) estabeleceu parâmetros para o que seria considerado, no Brasil, como inaceitável em termos de tratamento de HIV e aids, listados abaixo:

- Monoterapia;

- Qualquer terapia dupla inicial, exceto em quimioprofilaxia pós-acidente;

- $\quad$ AZT + d4T;

- $\quad$ D4T + ddI na gestação;

- Efavirenz na gestação;

- Indinavir + saquinavir;

- Amprenavir não-associado a ritonavir;

- Saquinavir não-associado a ritonavir;

- Dois ou mais ITRNN;

- $\quad$ Esquema de três ou mais ITRN não combinados a outras classes, exceto AZT (ou d4T) + $3 \mathrm{TC}+\mathrm{ABC}$ em situações especiais*;

- $\quad$ Tenofovir + ddI + ITRNN não combinados a IP.

*Devido à maior potência, maior risco de falha e de desenvolvimento de ampla resistência cruzada em curto prazo, este esquema é contra-indicado e seu uso somente pode ser considerado para pacientes em tratamento de tuberculose com rifampicina e com impossibilidade de uso de efavirenz. Outra exceção é a hepatopatia grave em que haja contra-indicação a esquemas com IP ou ITRNN.

\section{b) Início do tratamento}

Os médicos divergem acerca do momento de introdução da terapia combinada: um grupo defende a idéia de introdução dos medicamentos anti-retrovirais logo após o diagnóstico do HIV, independentemente da carga viral e do índice de linfócitos T-CD4+ (o chamado "bata cedo e bata forte"), enquanto outro grupo defende o que é preconizado nas diretrizes oficiais, considerando o início da terapia apenas como o momento em que o paciente, em seus exames clínicos e laboratoriais, atinge o "índice-limite de CD4 e carga viral, frente a um adoecimento inicial" (MINISTÉRIO DA SAÚDE 2005b). 
Para o paciente surge a expectativa, após o diagnóstico de HIV+, quando e se haverá início o tratamento medicamentoso, se e quando terá doenças oportunistas, quais os efeitos colaterais, seus direitos reprodutivos - dentre outros temas -, o que pode ser motivo de grande ansiedade e fonte de sofrimento.

\section{c) Adesão ao tratamento da aids}

A questão da adesão ao tratamento da aids passou a compor os trabalhos de intervenção na área de HIV/Aids a partir do anúncio do 'coquetel', em 1996: o grande número de comprimidos a ser ingeridos por dia, bem como as diversas exigências de horários, temperatura do comprimido, condição gástrica/nutricional do paciente, as deformidades corporais pela lipodistrofia, tudo isso começou a dificultar o oásis prometido pelo 'coquetel' (LIMA 2000).

As pesquisas divulgadas em Vancouver em 1996 sobre os primeiros pacientes submetidos à terapia combinada traziam os seguintes dados: "dos doze pacientes recrutados, três deles acabaram abandonando o tratamento" (HO et al 1996). Não foram discutidos ou apresentados os motivos dos abandonos e apenas destacadas as reduções das cargas virais dos nove pacientes que permaneceram em tratamento, porém é sabido que uma das conseqüências do uso incorreto da medicação anti-retroviral é o desenvolvimento de linhagens de HIV resistentes. Só no Brasil, haveria pelo menos três subtipos do HIV já catalogados, denominados B, E e F (KNECHTEN 1999) e essa informação não é divulgada para a população.

Ainda segundo LIMA (2000), os pacientes soropositivos para HIV, ignorando essa possibilidade de reinfecção por linhagens resistentes ou diferentes subtipos, reduzem o uso de preservativos e mantêm relações sexuais desprotegidas com parceiros igualmente soropositivos, o que representa um problema de saúde pública com grande impacto na história natural da doença, em especial na etiopatogenia do HIV, para a qual ainda não existe prevenção sistematizada.

O conhecimento das causas da não adesão deve se reverter em uma política melhor adequada e ganho para os pacientes que, entre outros benefícios, evitarão a resistência dos agentes infecciosos. 
Em relação às interações medicamentosas, é importante que o paciente seja indagado acerca de uso concomitante dos ARV com outros medicamentos, prescritos ou não, inclusive fitoterápicos e outros produtos usados em 'terapias alternativas', e orientado sobre os riscos de toxicidade e mesmo possível perda da eficácia dos ARV.

Nas interações de fármacos e psicoativos, ENGELKE e MORAES (2005) avaliam cada um dos medicamentos anti-retrovirais e destacam o papel do álcool no aumento dos níveis séricos. O álcool também interfere no aumento de risco de eventos adversos com a formulação oral do amprenavir. Os autores também descrevem as interações dos antiretrovirais entre si, e termos de efeitos colaterais e contra-indicações de usos concomitantes.

Estas informações, caso tenham ampla divulgação para todos os profissionais de saúde, médicos e não-médicos, podem auxiliar na compreensão do real papel do álcool nas interações medicamentosas com ARV.

\section{d) Adesão e Mudança de Esquema ARV}

Antes de se considerar definitivamente que houve falha terapêutica por resistência viral e prosseguir uma mudança do esquema terapêutico, é importante certificar-se de que o paciente está realmente fazendo uso dos medicamentos na posologia adequada. Os profissionais de saúde no Brasil avaliam a adesão combinando auto-relato dos pacientes, resultados clínicos e laboratoriais e a percepção pessoal (MINISTÉRIO DA SAÚDE 2005b).

Ainda segundo o MINISTÉRIO DA SAÚDE (2005b), diversos problemas de adesão relacionados aos hábitos de vida, interrupções para uso de álcool e outras drogas, efeitos colaterais, toxicidade e/ou interações medicamentosas podem interferir na manutenção de níveis adequados das drogas ARV no sangue e prejudicar o tratamento. Considera-se fundamental o trabalho da equipe multiprofissional na detecção e encaminhamento desses problemas. Os pacientes podem confidenciar seu comportamento para um profissional e não para outro, em função da empatia pessoal, dentre outros fatores.

As opções terapêuticas ainda são limitadas e a decisão de modificar o esquema de tratamento invariavelmente restringirá as opções futuras. Além disso, qualquer esquema administrado a pacientes não-virgens de terapia está associado a uma menor taxa de 
resposta virológica que a esperada em esquemas inaugurais (MINISTÉRIO DA SAÚDE, 2005b).

Antes de optar-se por mudança de esquema terapêutico, deve-ser avaliar o estágio da infecção pelo HIV, as opções disponíveis para estabelecer um esquema de resgate, a chance de adesão daquele paciente a esquemas complexos e a chance do novo esquema trazer ganhos em relação às respostas virológica e/ou imunológica. Para todos os pacientes, recomenda o MINISTÉRIO DA SAÚDE (2005b) que a escolha do esquema de resgate deve considerar os medicamentos já utilizados, a possível resistência cruzada de ARV e a chance do paciente aderir ao novo esquema.

$\mathrm{Na}$ falha de tratamento, o ideal é a troca completa de esquema, incluindo-se, sempre que possível o uso de drogas ARV pertencentes a classes terapêuticas ainda não utilizadas pelo paciente. Caso não seja possível, preconiza-se que o novo esquema deva ter, pelo menos, duas drogas não utilizadas anteriormente.

\section{e) Genotipagem do HIV}

O Programa Nacional de DST e Aids do Ministério da Saúde implantou uma Rede Nacional para executar e interpretar testes de genotipagem, conhecida como Rede Nacional de Genotipagem (RENAGENO), com objetivo de detectar a ocorrência de resistência genotípica do HIV-1 aos ARV e selecionar a terapia de resgate mais adequada aos pacientes atendidos no SUS (LIMA 2000). Esta rede foi implantada como uma 'pesquisa operacional', cujos critérios de inclusão, avaliação e acompanhamento foram estabelecidos por comitê técnico, e conta com laboratórios capacitados e médicos treinados para orientar na interpretação do teste de genotipagem (médicos de referência em genotipagem). Para realização da genotipagem pela RENAGENO, os critérios são os seguintes:

1. Primeira falha com terapia dupla;

2. Primeira falha com terapia tripla contendo ITRNN

3. Primeira ou segunda falha com IP;

4. Carga viral acima de 5.000 cópias $/ \mathrm{ml}$.

É essencial que a coleta de sangue para teste de genotipagem seja realizada na vigência de terapia, isto é, o esquema de $\mathrm{ARV}$ em uso não deve ser interrompido e a necessidade de adesão nas semanas anteriores à coleta deve ser enfatizada. Muitos casos de 
não-detecção de mutações de resistência se devem à volta do predomínio de vírus selvagem que ocorre após um período de interrupção do uso da droga.

\section{f) Caracterização da Falha Terapêutica}

A falha de um esquema ARV é definida pelo Ministério da Saúde (2005b) como a ocorrência de deterioração clínica e/ou piora dos parâmetros laboratoriais imunológico e/ou virológico. Entretanto, o conceito é complexo e requer análise dos fatores associados e eventuais exceções.

A ocorrência de infecção oportunista é, na maior parte das vezes, indicador de falha terapêutica. Entretanto, quando o tratamento é iniciado já na vigência de um quadro de imunodeficiência avançada, o aparecimento da infecção oportunista pode não estar associado à falha terapêutica, mas sim à persistência da imunossupressão.

A falha de resposta ao esquema terapêutico pode ocorrer por diferentes motivos, sendo alguns deles:

- doença muito avançada;

- presença de co-morbidades;

- resistência viral prévia a um ou mais agentes;

- absorção gastrointestinal alterada;

- interações medicamentosas;

- potência baixa do esquema ARV;

- não-adesão ao tratamento.

Quando possível, a causa da falha deve ser identificada e corrigida. Considera-se a adesão inadequada a causa mais freqüente de falha do tratamento, pois o uso dos medicamentos em doses subótimas ou de forma irregular acelera o processo de cepas virais resistentes.

Do ponto de vista laboratorial, os principais parâmetros que sugerem falha terapêutica são: a elevação da carga viral e/ou redução significativa da contagem de linfócitos T-CD4+. A recomendação é que não se deve modificar o esquema terapêutico com base em um único exame que tenha mostrado essa queda de linfócitos. No caso de pacientes assintomáticos em uso contínuo e adequado de ARV, deve-se considerar pelo menos dois exames. 
Ao ser diagnosticada a falha terapêutica, deve-se avaliar as falhas virológica, imunológica e clínica - que geralmente não têm evolução simultânea, sendo primeiro a falha virológica, depois a imunológica, e por último a clínica. O intervalo entre elas pode ser de meses ou anos, o que explica em muitos casos a elevação da carga viral sem queda concomitante da contagem de linfócitos.

No caso de pacientes com extensa experiência com drogas ARV, nos quais a supressão completa da carga viral é difícil de ser obtida, alguns estudos mostram que a contagem de linfócitos T-CD4+ é o melhor indicador da resposta terapêutica, devendo, preferencialmente, ser monitorada após curtos intervalos de tempo para eventual modificação do esquema.

Em síntese, a aids tem tratamento subsidiado pelo Governo Federal, parâmetros para definição de casos, definição de eficácia e abandonos, recomendações específicas que podem contribuir para a implementação de um Plano Individual de Adesão para que os pacientes melhorem a adesão e reduzam o abandono. 


\subsection{TUBERCULOSE}

A tuberculose é uma das mais antigas doenças conhecidas e estudadas da humanidade. É conhecida como uma doença transmissível e também pelo fato de ser uma doença que acomete organismos debilitados, como os alcoolistas, as pessoas desnutridas e as submetidas a condições de confinamento. Não é um simples problema de saúde do indivíduo, é um grave problema de saúde pública no Brasil e em vários outros países. Foi a principal causa de morte na Europa e nos Estados Unidos até o início do século XX, e requer grandes esforços coletivos para mudança dos padrões endêmicos. (MINISTÉRIO DA SAÚDE, 2002b)

Em comum com a aids, a tuberculose tem, no imaginário social, o rótulo estigmatizante. $\mathrm{O}$ doente de tuberculose, mesmo antes do advento do tratamento com quimioterápicos, era segregado - mesmo com cerca de $25 \%$ de cura espontânea - e ainda assim permanece. Pessoas com tuberculose, mesmo em pleno século XXI, temem revelar seus diagnósticos, com medo de perder o emprego, medo do preconceito por parte dos familiares e amigos, e ainda prevalece a falta de informações acerca das formas de contágio, tratamento e profilaxia.

Ao contrário da aids, a tuberculose não conta com Organizações NãoGovernamentais fortes e participativas no controle da doença. O Programa Nacional de DST/Aids não mantém um fluxo informativo, compartilhamento de registro epidemiológico e padronização de estratégias preventivas com o Programa Nacional de Controle da Tuberculose.

Não há justificativa plausível para as pessoas continuarem morrendo hoje de tuberculose, uma doença que tem etiopatogenia, diagnóstico e tratamento conhecidos e divulgados. Neste ítem, serão apresentados alguns aspectos básicos da doença tuberculose e seu tratamento preconizado pelo Ministério da Saúde.

\section{a) Epidemiologia}

Estima-se que o M. tuberculosis infecte 1/3 da população mundial. Em 2000, eram estimados 8,3 milhões de novos casos de tuberculose no mundo. Segundo a WHO (2004), cerca de $75 \%$ dos casos de tuberculose nos países em desenvolvimento estão na faixa etária economicamente produtiva ( 15 a 50 anos). A porcentagem de pacientes adultos com tuberculose que têm HIV é de $12 \%$. 
Os dados epidemiológicos de tuberculose no Brasil até 1996 são os seguintes:

Tabela 1. Incidência de tuberculose no Brasil até 1996. Brasil, 2000.

\begin{tabular}{lll}
\hline ANO & Casos Notificados & Incidência \\
\hline 1985 & 84.310 & 64,6 \\
1986 & 83.731 & 63,0 \\
1987 & 81.806 & 60,4 \\
1988 & 82.395 & 58,5 \\
1989 & 80.375 & 57,1 \\
1990 & 74.570 & 52,0 \\
1991 & 84.990 & 57,8 \\
1992 & 85.955 & 57,6 \\
1993 & 75.453 & 54,0 \\
1994 & 75.759 & 47,6 \\
1995 & 91.013 & 58,6 \\
1996 & 85.860 & 54,7 \\
\hline FONTE: Fundação Nacional de Saúde/Ministério da Saúde
\end{tabular}

Quadro 2. Situação da tuberculose no Brasil no ano 2000.

\begin{tabular}{|l|}
\hline \multicolumn{1}{|c|}{ SITUAÇÃO DO BRASIL NO ANO 2000} \\
$\cdot \mathrm{N} .{ }^{\mathrm{o}}$ de casos estimados $(\mathrm{WHO})=124.000$ \\
$\cdot \mathrm{N} .{ }^{\mathrm{o}}$ de casos notificados em $1999=78.628$ \\
$\cdot$ Coeficiente de incidência $(1999)=48,0 / 100.000$ \\
$\cdot \mathrm{N} .{ }^{\mathrm{o}}$ de óbitos $(1998)=5.879$ \\
$\cdot$ Coeficiente de mortalidade $(1998)=3,5 / 100.000$ \\
$\cdot$ Percentual de detecção de casos $=67 \%$ \\
$\cdot$ Percentual de curas observado $=72 \%$ \\
$\cdot$ Percentual de abandono $=12,1 \%$
\end{tabular}

Fonte: PN DST/Aids, 2005.

\section{b) Etiopatogenia}

O agente causador da tuberculose humana é o $M$. tuberculosis, e ocasionalmente $M$. bovis e, mais raramente, M. africanum. Descoberto em 1882 por Robert Koch, é uma micobactéria com a característica de ser aeróbio estrito, capaz de sobreviver no interior de células fagocitárias e se multiplica a cada 18 a 24 horas. É um bacilo ${ }^{8}$ muito resistente a agentes químicos (decorrência da parede celular rica em lipídios), mas extremamente

${ }^{8}$ Chamado bacilo álcool-ácido-resistente (BAAR) por sua característica para identificação em laboratório. 
sensível ao calor e à radiação ultravioleta.

c) Transmissão: a transmissão da tuberculose se faz por via aerógena, com partículas ou gotículas $^{9}$ de secreção. A fonte de infecção habitual é o indivíduo com forma pulmonar da tuberculose, eliminando bacilos para o exterior (MINISTÉRIO DA SAÚDE, 2002).

Calcula-se que, durante um ano, numa comunidade, uma pessoa que seja fonte de infecção poderá infectar, em média, de 10 a 15 pessoas que com ela tenham tido contato. A intensidade do contato é uma das condições que fazem com que a tuberculose esteja associada à população de baixa renda, pois as famílias são numerosas e convivem muito proximamente em casas pequenas, mal ventiladas e úmidas. A fala, o espirro e a tosse de um doente com tuberculose pulmonar lançam no ar gotículas contaminadas de tamanhos variados, que dispersam o agente etiológico.

\section{d) $O$ processo de infecção e adoecimento em tuberculose}

Se o bacilo que foi inalado conseguir ultrapassar os mecanismos de defesa do organismo e alcançar os alvéolos pulmonares, provoca uma rápida resposta inflamatória, sem lesão visível. Pode haver uma progressão no processo inflamatório e broncopneumonia inespecífica. Com isso, o bacilo começa a se dividir e a aumentar em número no foco da inoculação. Ao fim de 15 dias de replicação, o número de bacilos aumenta e pode resultar em disseminação por via linfática ou hematogênica (MINISTÉRIO DA SAÚDE 2002b). O foco pulmonar é chamado foco de Ghon, e seu período de tempo para seu desenvolvimento é de três a quatro semanas. No momento de disseminação hematogênica, o organismo, já com a imunidade adquirida desenvolvida, impede o estabelecimento de tuberculose doença em 95\% dos casos, encerrando a chamada primoinfecção.

Em cerca de 95\% das lesões pulmonares iniciais, os focos de Gohn evoluem para fibrose e/ou calcificação, observáveis em exames radiológicos. Em 5\% destes, entretanto, a primoinfecção não é contida, por falha na imunidade celular, carga infectante elevada ou alta virulência dos bacilos aspirados, e há desenvolvimento da doença. Cerca de $90 \%$ permanecem infectados pelo resto da vida.

Conceitualmente, a tuberculose resultante da progressão do complexo pulmonar primário que se desenvolve nos primeiros cinco anos após a primoinfecção é chamada de

\footnotetext{
${ }^{9}$ Perde carga de água e fía na forma de Núcleo de Weiss, resistente e infectante, que é a gotícula desidratada (MINISTÉRIO DA SAÚDE, 2002). Gotículas medindo 5 micra (que contêm 1 a 4 bacilos).
} 
tuberculose primária.

A infecção tuberculosa é detectada apenas pela prova tuberculínica, ou seja, a única evidência de sua infecção é o resultado positivo ao teste tuberculínico. A grande maioria (95\%) das pessoas sem infecção pelo HIV que são infectadas com $M$. tuberculosis não desenvolvem tuberculose.

O risco de infecção depende de uma série de fatores facilitadores:

- Confinamento em prisões, asilos e hospitais: pode contribuir para a difusão da doença, não apenas entre as populações-alvo, mas entre os profissionais de saúde;

- Contatos de casos de tuberculose; abuso de álcool, uso de drogas; ser morador de rua; diabetes mellitus (DM); infecção pelo HIV;

- Tratamento prolongado com corticosteroídes (em particular pacientes em hemodiálise); indivíduos portadores de seqüelas pulmonares de tuberculose anterior; pacientes com câncer, linfomas e leucemias; idade e sexo: entre 20 - 40 anos, na proporção de 2 homens para 1 mulher; doenças renais crônicas;a extensão da exposição às gotículas infectadas;

- Suscetibilidade da pessoa à infecção; quantidade de bacilos eliminados pelo indivíduo doente; falta de iluminação, sol e calor, ventilação.

\section{e) Tratamento da tuberculose}

O conhecimento que o M. tuberculosis causa a doença tuberculose já existe há mais de cem anos, sendo que nos últimos 50 existe tratamento efetivo. Contudo, o problema da tuberculose no mundo é tão grande quanto antes, e uma das causas apontadas pela Organização Mundial de Saúde (WHO 2004) é a questão organizacional, de como aplicar o tratamento medicamentoso completo, como implementar de fato o Programa de Controle da Tuberculose.

O tratamento da tuberculose é longo, podendo durar de seis a nove meses ${ }^{10}$, e requer grande empenho do paciente, do serviço e da rede de profissionais de saúde para garantir a melhor adesão possível. Segundo as diretrizes preconizadas pelo MINISTÉRIO DA SAÚDE (2002b), o tratamento da tuberculose consiste em:

A) Fase inicial (dois meses): os bacilos são eliminados rapidamente, e pacientes têm

\footnotetext{
${ }^{10} \mathrm{O}$ tratamento de recidiva de tuberculose recomendado tem duração de oito meses, sendo os três primeiros com tratamento supervisionado.
} 
melhora significativa e redução dos sintomas. A grande maioria dos pacientes com exame de escarro positivo têm seus exames negativados em dois meses. Recomenda-se o tratamento supervisionado durante essa fase inicial para garantir que o paciente tome cada dose, o que protege contra o desenvolvimento de resistência (em especial a Rifampicina). O risco de resistência é maior durante os estágios iniciais do tratamento anti-tuberculose.

B) Fase II (quatro a seis meses): é necessário um menor número de drogas, porque houve eliminação de bacilos na fase inicial, mas essas drogas precisam ser administradas durante mais tempo, para eliminar todos os bacilos. A WHO (2004) recomenda o tratamento supervisionado nesta fase para os pacientes que fazem uso da rifampicina, ou ainda uma supervisão semanal. Quando o esquema terapêutico não inclui rifampicina, a recomendação é para tratamento auto-administrado.

Além da tomada de medicamentos, é preciso intensificar as medidas profiláticas e preventivas, o vínculo com o serviço de saúde, o entendimento da doença, do tratamento e dos efeitos colaterais possíveis.

Com a declaração da Organização Mundial de Saúde, em 1993 (apud MINISTÉRIO DA SAÚDE 2002b), de que a tuberculose encontra-se em estado de emergência no mundo, foi recomendada a estratégia DOTS (direct observed treatment short-course), já adotada pelo Brasil há muitos anos, que contempla:

- adesão política por parte das autoridades governamentais;

- estabelecimento de uma rede laboratorial de baciloscopia;

- garantia de medicação;

- $\quad$ sistema de informação adequado e oferta de tratamento supervisionado.

Vários incentivos, como fornecimento de vale-transporte e cestas básicas, foram implementados ao longo da história do atendimento a pacientes com tuberculose no Brasil. Porém, existem relatos de profissionais de saúde afirmando que esses incentivos, em especial a cesta básica, poderiam funcionar como incentivo ao paciente não se curar, para seguir com o benefício.

\section{f) Tratamento de tuberculose em pacientes com HIV}

A co-infecção HIV/tuberculose altera de forma expressiva o comportamento clínico e a história natural de ambas as doenças. A infecção pelo HIV aumenta a suscetibilidade à infecção por M. tuberculosis, e aumenta o risco de progressão da infecção para doença 
(caso de tuberculose).

As recomendações do MINISTÉRIO DA SAÚDE (2005b) para TARV entre adultos infectados pelo HIV co-infectados com tuberculose estão detalhadas no Anexo 2. Inicia-se o tratamento da tuberculose, em períodos de seis a nove meses, com avaliação das condições clínico-laboratoriais para introdução da TARV.

A adesão adequada aos esquemas antituberculose e ARV concomitantes é um grande desafio: dependendo do esquema adotado, o indivíduo tem que ingerir cerca de 700 a 900 comprimidos/mês. Os efeitos colaterais também podem ser intensos, em especial nas primeiras semanas. Por isso, considera-se o adiamento do ARV para pacientes com coinfecção HIV-tuberculose que apresentam quadros de imunodeficiência avançados.

\subsection{CO-INFECÇ̃̃O HIV/TUBERCULOSE}

As diretrizes preconizadas pelo Ministério da Saúde em relação ao tratamento da coinfecção aids/tuberculose são as seguintes:

É importante considerar que a adesão adequada a ambos esquemas, antituberculose e antiretroviral, tomados de forma concomitante, é um grande desafio para o paciente, devido à elevada quantidade de comprimidos/ cápsulas a serem ingeridas ao dia e à ocorrência de efeitos colaterais, particularmente nas primeiras semanas de tratamento. Portanto, deve-se considerar, sempre que possível, o adiamento do início do tratamento antiretroviral em pacientes com co-infecção HIV/tuberculose, particularmente naqueles que apresentam quadros de imunodeficiência menos graves do ponto de vista clínico-laboratorial. A indicação de início da TARV em pacientes com co-infecção HIV/tuberculose deve seguir os mesmos parâmetros clínicos e imunovirológicos estabelecidos para pacientes HIV+ sem tuberculose em atividade, recentemente atualizados no Consenso. (MINISTÉRIO DA SAÚDE 2005b).

No final do ano 2000, cerca de 11,5 milhões de pessoas infectadas pelo HIV no mundo estavam co-infectadas pelo M. tuberculosis, segundo a WHO (2004), sendo 4\% na América Latina e Caribe, como demonstrado na tabela abaixo: 
Tabela 2. Número de adultos acima de 15 anos de idade co-infectados aids/tuberculose no final do ano 2000.

\begin{tabular}{lcr}
\hline Região & $\begin{array}{l}\text { Número de pessoas co- } \\
\text { infectadas }\end{array}$ \\
\hline África & 7.979 & 70 \\
Américas & 468 & 4 \\
Europa e Mediterrâneo & 196 & 2 \\
Sudeste Asiático & 2.269 & 20 \\
Pacífico & 427 & 4 \\
Total & 11.440 & 100 \\
\hline
\end{tabular}

Fonte: WHO, 2004.

Segundo a Organização Mundial de Saúde (WHO,2004), a presença do HIV aumenta o risco e a taxa de progressão de infecção latente ou recente por $M$. tuberculosis para desenvolvimento da doença. A tabela abaixo mostra o efeito da infecção pelo HIV no risco de desenvolvimento de tuberculose por pessoas infectadas pelo M. tuberculosis.

Quadro 3. Risco de desenvolvimento de tuberculose em pacientes infectados pelo M. tuberculosis em função do status sorológico para HIV.

\begin{tabular}{ll}
\hline Status sorológico de HIV & $\begin{array}{l}\text { Risco de desenvolvimento de } \\
\text { tuberculose }\end{array}$ \\
\hline HIV negativo & $5-10 \%$ \\
HIV positivo & $50 \%$ \\
\hline Fonte: WHO, 2004
\end{tabular}

Fonte: WHO, 2004.

Os princípios do controle da tuberculose são os mesmos para pacientes com ou sem HIV. Na co-infecção aids/tuberculose ocorrem (WHO 2004) a supervisão inadequada do tratamento medicamentoso da tuberculose, baixas taxas de cura, altas taxas de recaídas de tuberculose, alta razão de abandono por causa dos efeitos adversos e aumento da transmissão de linhagens resistentes entre populações confinadas que têm infecção pelo HIV.

\subsubsection{Tipos de tuberculose em pacientes HIV+}

Com a progressão da infecção pelo HIV, as células T CD4+ diminuem em número e função. Essas células têm papel fundamental na defesa do organismo contra os bacilos da tuberculose, e o sistema imunológico fica menos capaz de prevenir o crescimento e dispersão do M. tuberculosis. A disseminação rápida e o surgimento de formas clínicas de tuberculose extrapulmonar são comuns. 
a) Tuberculose pulmonar: é a forma mais comum de tuberculose entre pacientes com aids. A forma depende do grau de imunossupressão.

b) Tuberculose extrapulmonar: as formas mais freqüentes de tuberculose extrapulmonar são a linfadenopatia, derrame pleural, doença no pericárdio, tuberculose miliar, meningite, tuberculose disseminada.

No indivíduo infectado pelo HIV, a presença de outras infecções, incluindo tuberculose, pode aumentar a multiplicação do HIV em quantidade e velocidade, o que pode resultar numa progressão mais rápida da aids (WHO 2004).

\subsection{USO DE DROGAS}

A história da humanidade nos mostra que o uso de drogas é apenas um modo de vida. As pessoas sempre as utilizaram e continuarão utilizando drogas nos mais diferentes contextos. Segundo SEIBEL (2002), uma pequena parcela dos usuários pode estabelecer com a droga um comportamento patológico.

A palavra droga tem etimologia controversa. Segundo TOSCANO (2002), pode ter vindo do persa droa, que significa odor aromático; pode ter vindo do hebraico rakab, perfume, ou do holandês droog, substância ou folha seca.

A questão do uso de drogas perpassa a própria história da humanidade. A relação do homem com as substâncias psicoativas envolve medicina, ciência, magia, religião, cultura, festas e deleite (TOSCANO 2002). Para ESCOHOTADO (2000), a história geral da humanidade tem relação direta com o uso de drogas, na evolução da medicina, da moral, da religião e da economia, bem como os mecanismos de controle político.

A definição da legalidade ou não de uma droga está diretamente ligada a esses mecanismos - por exemplo, durante muitos séculos a cafeína era considerada droga ilícita no Oriente Médio, com punições severas para usuários.

Substâncias psicoativas e drogas psicoativas são aqui utilizados como sinônimos, e referem-se àquelas substâncias que modificam o estado de consciência do usuário. Apesar da palavra 'droga' estar diretamente relacionada a doenças, problemas e outros estereótipos, é importante lembrar que são utilizadas por toda classe de pessoas, não apenas 
por adictos ou dependentes (SEIBEL 2002).

O uso de substâncias psicoativas pode estar relacionado a rituais religiosos, relação peculiar entre homem e droga, restrito a contextos e rituais específicos, apresentando-se como um fenômeno que deve ser diferenciado da patologia drogadictiva (BETARELLO 1998).

Em relação ao álcool, segundo TOSCANO (2001), a palavra deriva do árabe alkuhl, significando essência. Seu processo de destilação foi descoberto na Arábia no ano 800. Quase todas as civilizações das quais temos registros conheceram o álcool; o consumo ocorre em várias circunstâncias, com diferentes motivações. No mundo antigo, para livrarse das enfermidades, do castigo e das impurezas, o homem costumava curvar-se às divindades e submeter-se a sacrifícios de todo tipo. Vítimas animais ou mesmo humanas eram oferecidas a algum deus ou deusa com o intuito de conseguir seu favor.

Segundo ESCOHOTADO (2000), tal desejo de purificação ritual, ou catártico, é universal, porém na Grécia Antiga o pharmakós, ou bode expiatório, foi substituído pelo phármakon, que significa remédio ou veneno. Como para a escola hipocrática, enfermidade e cura eram consideradas resultados de processos naturais, em vez de utilizar algum pharmakós para absorver a impureza alheia, a nova medicina passa a receitar o pharmakón. É a partir deste marco que as drogas deixaram de fazer parte do sobrenatural.

No Corpus Hipocraticum consta que as substâncias atuam "esfriando, aquecendo, secando, umedecendo, contraindo, relaxando ou fazendo dormir". Podia-se curar inclusive atacando o próprio organismo, utilizando-se do fogo, para desinfetar uma ferida. O essencial passava a ser então a proporção entre dose ativa e dose letal, com uma substância podendo ser ao mesmo tempo remédio e veneno, dependendo da dose, o que eu $\mathrm{m}$ dos fundamentos da farmacologia científica (ESCOHOTADO 2000).

No mundo greco-romano, a necessidade de moderação no uso de drogas foi valorizada. A palavra droga expressa tanto o que serve para matar, quanto o que serve para curar.

Com o Cristianismo, porém, foram evidenciadas as maiores restrições quanto ao uso de psicoativos. A instituição católica foi proibicionista em relação às drogas e responsável por importantes mudanças de concepção e pela censura em relação à farmacopéia grecoromana. A moral cristã levou a uma grande proscrição de drogas psicoativas, sendo o 
código cristão estrito na condenação das plantas ditas 'diabólicas', bem como a relação entre a expulsão do paraíso e a proibição de certas plantas. Importante refletir que, apesar disso, o vinho constitui-se em elemento de grande importância, simbolizando o sangue de Cristo.

A Idade Média acumulou todo um saber herbário, alquímico e secreto, além de uma prática popular sobre as plantas. A Igreja Católica combateu fortemente a relação entre uso de drogas e exercício da sexualidade, com a publicação em 1486 de um código de 'caça às bruxas' escrito por Jacob Sprenger e Heinrich Kraemer, sob o título Malleus Maleficarum, bastante difundido na Europa e publicado até 1669, a serviço da Inquisição (BEAUCHESNE 1989).

A associação entre o uso de drogas e infecção pelo HIV marcou o final do século XX. O incremento do uso de drogas pela via injetável, com seu conseqüente risco de disseminar pelo sangue agentes infecciosos potencialmente letais, como o HIV e os vírus das hepatites $\mathrm{B}$ e $\mathrm{C}$, provocou uma verdadeira revolução nas políticas de saúde pública (ANDRADE 2003).

Na Holanda, na década de 80, a prevalência de hepatites entre usuários de drogas injetáveis era tão elevada que os gestores da saúde implementaram a estratégia de Redução de Danos (harm reduction). A Redução de Danos é definida como uma política social que tem como objetivo prioritário minimizar os efeitos negativos decorrentes do uso de drogas. É considerada polêmica, uma vez que admite a inevitabilidade de um dado nível de consumo de drogas na sociedade, e define-se como objetivo prioritário a redução das conseqüências adversas desse consumo, contrapondo-se ao paradigma americano de exigência de abstinência completa, total e imediata como única forma de relação entre homem e droga.

Nos Estados Unidos, a estratégia de exigência de abstinência fundamenta os grupos de auto-ajuda, como Alcoólatras Anônimos, Narcóticos Anônimos, dentre outros. Nestes grupos, prevalece a concepção de dependência como doença, e como tal deve ser tratada.

Em 1750, surgiu a idéia de que os bebedores eram indivíduos que haviam perdido a capacidade de beber moderadamente. O álcool é visto como o agente causal, enquanto a perda do controle sobre o comportamento de beber é considerada um sintoma característico, e a única via de cura é a abstinência total para todo o resto da vida do sujeito. 
Porém, não há medicamentos - há uma luta diária entre homem e droga, com o lema 'só por hoje', em que cada pessoa se compromete a não ingerir jamais qualquer dosagem de qualquer droga. A droga é vista como capaz de influenciar o sujeito, obrigando-o a comportamentos que jamais teria sem sua influência. Nessa perspectiva, a droga deixa de ser uma substância inerte e passa a ter poderes quase sobrenaturais.

No Brasil, a influência americana norteou as primeiras políticas públicas na área de drogas e aos poucos - e de modo bastante tímido - o paradigma da Redução de Danos vem sendo incorporado. Neste paradigma, assume-se a idéia que haverá consumo de droga, em algum grau. O sujeito que não quer, não pode ou não consegue abandonar o uso de drogas é visto como alguém com direitos e com recursos psíquicos para lidar com a própria saúde e não como alguém que perdeu o controle. É criado o Agente Redutor de Danos, um usuário ou ex-usuário que conhece a rotina dos locais de uso, conhece o linguajar dos usuários, e estabelece na comunidade uma rede de assistência à saúde, vinculando o usuário ao serviço de saúde.

No Brasil, no final da década de 80, a cidade de Santos foi pioneira no estabelecimento da Política de Redução de Danos, disponibilizando insumos aos usuários de drogas injetáveis, com prioridade ao trabalho educativo de redução do HIV/Aids e das hepatites (SEIBEL 2002). A disponibilização de seringas e agulhas gerou polêmica nacional, e o Estado de São Paulo foi o primeiro a ter uma legislação que permite aos profissionais de saúde a disponibilização de insumos de prevenção em 1998. Em todo o país, a prevalência de HIV entre usuários de drogas injetáveis caiu de 40\% no início da epidemia para menos de $13 \%$ em 2003. O Brasil tornou-se referência internacional nas políticas de redução de danos, as parcerias com ONG e avanços na legislação e Direitos Humanos.

No município de São Paulo, apenas em 2001 a estratégia de redução de danos foi implementada nos (então) 19 serviços de DST e Aids, mobilizando todos os profissionais de saúde, capacitando e selecionando agentes redutores de danos, mas sempre contando com a rejeição da maioria dos profissionais de saúde envolvidos (LIMA 2002b; LIMA 2003a).

O conceito de Redução de Danos ampliou-se e não fica restrito ao universo dos usuários de drogas injetáveis. Considera-se a realidade do paciente, e não aquilo que 
idealmente se considera 'perfeito'. A redução de danos vê o paciente como sujeito de suas ações, com direito a escolhas e a ter sua opinião respeitada. Não significa que o profissional de saúde vá abrir mão de seu conhecimento técnico-científico apenas porque o 'paciente não quer'. Não se trata de acatar passivamente um capricho do usuário, mas sim considerar que cientificamente é mais viável que ele modifique pequenos hábitos de vida aos poucos do que uma mudança súbita e radical.

Assim como existem pacientes em que a única redução de danos possível é a abstinência total e definitiva, existem pacientes em que essa possibilidade não se concretiza, e ele necessita de orientações, informações, idéias e estratégias para reduzir seus danos e prejuízos. É um paciente que exige mais do profissional de saúde: mais tempo, mais preparo técnico e atualização científica, maior interação com a história pessoal e familiar, enfim, os pacientes usuários de drogas podem ser beneficiados se os profissionais de saúde tiverem maior abertura para diálogo e para conhecimento da realidade cotidiana.

A chamada "estratégia do terror", com ameaças, amedrontamento, fornecimento de informações falsas de risco de overdose e/ou perda de eficácia dos medicamentos, e exigência imediata de abstinência como única estratégia ainda é empregada nos serviços de atendimento aos usuários e drogas. O paciente, não se sentindo à vontade para relatar a verdade dos fatos, mascara, opta pelo que considera que o profissional de saúde gostaria de ouvir. Nesse cenário surgem as omissões, falhas na ingestão de medicamentos, falta de adesão ao serviço, falta de orientação adequada - por desconhecimento da realidade e ocorr aumento do abandono e redução da adesão.

A implementação do paradigma da Redução de Danos pode levar o sujeito a desejar a abstinência, ou não. Não é prioritário para os profissionais que trabalham na redução de danos a conquista imediata da abstinência. Sabe-se que a frustração do sujeito pela nãoobtenção desta abstinência imediata e definitiva pode piorar sua condição patológica, agravar quadros depressivos e favorecer recaídas (SEIBEL 2002). Na Redução de Danos, os profissionais de saúde, em lugar de exigirem abstinência imediata (que é considerado um procedimento carregado de moral), procuram auxiliar para que o paciente veja a melhor forma de reduzir os danos e evitar a infecção pelo HIV e vírus da hepatite. A abstinência pode ser um objetivo alcançado, mas não é o foco da estratégia (LIMA, 2003b) 
O trabalho do agente redutor de danos tem como objetivo permitir que o próprio sujeito entenda seus recursos emocionais, materiais e sociais para construir uma melhora em sua vida como um todo. As pequenas e duradouras conquistas incentivam o paciente a manter novos comportamentos preventivos e evitar comportamentos de risco. Essa estratégia ainda não foi incorporada a toda rede de atenção básica do serviço de saúde do Brasil, embora na área de aids tenha sido decisiva para redução de UDI infectados de 40\% a menos de 13\% (MINISTÉRIO DA SAÚDE, 2001).

A realidade do atendimento em Saúde Mental segue a medicalização com exigência de abstinência como prática consagrada, sem diálogo e com visão estereotipada do paciente como tendo 'estilo de vida caótico', 'falta de vontade de viver'.

Para que profissional de saúde e o paciente estabeleçam uma relação de confiança e construam um Plano Individual de Adesão, é fundamental trazer ao cenário da consulta médica a possibilidade do paciente apresentar sua condição de dependente, revelar seus hábitos sem ser julgado e desqualificado moralmente. Isso requer que o profissional tenha uma escuta qualificada em relação ao paciente e junto à equipe multiprofissional do serviço de saúde.

É preciso considerar que os pacientes podem ficar frustrados e apresentar resistência ao cumprimento de quaisquer diretrizes quando pelo menos algumas de suas preferências nas decisões relativas ao tratamento não são sequer consideradas. Por exemplo, pacientes que têm pouco poder de decisão em relação ao tratamento têm mais atitudes negativas em relação à terapia anti-retroviral e apresentam baixos níveis de adesão (WEBB et al 2001). A adesão melhora quando as necessidades, preocupações e crenças pessoais dos pacientes são consideradas, e quando possível, uma avaliação sobre custos e benefícios do tratamento (HORNE e WEINMAN 1999).

A estratégia de Redução de Danos tem como fundamento a valorização da cidadania dos usuários: conhecimento de seus direitos e responsabilidades, participação ativa na estruturação de seus caminhos para recuperação e bem-estar. Sua filosofia vem se aplicando a diversas áreas da Saúde Pública, onde são necessárias intervenções atualizadas, modernas e adequadas à realidade dos serviços e pacientes - e não apenas as idealizadas.

Assim como ainda existem pacientes com aids que se denominam "aidéticos", profissionais de saúde que utilizam os rótulos "drogados", "tuberculosos", dentre outros 
rótulos com significados depreciativos ou desmoralizantes, ainda existem dificuldades na compreensão de novas abordagens para atendimento destes pacientes.

Isto requer, dentre outras coisas, uma compreensão mais aprofundada do que seria um sistema de saúde de fato público e acessível para toda a população. Os rótulos simplificam, reduzem o sujeito, aumentam os estigmas e os preconceitos. Se o acesso à Saúde é um direito de todo cidadão brasileiro, garantido na Constituição Federal (BRASIL, 1988), todo cidadão merece o melhor atendimento, independentemente de sua doença ser ou não estigmatizada, de seu comportamento ser julgado como moralmente repreensível, e do quanto sua perspectiva de vida é restrita por sua condição social. 


\section{OBJETIVOS}

\subsection{Objetivo geral}

Subsidiar estratégias em Saúde Pública para o estudo da adesão ao tratamento de HIV e aids por pacientes com aids, tuberculose e usuários de drogas em quatro serviços de saúde de São Paulo no ano de 2005.

\subsection{Objetivos específicos:}

A. Fazer um diagnóstico da situação atual adesão ao tratamento do HIV/Aids, por pacientes com aids, tuberculose e usuários de drogas nos serviços pesquisados;

B. Avaliar o atendimento à tuberculose nos serviços de DST/Aids, no que diz respeito à busca de contactantes, notificação, busca de paciente-fonte e orientação para medidas profiláticas;

C. Verificar os fatores que podem facilitar e melhorar a adesão do paciente aos tratamentos de aids e tuberculose;

D. Verificar os equívocos na ingestão cotidiana dos medicamentos por parte dos pacientes e as estratégias dos profissionais de saúde para monitoramento e avaliação;

E. Avaliar o acompanhamento dos pacientes já vinculados ao serviço de DST e Aids no que se refere ao comportamento sexual e saúde reprodutiva, orientação sobre o uso de psicoativos e interações medicamentosas;

F. Avaliar a relação entre o discurso do profissional de saúde e a sua prática efetiva cotidiana para trabalhar com esse tipo de paciente, as suas necessidades de atualização técnico-científica, as suas limitações e os vínculos institucionais necessários;

G. Apresentar as principais dificuldades dos profissionais de saúde no atendimento aos pacientes com aids, tuberculose e usuários de drogas no que concerne à dependência de psicoativos;

H. Ampliar a visão de assistência, introduzindo a estratégia de Redução de Danos como uma das ferramentas para melhoria da adesão aos tratamentos de aids e tuberculose pelos pacientes usuários de drogas. 


\section{METODOLOGIA}

Esta pesquisa foi realizada no ano de 2005, em quatro serviços públicos de saúde especializados no atendimento a pacientes com Doenças Sexualmente Transmissíveis e Aids, localizados nas quatro diferentes regiões da cidade de São Paulo, com alta prevalência de co-infecção aids/tuberculose e usuários de drogas.

Participaram três serviços da Prefeitura e um do Estado que fazem atendimento referenciado e também atendem demanda espontânea. Em cada serviço selecionado, foram escolhidos para participar os profissionais que são considerados pela direção do serviço como referência para atendimento a pacientes com aids, tuberculose e usuários de drogas. Os pacientes escolhidos tinham esse perfil e eram maiores de idade.

Neste capítulo, serão apresentados:

- a metodologia utilizada (RARE - Rapid Assessment, Response and Evaluation);

- os passos da metodologia de coleta e análise dos dados e

- uma breve caracterização dos serviços e populações selecionados para o estudo.

A escolha deste tema foi feita pelo observado e referido pela literatura como importante para compreender melhor certos aspectos de pacientes com três patologias graves que, embora tenham atualmente tratamentos com cura, no caso da tuberculose, e controle, no caso da aids e da dependência a drogas, há dificuldade em se conseguir uma boa adesão a esses tratamentos, e apresentam alto índice de abandonos.

Também há queixas por parte dos profissionais de saúde quanto às dificuldades para realizar o tratamento destes pacientes; a literatura científica disponível acerca da relação entre pacientes com este perfil e os profissionais de saúde é bastante restrita.

Considerando-se as previstas dificuldades de acesso a esses pacientes, a complexidade do serviço público em saúde no Brasil, e a possibilidade da pesquisa qualitativa em saúde contornar esses problemas, esta metodologia foi a escolhida. A pesquisa qualitativa pode auxiliar numa compreensão mais aprofundada do tema adesão, em especial em relação ao paciente com o que se pode denominar "tríplice estigma": usuário de drogas, com aids e tuberculose. 
Segundo a Organização Mundial de Saúde, em relação à produção científica sobre adesão e tratamento de tuberculose,

há uma lacuna em relação a pesquisas experimentais sobre os efeitos das intervenções para melhorar a adesão ao tratamento da tuberculose. Na pesquisa qualitativa, há questões sobre eficácia e efetividade, podendo complementar pesquisas quantitativas com entrevistas em profundidade abordando porque uma intervenção pode ser efetiva num determinado contexto (WHO 2003).

A metodologia aqui empregada é a metodologia qualitativa denominada RARE Rapid Assessment, Response and Evaluation (NEEDLE 2002), desenvolvida pela equipe do Centers for Disease Control and Prevention (CDC) com base na metodologia RAR (Rapid Assessment and Response) de STIMSON (2000).

A principal diferença entre o RAR de Stimson e o RARE de Needle consiste no acréscimo da avaliação (Evaluation), que é a transformação dos achados da pesquisa em recomendações para formulação de políticas públicas. Essa metodologia foi implementada em 25 países do mundo pelo Global Aids Program (CDC/GAP) desde o ano de 2002, para nortear pesquisas de prevenção à aids nas populações consideradas vulneráveis (são incluídos os usuários de drogas).

É uma metodologia considerada rápida (Rapid), porque compreende um processo limitado para coleta e análise de dados não superior a oito meses; acesso rápido (Assessment) refere-se à característica de permitir acesso a populações até então inacessíveis para realização de pesquisas ou com limites explícitos de participação em estudos científicos; resposta (Response) refere-se a uma característica importante desta metodologia, que é validar os dados cientificamente para subsidiar formulação e reformulação de políticas públicas, submetidas a uma posterior avaliação por parte do coordenador da pesquisa em conjunto com um representante da população-alvo e do gestor, o que constitui a avaliação (Evaluation).

Esta metodologia compreende técnicas combinadas para coleta e análise de dados. Considera-se análise e coleta como processos concomitantes, uma vez que os dados encontrados fundamentam decisões metodológicas de seleção de participantes e ocorrem mudanças nos instrumentos de pesquisa ao longo do processo. Segundo TROTTER (2003), a análise começa com o primeiro dado coletado. 
As técnicas utilizadas na metodologia RARE são as seguintes:

1. Observação: os pesquisadores permanecem nos campos de pesquisa (locais de coleta de dados) durante várias horas, em diferentes períodos, para compreender a dinâmica interna, as relações externas e o fluxo cotidiano. As observações servem para:

a) Conhecer a dinâmica institucional, para planejamento das etapas da coleta de dados e possíveis intervenções futuras.

b) Avaliar o discurso formal dos entrevistados à luz do que se observa na prática cotidiana.

c) Registrar as conversas informais que trazem informações significativas para a condução da pesquisa.

2. Mapeamento: compreende o registro gráfico da estrutura física do campo de pesquisa e seu modus operandi. Quais são os horários divulgados para prestação de serviços, quais são os horários efetivamente cumpridos, como ocorre a divulgação dos serviços internos, como a instituição avalia o próprio trabalho, dentre outros registros que permitam o entendimento da forma como a instituição funciona de fato. Complementa a observação e permite a compreensão da dinâmica institucional e de um "dia típico" daquele local, importantes ferramentas na validação dos dados obtidos nas entrevistas. O mapeamento e a observação permitem a compreensão da dinâmica institucional e a elaboração de estratégias eficazes, pertinentes e adequadas à rotina dos profissionais ou populações que participarão das intervenções.

3. Entrevistas em profundidade: realizadas com a população-alvo e com os chamados informantes-chave ou "experts", que são as pessoas que participam da dinâmica cotidiana do serviço, que têm relação direta com as intervenções já realizadas e com a comunidade. São entrevistados todos os sujeitos que preenchem as condições para compor o universo da população-alvo em suas diferentes representações, além dos sujeitos que participam de seu cotidiano. 


\subsection{Metodologia da coleta de dados:}

A coleta de dados foi realizada em cada um dos quatro serviços mencionados, no período de maio a agosto de 2005, após passar pela análise e aprovação de três comitês de ética, que foram:

1. Faculdade de Saúde Pública da USP (aprovado em dezembro/2004),

2. Secretaria Estadual de Saúde de São Paulo (apresentado em junho de 2004 e aprovado em maio de 2005),

3. Secretaria Municipal de Saúde de São Paulo (apresentado em novembro de 2004 e aprovado em dezembro de 2004).

Todos os entrevistados assinaram duas vias do Termo de Consentimento Livre e Esclarecido (TCLE - Anexos 3a e 3b), com explicações sobre a pesquisa, explicitação da autorização para o entrevistador gravar a entrevista (com garantia de anonimato) e permitia formalmente ao entrevistado interromper a entrevista a qualquer momento, sem qualquer justificativa ou prejuízo pessoal. Uma cópia do TCLE ficou com cada entrevistado, e outra se encontra sob guarda da pesquisadora, juntamente com as fitas gravadas. Todas as entrevistas foram gravadas e integralmente transcritas.

\subsubsection{Etapas da coleta de dados:}

A) Seleção e capacitação das entrevistadoras: foram escolhidas duas profissionais graduadas para participação na realização das entrevistas, em função de sua habilidade como entrevistadoras, experiência prévia em metodologia qualitativa e disponibilidade de tempo. Foram capacitadas especificamente na metodologia RARE com aulas teóricas e treinamentos (simulações) para realizarem, no primeiro mês, as observações e os mapeamentos (Anexo 4) com o registro dos dados em fitas cassete e registros escritos.

Após esta capacitação inicial, as entrevistadoras foram treinadas para realização das entrevistas e transcrição das fitas. As entrevistadoras foram apresentadas aos diretores dos serviços, que por sua vez auxiliaram na indicação dos entrevistados e na viabilização das entrevistas. 
B) Definição de uma fase de pré-testes, para treinamento da linguagem, avaliação do tempo da entrevista (previsto e efetivamente realizado), com supervisões a cada entrevista.

C) Realização de entrevistas: as entrevistadoras discutiam com a pesquisadora, após cinco ou seis entrevistas realizadas, a respeito das impressões mais significativas, impactos diante dos entrevistados, dificuldades encontradas (práticas e teóricas), soluções encontradas, necessidade de providências diversas, ou mesmo novos problemas. Cada transcrição era lida e discutida com a pesquisadora.

Essa supervisão era necessária, uma vez que o impacto dos temas abordados muitas vezes era intenso. As entrevistadoras foram orientadas a manter um "diário de campo", com registro minucioso das atividades, pessoas contactadas, tarefas planejadas e tarefas cumpridas, sentimentos e sensações que tanto o entrevistado quanto o entrevistador apresentaram.

\subsubsection{Seleção dos serviços e da população pesquisados:}

Os critérios para escolha dos serviços e da população pesquisados (perfil e quantidade) foram a identificação de informantes-chave ("experts") (LIMA 2002; NEEDLE 2002).

a) Informantes-chave: são considerados aqueles sujeitos e/ou campos em que há especificidade e singularidade da amostragem, considerada representativa do conjunto de sujeitos e/ou campos necessário para compreensão do fenômeno.

b) Saturação: respostas iguais ou muito semelhantes a questões idênticas, aplicadas a diferentes entrevistados em seqüência. As respostas iguais, sem qualquer inovação de conteúdo ou forma, em número pré-estabelecido de entrevistas, refletem o esgotamento daquele tema, não necessitando de maior número de entrevistados.

Os quatro serviços públicos de DST/Aids em São Paulo, como já foi mencionado, foram escolhidos pelos seguintes critérios: um em cada região da cidade, com alta prevalência de co-infecção aids/tuberculose e alta freqüência de usuários de drogas.

Em cada serviço, a direção indicou os profissionais de saúde que atendiam à população de co-infectados aids/tuberculose que também eram usuários de drogas. Estes profissionais de saúde, por sua vez, indicaram os pacientes que se adequavam ao perfil. 


\subsubsection{Processo de coleta de dados nos serviços selecionados:}

A) Entrevista inicial com direção dos serviços: apresentação do projeto de pesquisa, do parecer do respectivo comitê de ética e das entrevistadoras para os diretores dos serviços, solicitação de auxílio para permanência na instituição para observação, mapeamento e escolha dos entrevistados.

B) Apresentação às entrevistadoras, pelo diretor do serviço, de um profissional aqui denominado recrutador (na Prefeitura é chamado de Interlocutor de Pesquisa), que por sua vez ajudou na apresentação destas entrevistadoras aos profissionais de saúde selecionados, bem como na identificação e acesso aos pacientes selecionados.

C) Mapeamentos e observações: foram realizados durante cinco períodos de, no mínimo, quatro horas cada (em diferentes momentos do dia e em diferentes dias da semana). Os dados obtidos foram registrados pelas entrevistadoras no "diário de campo" e discutidos com a pesquisadora principal desde a primeira visita. Foram solicitados, junto à Área Técnica de DST/Aids da Secretaria Municipal de Saúde de São Paulo (setor de Pesquisa e Vigilância Epidemiológica), e junto aos diretores dos serviços, os dados oficiais sobre a estrutura de cada um.

D) Realização das entrevistas: em todos os serviços, os profissionais de saúde que trabalham com os pacientes com aids/tuberculose e usuários de drogas foram os primeiros entrevistados (Anexo 5), e auxiliaram na indicação e eventualmente abordagem dos pacientes que poderiam ser entrevistados.

E) Discussão das entrevistas realizadas à luz do mapeamento e observações - Triangulação: cada entrevista foi gravada e seu conteúdo discutido com a pesquisadora, ao mesmo tempo em que eram realizadas as transcrições da fita cassete para o registro impresso.

F) Triangulação dos dados obtidos nas entrevistas com os dados obtidos nas observações e mapeamentos. Decisões sobre continuidade ou não das entrevistas naquele serviço. 


\subsection{Instrumentos de pesquisa: roteiros}

Os roteiros foram construídos após a revisão bibliográfica, com objetivo de aprofundar os temas considerados, na literatura, como relevantes para discussão da adesão nesse contexto particular de pacientes com aids, tuberculose e usuários de drogas.

Foram utilizados nesta pesquisa três tipos diferentes de roteiros, a saber:

a) Roteiro para as entrevistadoras, para obtenção de dados de mapeamento e das observações (Anexo 4);

b) Roteiro para entrevistas em profundidade com profissionais de saúde, médicos e não-médicos (Anexo 5);

c) Roteiro para entrevistas em profundidade com os pacientes (anexo 6).

Para a realização das entrevistas em profundidade, o tipo de instrumento foi o roteiro semi-estruturado, com algumas perguntas-chave e possibilidade de aprofundamento de algumas das questões abordadas através de perguntas pré-definidas, chamadas de 'perguntas de sondagem'.

Foram realizados pré-testes, com oito pacientes (dois de cada serviço) e três profissionais de saúde, para adequações na linguagem e na seqüência dos conteúdos. Após o pré-teste (ou 'piloto'), foram realizadas modificações na ordem das perguntas principais, e adaptações da linguagem, compondo o roteiro final (Anexo 6).

O roteiro básico para todos os entrevistados constava de duas partes: uma parte com os dados para caracterização do entrevistado e outra com as questões temáticas específicas.

\subsubsection{Roteiro para profissionais de saúde médicos e não-médicos}

Consta de duas partes, a inicial para caracterização dos indivíduos selecionados (ver Anexo 5) e a segunda parte com questões semi-estruturadas, com os mesmos eixos temáticos apresentados no roteiro para pacientes: tuberculose, aids, fatores que facilitam/ dificultam a adesão ao tratamento, questão das drogas (incluindo o questionamento sobre os critérios de identificação dos pacientes usuários de drogas).

Essa padronização teve como objetivo ter subsídios para compreender quais os conhecimentos, consensos e contradições que os pacientes e os profissionais de saúde selecionados têm em relação a esses temas. 
No quadro 4 está apresentada a relação entre os eixos temáticos escolhidos e as questões correspondentes, no roteiro semi-estruturado para profissionais médicos e nãomédicos selecionados em cada um dos quatro serviços.

Quadro 4. Eixos temáticos e questões correspondentes das entrevistas a profissionais de saúde, médicos e nãomédicos, em quatro serviços de São Paulo, 2005.

\begin{tabular}{|c|c|}
\hline TEMA & QUESTÕES CORRESPONDENTES \\
\hline 1. Tuberculose & $\begin{array}{l}\text { 2. Frente ao paciente com aids, como faz para buscar tuberculose? } \\
\text { 8. Comente a respeito dos pacientes com tuberculose neste serviço. } \\
\text { - acompanhamento, } \\
\text { - tipos de tratamento oferecido, } \\
\text { - perfil dos pacientes, } \\
\text { - busca de faltosos e/ou ausentes } \\
\text { - busca de contactantes e paciente-fonte } \\
\text { - registro dos casos no serviço. }\end{array}$ \\
\hline 2. Aids & $\begin{array}{l}\text { 4. Quais os medicamentos mais empregados atualmente no } \\
\text { tratamento da aids? }\end{array}$ \\
\hline 3. Drogas & $\begin{array}{l}\text { 3. Como você identifica um paciente usuário de drogas psicotrópicas } \\
\text { (se o profissional não mencionar álcool, incluir: “e o paciente } \\
\text { usuário de álcool?”)? }\end{array}$ \\
\hline 4. Fatores que facilitam & $\begin{array}{l}\text { 5. O que você tem observado em relação a fatores que ajudam na } \\
\text { eficiência dos tratamentos para aids? E para tuberculose? } \\
\text { 9. Em sua opinião, o que facilita a adesão do paciente à terapia } \\
\text { ARV? }\end{array}$ \\
\hline 5. Fatores que dificultam & $\begin{array}{l}\text { 6. Como seriam os pacientes 'difíceis' ou 'fáceis' em relação ao } \\
\text { tratamento? } \\
\text { 9.a. O que dificulta [a adesão do paciente à terapia ARV]? }\end{array}$ \\
\hline 6. Sugestões & $\begin{array}{l}\text { 12. O que você acha importante para os médicos (profissionais de } \\
\text { saúde) fazerem, para ajudar os pacientes mais 'difíceis' a aderir à } \\
\text { terapia? }\end{array}$ \\
\hline
\end{tabular}

Com o objetivo de avaliar a rotina no serviço, o grau de conhecimento e atualização técnico-científica dos profissionais de saúde, os recursos de atualização disponíveis e formas de obtenção de informações no cotidiano, foram incluídos tópicos específicos, apresentados no quadro 5: 
Quadro 5. Eixos temáticos e questões correspondentes das entrevistas a profissionais de saúde, médicos e não-médicos, em quatro unidades de saúde de São Paulo, 2005.

\begin{tabular}{|c|c|}
\hline TEMA & QUESTÕES CORRESPONDENTES \\
\hline 1. Rotina no serviço & $\begin{array}{l}\text { 1. Fale um pouco sobre sua rotina de } \\
\text { trabalho aqui no serviço }\end{array}$ \\
\hline $\begin{array}{l}\text { 2. Falência Terapêutica nos tratamentos de } \\
\text { aids e tuberculose }\end{array}$ & \multirow{5}{*}{$\begin{array}{l}\text { 10. Fale um pouco sobre Falência } \\
\text { terapêutica - o que é? E resistência? } \\
\text { Comente um pouco sobre subtipos de HIV, } \\
\text { genotipagem para HIV, tuberculose } \\
\text { multidrogarresistente. }\end{array}$} \\
\hline 3. Genotipagem do vírus HIV & \\
\hline $\begin{array}{l}\text { 4. Resistência aos medicamentos anti- } \\
\text { retrovirais e tuberculostáticos }\end{array}$ & \\
\hline 5. Sub tipos de HIV & \\
\hline $\begin{array}{l}\text { 6. Tuberculose } \\
\text { definição }\end{array}$ & \\
\hline 7. Interações medicamentosas & $\begin{array}{l}\text { 7. Quais os efeitos da interação dos } \\
\text { medicamentos } \\
\text { psicotrópicas? }\end{array}$ \\
\hline $\begin{array}{l}\text { 7.1. Informações sobre interações } \\
\text { medicamentosas }\end{array}$ & $\begin{array}{l}\text { 11. Como você faz quando precisa de uma } \\
\text { informação sobre interação farmacológica? } \\
E \text { os problemas do dia-a-dia, a quem } \\
\text { recorre? }\end{array}$ \\
\hline
\end{tabular}

\subsubsection{Roteiro para entrevistas com os pacientes}

Este roteiro também era composto de duas partes: uma inicial, com questões objetivas para caracterização do perfil de cada entrevistado, e que também serviam como um "aquecimento" na interação entrevistador-entrevistado (ver Anexo 6).

A segunda parte trazia questões semi-estruturadas (com 'sondagens' previstas para tentar abranger tópicos eventualmente não-mencionados pelo entrevistado), tinham como foco os temas mais complexos, relativos a adesão e à tuberculose.

Os roteiros para os pacientes foram estruturados com perguntas relativas aos respectivos eixos temáticos: 
Quadro 6. Eixos temáticos e questões correspondentes das entrevistas a pacientes com AIDS, tuberculose e usuários de drogas em quatro unidades de saúde de São Paulo, 2005.

\begin{tabular}{|c|c|}
\hline TEMA & Questões correspondentes no roteiro \\
\hline 1. Aids: revelação diagnóstica & $\begin{array}{l}\text { 1. Há quanto tempo você tem o diagnóstico de } \\
\text { HIV? } \\
\text { 2. Gostaria que você falasse sobre o seu } \\
\text { diagnóstico de HIV. Quem deu, como foi? } \\
\text { 2.a. Por que você fez o teste? } \\
\text { 2.b.Como foi para você receber a notícia? }\end{array}$ \\
\hline 1.a. Aids: tratamento & $\begin{array}{l}\text { 4. Como foi o período desde o diagnóstico de HIV+ até } \\
\text { o tratamento? } \\
\text { 4.a. Como foi o início do tratamento? } \\
\text { 4.b. Qual o esquema terapêutico que você está } \\
\text { hoje? }\end{array}$ \\
\hline
\end{tabular}

1.b. Aids: abandono

(como sondagem à questão 6 , vamos falar um pouco sobre seu tratamento atual para aids) Você já abandonou o tratamento ARV? Por quê?

O que fez com que você voltasse a se tratar?

1.c. Aids: situação atual - relações afetivas, 5. Como é sua vida afetiva hoje em dia? Tem parceiro saúde sexual e reprodutiva fixo? (caso sim) Fazem algum tipo de prevenção? Qual?

2. Tuberculose: diagnóstico e tratamento inicial 8 . Gostaria que você me falasse de sua tuberculose. Como você soube? Que tratamento você fez, na época?

2.a. Tuberculose: tratamento atual 9. Fale sobre seu tratamento atual de tuberculose. Qual o esquema atual de tratamento.

3. Drogas: uso pré-diagnóstico HIV+, uso atual, 11. Eu gostaria que você falasse um pouco sobre o seu início do uso de drogas, tratamentos realizados, uso de drogas...

estratégias atuais de uso, abstinência, uso de 11.a. álcool-5.b. outras

drogas e terapia ARV

11.c. Com que idade você começou a usar drogas? Que drogas utilizava?

11.d. E hoje em dia, como está seu uso de drogas?

12..Com quem você fala sobre seu uso de drogas, no serviço e fora dele? Que tipo de influência teve ou tem no tratamento?

\begin{tabular}{|c|c|}
\hline 4. Fatores que facilitam a adesão ao tratamento & 7. O que te ajuda a tomar medicação? \\
\hline 5. Fatores que dificultam a adesão ao tratamento & $\begin{array}{l}\text { 10. Dos medicamentos que você toma para aids, o que } \\
\text { te atrapalha? }\end{array}$ \\
\hline $\begin{array}{l}\text { 6. Efeitos colaterais (ou efeitos adversos): quais } \\
\text { os que foram (ou são) sentidos, qual a influência } \\
\text { no tratamento }\end{array}$ & $\begin{array}{l}\text { 14. Fale um pouco sobre os efeitos colaterais dos } \\
\text { medicamentos... } \\
\text { 14.. Como os efeitos colaterais interferem no seu } \\
\text { tratamento? } \\
\text { (como sondagem da questão 14. Que tipo de ocorrência } \\
\text { você já teve em relação a interrupção do tratamento?) }\end{array}$ \\
\hline $\begin{array}{l}\text { 7. Tratamento supervisionado para aids } \mathrm{e} \\
\text { tuberculose }\end{array}$ & $\begin{array}{l}\text { 6. Fale sobre seu tratamento de tuberculose... } \\
\text { 6.a.Fale sobre seu tratamento de HIV... }\end{array}$ \\
\hline 8. Sugestões & $\begin{array}{l}\text { 7. Que sugestões você teria para os profissionais de } \\
\text { saúde (os médicos, os psicólogos, etc) para ajudarem os } \\
\text { pacientes com aids, tuberculose, que usam drogas, para } \\
\text { que esses pacientes façam um bom tratamento? } \\
\text { (ou como sondagem na questão } 2 \text { comente sobre o seu } \\
\text { diagnóstico de HIV). }\end{array}$ \\
\hline
\end{tabular}




\subsubsection{Estrutura do Banco de Dados}

O banco de dados, armazenado em CD rom, contém:

- a íntegra das transcrições de todas as entrevistas realizadas com profissionais de saúde e pacientes, resguardados todos os dados de anonimato;

- as planilhas de dados de caracterização das populações escolhidas, devidamente codificadas;

- a estruturação básica da análise de conteúdo: conjuntos de quodes ou trechos de todos os entrevistados, segundo grandes categorias de análise (descritas em detalhes neste capítulo) e segundo categoria de entrevistado. Por exemplo: trechos de TUBERCULOSE de profissionais de saúde (de todos os 37 entrevistados);

- os termos de consentimento livre e esclarecido originais para pacientes e para profissionais de saúde;

- os roteiros semi-estruturados aplicados aos entrevistadores.

\subsection{Breve caracterização dos serviços, profissionais de saúde e pacientes selecionados:}

Em resumo, os critérios de seleção dos serviços pesquisados foram:

- Terem alta prevalência de co-infecção aids/tb e usuários de drogas;

- Pertencerem um a cada região da cidade de São Paulo.

Em relação aos profissionais de saúde, foram entrevistados todos aqueles que, segundo informação da direção de cada serviço, eram considerados referência naquele serviço para atendimento à população de pacientes com aids, tuberculose e usuários de drogas. O critério para seleção dos pacientes foi: ter aids (com diagnóstico), tuberculose (típica ou multidrogarresistente) e ser usuário de drogas há pelo menos um ano (drogas lícitas ou ilícitas). 


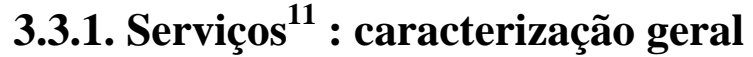

\section{a) Centros de Referência}

Os Centros de Referência/CR em DST/AIDS são unidades de prevenção e assistência que dão suporte aos serviços de controle das DST/AIDS. Realizam exames diagnósticos, tanto os de rotina como os de urgência (incluindo endoscopia, ultrassonografia e radiologia) e desenvolvem projetos e programas de orientação e prevenção de doenças sexualmente transmissíveis.

\section{b) Ambulatórios de Especialidades}

São unidades que prestam atendimento especializado em: cardiologia, neurologia, dermatologia, ortopedia geral, cirurgia geral, ginecologia, otorrinolaringologia, oftalmologia, pneumologia, fonoaudiologia, psiquiatria e serviço social. Alguns Ambulatórios de Especialidades contam ainda com outras especialidades como clínica de queimados, reumatologia, endocrinologia, urologia, infectologia (incluindo DST/AIDS) e especialidades infantis.

\section{c) Serviço de Assistência Especializada/SAE}

São unidades de saúde que realizam atividades de prevenção, diagnóstico e tratamento dos pacientes portadores de várias doenças sexualmente transmissíveis, entre elas o HIV/AIDS. Contam com um pequeno laboratório e uma equipe diversificada de profissionais, incluindo médicos em mais de uma especialidade, psicólogo, nutricionista, assistentes sociais, educadores, entre outros. Todas as unidades funcionam de $2^{\mathrm{a}}$ a $6^{\mathrm{a}}$ feira, das 7 às 19 horas.

\section{Serviços selecionados}

Os serviços escolhidos para esta pesquisa são serviços públicos de Saúde, da área temática de DST/Aids, de cada um dos três tipos existentes na rede de referência (detalhados acima), cada um localizado em uma região do município de São Paulo.

Todos têm alta prevalência de co-infecção aids/tuberculose e grande número de pacientes usuários de drogas. São três serviços municipais (simbolizados por $\mathrm{SM}=$ Serviço Municipal) e um Serviço Estadual (representado por SE = Serviço Estadual).

\footnotetext{
${ }^{11}$ Dados obtidos na internet http://www.prefeitura.sp.gov.br/aids e Área Temática de DST e Aids da Prefeitura de São Paulo, Setor de Pesquisa.
} 
Cada um dos três serviços selecionados, da prefeitura de São Paulo e o serviço estadual, têm uma estrutura e um perfil de atendimento específicos. Para resguardar o anonimato, aqui apenas serão apresentados em linhas gerais alguns pontos fundamentais do tipo de serviço prestado e os dados de identificação codificados.

\section{Peculiaridade do Município de São Paulo: o PAS}

Na prefeitura de São Paulo, muitos dos profissionais que atualmente trabalham em DST e aids foram deslocados de seus locais de origem (em média há dez anos) para atendimento às DST/Aids por uma questão política: na década de 90, os profissionais que não aderiram ao Plano de Assistência à Saúde (PAS), da então administração municipal (1992) foram "castigados" e deslocados para os serviços diferentes de suas especialidades, como por exemplo o de aids. Foi uma maneira estratégica da administração explicitar o descontentamento com os profissionais que apoiavam o Sistema Único de Saúde e repudiavam a estratégia do PAS. Não houve preparação técnica, na época, para atendimento aos pacientes com aids, tampouco privilégio de escolha de trabalho próximo ao local de moradia (prática habitual no serviço do município de São Paulo).

Apenas em 2001, com a mudança na administração municipal, é que São Paulo (município) passou a fazer parte do Sistema Único de Saúde, e portanto participar do Orçamento da União e ter verba para a área de saúde alocada pelo Governo Federal, com repasse feito pelo Estado. Em termos de recursos humanos, os profissionais tiveram a oportunidade de escolher entre continuar no atendimento a pacientes com aids ou voltar às suas antigas funções no serviço de saúde, no momento anterior ao PAS. Nos serviços pesquisados, mais de $90 \%$ dos profissionais optaram por continuar trabalhando nos serviços de aids e não retornar aos antigos postos.

Em relação ao atendimento de tuberculose, todos os serviços recebiam (até outubro de 2004) subsídios da USAID para tratamento de tuberculose, com fornecimento de cestas básicas e vale-transporte.

A seleção de serviços, como foi mencionado, seguiu dois critérios: pelo menos um serviço de cada região do município de São Paulo, com alta prevalência de co-infecção aids/tuberculose e alto índice de usuários de drogas. Ao final, foram selecionados três serviços municipais, sendo um Serviço de Atendimento Especializado (região Leste), um 
Centro de Referência (zona Norte) e um Ambulatório de Especialidades (zona Sul), e o serviço Estadual localizado na região Central da cidade.

Quadro 7. Serviços de Saúde de São Paulo segundo tipo de atendimento prestado e localização. São Paulo, 2005 .

\begin{tabular}{lll}
\hline Serviço/ sigla utilizada & Tipo de atendimento & Localização \\
\hline SM 1 & SAE & Zona Leste \\
SM 2 & Centro de Referência & Zona Norte \\
& Ambulatório de & Zona Sul \\
SM 3 & Especialidades & \\
& Centro de Referência & Região Central \\
\hline
\end{tabular}

\subsubsection{Caracterização dos profissionais de saúde selecionados:}

O critério utilizado foi de entrevistar os "experts" ou informantes-chave, ou seja, os profissionais de saúde que foram indicados pelos diretores dos serviços como referência de atendimento e trabalham diretamente com a população-alvo (pacientes com aids, tuberculose e usuários de drogas).

Tabela 3. Profissionais de saúde médicos e não-médicos entrevistados nos quatro serviços de saúde de São Paulo, segundo tipo de serviço, 2005.

\begin{tabular}{llllll}
\hline SERVIÇO & Médicos & $\%$ & Não-médicos & $\%$ & Total \\
\hline SM 1 & 5 & 55,6 & 4 & 44,4 & 100,0 \\
SM 2 & 8 & 61,5 & 5 & 38,5 & 100,0 \\
SM 3 & 1 & 25,0 & 3 & 75,0 & 100,0 \\
SE 4 & 3 & 27,3 & 8 & 72,7 & 100,0 \\
Total & 17 & 45,9 & 20 & 54,1 & 100,0 \\
\hline
\end{tabular}

A exclusão da escolha de profissionais de saúde foi a dos profissionais que, nos serviços, não atendessem ao público-alvo. Foram entrevistados 37 profisssionais de saúde no total, sendo nove médicos infectologistas e oito médicos não-infectologistas (dois pediatras, três ginecologistas e três clínicos gerais). Todos os profissionais entrevistados tratam, nos respectivos serviços, dos pacientes com aids, tuberculose e usuários de drogas. 
Também foram entrevistados 20 profissionais de saúde não-médicos, sendo quatro psicólogos, uma assistente social, uma terapeuta ocupacional, uma educadora, nove enfermeiros, dois farmacêuticos, um nutricionista e um fonoaudiólogo.

Em relação ao sexo, a amostragem de profissionais de saúde é predominantemente feminina, com quase 82,4\%, dado semelhante ao de BIAGOLINI e RODRIGUES (2001), com profissionais de serviço de referência de tuberculose, em que $82 \%$ eram do sexo feminino.

Cabe a indagar a influência do gênero no atendimento aos pacientes com aids, tuberculose e usuários de drogas: se os pacientes são, em sua maioria, do sexo masculino, solteiros, com faixa etária média de 35 anos, desempregados ou sub-empregados, com escolarização baixa, e os profissionais de saúde, em sua maioria, do sexo feminino, casados, com nível superior de escolarização, quais seriam os possíveis vieses dessa relação no cotidiano do atendimento?

Poderia ser um fator de impedimento para o paciente descrever em detalhes seu comportamento, tanto em relação à sua sexualidade, quanto em relação ao uso de drogas? $\mathrm{Na}$ literatura, é consenso que a relação médico-paciente é fator importante na adesão, porém não há estudos descrevendo a influência do fator gênero nesse sentido.

Quanto à faixa etária, os profissionais de saúde entrevistados têm idade acima de 40 anos, em sua maioria, o que também foi encontrado em estudo no Rio de Janeiro (MALTA et al, 2005), em que a média de idade foi de 42 anos. BIAGOLINI e RODRIGUES (2001) em pesquisa sobre conhecimentos de tuberculose entre profissionais de saúde, trabalharam com população semelhante: a maioria dos entrevistados com faixa etária predominante entre 40 a 49 anos.

Na tabela 4 estão discriminados os dados de caracterização da população de profissionais de saúde que foram selecionados para o presente estudo. 
Tabela 4. Características dos profissionais de saúde entrevistados nos serviços de DST/Aids de São Paulo/ Brasil, que atendem pacientes com aids, tuberculose usuários de drogas. São Paulo, Brasil, 2005.

\begin{tabular}{ccc}
\hline Sexo & $\mathrm{N}$ & $\%$ \\
\hline Masculino & 6 & 16,2 \\
Feminino & 31 & 83,8 \\
Total & 37 & 100,0
\end{tabular}

Faixa Etária

\begin{tabular}{ccc}
\hline $26-35$ & 6 & 16,2 \\
\hline $36-45$ & 15 & 40,5 \\
\hline $46-55$ & 14 & 37,8 \\
\hline $56-65$ & 2 & 5,4 \\
Total & 37 & 100,0
\end{tabular}

Tempo de trabalho em saúde pública (anos)

\begin{tabular}{ccc}
\hline $1-10$ & 6 & 16,2 \\
\hline $11-20$ & 18 & 47,6 \\
\hline $21-30$ & 11 & 29,7 \\
\hline $31-40$ & 2 & 5,4 \\
Total & 37 & 100,0
\end{tabular}

Tempo de trabalho em serviços de DST/Aids (anos)

\begin{tabular}{ccc}
\hline $1-5$ & 4 & 10,8 \\
\hline $6-10$ & 20 & 54,1 \\
\hline $11-15$ & 7 & 18,9 \\
\hline $16-20$ & 6 & 16,2 \\
Total & 37 & 100,0
\end{tabular}

\section{Experiência e capacitação}

em tuberculose

\begin{tabular}{ccc}
\hline Sim & 5 & 13,5 \\
\hline Não & 32 & 86,5 \\
Total & 37 & 100,0
\end{tabular}

\section{Experiência e capacitação}

com dependência química

\begin{tabular}{ccc}
\hline Sim & 3 & 8,1 \\
\hline Não & 34 & 91,9 \\
Total & 37 & 100,0 \\
\hline
\end{tabular}


Em relação ao tempo de atuação como profissional de saúde em saúde pública, os profissionais selecionados têm grande tempo de experiência profissional em serviços públicos de saúde, entre 16 e 30 anos (67,5\%). BIAGOLINI e RODRIGUES (2001) em sua pesquisa sobre conhecimentos de tuberculose entre profissionais de saúde, tiveram em sua amostragem 69\% com mais de dez anos de trabalho na área de saúde. Estar há muitos anos no serviço público de saúde pressupõe conhecimento da rotina dos serviços, das possibilidades e limites de articulações com outros setores da saúde e da rede social local.

A maioria dos profissionais de saúde entrevistados (62,5\%) tem até 10 anos de serviço específico de trabalhos em serviços de aids. Em estudo no Rio de Janeiro, MALTA et al (2005) em estudo com profissionais de saúde e a questão da adesão ao tratamento antiretroviral, tiveram em seus profissionais escolhidos uma média de sete anos de experiência em tratamento de aids (intervalo de 3-10 anos).

Um dado importante sobre os profissionais selecionados refere-se às capacitações prévias e experiência específica no atendimento a tuberculose. Em estudo recente (2001), BIAGOLINI e RODRIGUES entrevistaram 56 profissionais de saúde de uma Unidade Básica de Saúde do Município de São Paulo, que faz parte do Programa de Controle de Tuberculose (PCT). Dos entrevistados, 25,5\% declararam não conhecer nenhuma pessoa com tuberculose, mesmo trabalhando em uma UBS referência para o Programa. Referiram também como sinal mais comum a tosse $(88,0 \%)$, porém não souberam definir um tempo aproximado para considerá-la um sinal específico da doença. Cerca de $10 \%$ não souberam responder o modo de transmissão e metade da amostra (50\%) apresentaram conceito errado sobre o modo de transmissão. Em relação ao tratamento, 10\% não souberam informar. Também 63,6\% associam a tuberculose a algo sombrio, morte, negatividade da doença.

A conclusão é que, apesar do elevado nível de escolaridade apresentado pelos funcionários, o seu conhecimento quanto a tuberculose é fragmentado e desatualizado. Muitos que atuam diretamente com pacientes portadores de tuberculose não têm conceitos mínimos quanto à forma de transmissão e prevenção. Conclui que é necessário que se planeje, execute e avalie uma ação educativa, no sentido de melhorar a qualidade do PCT naquela Unidade Básica de Saúde. 
Considerando-se que os profissionais de saúde entrevistados nos serviços de DST/Aids, exceto no serviço SM 1, não têm treinamento ou atualização em tuberculose, é possível compreender a falta de informações que os pacientes têm em relação à sua doença, o caráter contagioso, as formas de tratamento, as formas de prevenção e profilaxia. Também é possível compreender a falta de sistematização dos registros e a falta de interesse nessas informações.

Como recomendação, sugere-se a capacitação específica dos profissionais que atuam na área de aids para atendimento a tuberculose e pacientes usuários de drogas, seguindo os protocolos específicos do Plano Nacional de Controle da Tuberculose e o protocolo de Saúde Mental da Área Temática do Ministério da Saúde.

Cabe a indagação: como exigir dos profissionais de saúde que atendam aos pacientes com tuberculose seguindo todas as exigências do Programa de Controle de Tuberculose, se eles não recebem a capacitação técnica adequada e necessária?

A verificação de que $81,1 \%$ dos profissionais de saúde entrevistados não têm experiência específica com atendimento a pacientes com tuberculose e 86,5\% não têm experiência específica em atendimento a dependentes químicos traz à tona o questionamento: como é possível esperar um atendimento considerado completo, abrangendo todas as especificidades e complexidades das diferentes patologias, se os profissionais não estão recebendo a preparação técnica necessária?

Resumo do perfil dos profissionais de saúde participantes desta pesquisa: Em resumo, o grupo de profissionais de saúde selecionados para esta pesquisa compreende um predomínio de mulheres acima de 40 anos, com experiência em atendimento em aids de 10 anos ou menos, sem experiência específica com atendimento a pacientes com tuberculose e usuários de drogas (exceto a atividade cotidiana nos serviços) e com mais de 15 anos de atuação em saúde. No trabalho de MALTA et al (2005), o grupo escolhido foi semelhante: profissionais com idade média de 42 anos, cerca de sete anos de experiência em atendimento em aids, porém não foi pesquisado sobre a experiência anterior com tuberculose e dependência química destes profissionais. 


\subsubsection{Caracterização dos pacientes escolhidos para esta pesquisa}

A seleção dos pacientes seguiu os critérios: usuários dos serviços de DST e Aids que tivessem aids, tuberculose e fossem usuários ou ex-usuários de drogas no último ano (2004). Portanto, para inclusão dos 27 pacientes entrevistados foram considerados:

- ser maior de 18 anos,

- ter diagnóstico de aids (há qualquer tempo),

- ter tuberculose (pulmonar ou extrapulmonar): estar em tratamento em 2004,

- ser ou ter sido recentemente (um ano) usuário de drogas (lícitas ou ilícitas).

Os critérios para exclusão foram os seguintes:

- $\quad$ ser menor de idade,

- não ter tido tuberculose,

- $\quad$ não ser ou ter sido usuário de drogas (lícitas ou ilícitas).

Tabela 5. Pacientes entrevistados por serviço de DST/Aids, nos quatro serviços de saúde de São Paulo, 2005.

\begin{tabular}{clc}
\hline Serviço & $\mathrm{N}=$ pacientes & $\%$ \\
\hline SM 1 & 7 & 26,0 \\
SM 2 & 11 & 40,5 \\
SM 3 & 4 & 14,8 \\
SE 4 & 5 & 18,7 \\
Total & 27 & 100,0 \\
\hline
\end{tabular}

O anexo 10 traz em detalhes a codificação dos dados de caracterização dos pacientes em software SPSS.

A previsão inicial era de 11 a 12 pacientes serem entrevistados em cada serviço. Porém, devido à saturação dos dados (entrevistas seqüenciais em que as respostas não trouxeram novidade conceitual, sendo claramente repetitivas e repetidas), o número de pacientes entrevistados foi reduzido nos serviços SM 3 e SE 4 para, respectivamente, quatro e cinco. 
Tabela 6. Caracterização dos 27 pacientes usuários de drogas com aids e tuberculose entrevistados. São Paulo, Brasil, 2005.

\begin{tabular}{lrr}
\hline \multicolumn{1}{c}{ Dados } & N & \% \\
\hline Sexo & N & \% \\
\hline Masculino & 22 & 81,5 \\
Feminino & 5 & 18,5 \\
Total & 27 & 100,0
\end{tabular}

Faixa Etária

$\begin{array}{lrc}18-25 & 1 & 3,7 \\ 31-35 & 10 & 37,0 \\ 36-40 & 4 & 14,8 \\ 41-45 & 7 & 25,9 \\ 46-50 & 3 & 11,1 \\ 51-55 & 2 & 7,4 \\ \text { Total } & 27 & 100,0\end{array}$

Estado civil

Solteiro $\quad 10 \quad 37,0$

Divorciado/Separado $\quad 7 \quad 25,9$

Casado $\quad 4 \quad 14,8$

União informal $\quad 6 \quad 22,2$

Total $27 \quad 100,0$

Nível Educacional

Ensino Fundamental $\quad 24 \quad 88,8$

Ensino Médio $\quad 3 \quad 11,2$

Total $27 \quad 100,0$

A maioria dos pacientes entrevistados foi composta de homens (81,5\%); importante destacar que, tanto na tuberculose como na aids, há o predomínio de pacientes do sexo masculino como população mais vulnerável e prevalente. Pesquisadores como MURAI (2000), ao avaliar o perfil epidemiológico dos pacientes com tuberculose atendidos em hospital universitário, obteve o total de $62,7 \%$ do sexo masculino. Numa pesquisa de avaliação de adesão aos ARV por pacientes com HIV/Aids, 72,5\% eram homens e 27,5\% eram mulheres.

KERR-PONTES et al (1997) analisaram pacientes com co-infecção aidstuberculose no Nordeste brasileiro, e a proporção de indivíduos com AIDS e tuberculose entre o sexo masculino $(94,7 \%)$ foi significativamente maior que entre o sexo feminino. 
MURAI (2001) também encontrou, porém em Itajaí (sul do país), predominância de casos do sexo masculino.

Portanto, os pacientes entrevistados nesta pesquisa estão próximos do perfil epidemiológico dos pacientes com HIV/Aids, em relação ao quesito gênero, com cerca de $80 \%$ do sexo masculino. Considerando-se que a triagem e a coleta de dados foi realizada em serviços de atendimento a aids, está compatível com os dados do MINISTÉRIO DA SAÚDE (2005a).

A faixa etária predominante observada foi de 31 a 45 anos, portanto abrangendo a população jovem e produtiva do país. Este grupo vem sendo alvo das epidemias de aids e de tuberculose (MINISTÉRIO DA SAÚDE 2005a). Ainda segundo o MINISTÉRIO DA SAÚDE (2005a), chama a atenção o crescimento da incidência de aids nas faixas etárias de 40 a 59 anos entre os homens, atingindo a população do presente estudo. Se forem somados os percentuais encontrados de pacientes com idade de 40 a 59 anos termos $44,4 \%$ dos entrevistados pertencentes a essa faixa etária.

Em pesquisa sobre avaliação de adesão aos ARV em pacientes com HIV/Aids, LIGNANI et al (2001) trabalharam com pacientes com média de idade de 35,5 anos. NOGUEIRA et al (2001), referem-se ao perfil de pacientes com tuberculose num serviço público de saúde do município de São Paulo a faixa etária de 30 a 49 anos (46,8\%).

Considerando-se o perfil de pacientes que abandonam tratamento de tuberculose, FERRER et al (2001) trazem como fator de risco a idade inferior a 45 anos. OKAMURA (2003) em estudo sobre perfil epidemiológico de pacientes com tuberculose atendidos em hospital universitário de SP, teve como resultado a faixa etária mais atingida de 30 a 39 anos (homens). Em estudo de 2003, SONG et. al. Avaliam as características clínicas e epidemiológicas dos pacientes com aids e tuberculose e houve predomínio da faixa etária entre 20 a 39 anos.

Em estudo no Nordeste brasileiro com pacientes co-infectados, KERR-PONTES et al (1997) concluem que não se observou diferença significativa na proporção de casos de aids com tuberculose e sem tuberculose nas diferentes faixas etárias analisadas. MURAI (2000), tem como resultado a predominância dos casos na faixa etária de 20 a 49 anos. 
Portanto, em relação à faixa etária, a população selecionada foi composta por indivíduos com idades consideradas de risco para as duas patologias, aids e tuberculose.

Quanto ao estado civil, os pacientes entrevistados são, em ampla maioria, pessoas sozinhas, num total de $62,9 \%$, somando-se o total de solteiros e separados. Ser solteiro, ou sozinho, é considerado fator predisponente ao abandono do tratamento de tuberculose (CARVALHO et al 2000).

Chama a atenção o observado durante as entrevistas que, dentre os casados e amasiados, 23\% afirmou estar "separado sob o mesmo teto", sem manter relações sexuais com seu parceiro e/ou relatando o objetivo de pretender separar-se em breve. Um paciente ainda sugeriu que o serviço montasse encontro de casais para 'namoro no SAE', o que evidencia a falta de articulação com as Organizações Não-Governamentais. Por exemplo, o Grupo Pela Vidda promove o "Encontro Positivo", em que pessoas soropositivas têm o propósito de se conhecerem e fazer amigos, ou iniciar relacionamentos, desde 1997.

O nível de escolaridade dos pacientes é predominantemente baixo, sendo quase $70 \%$ da amostra com nível fundamental incompleto. Segundo NEMES et al (2004), há relação direta entre baixa escolaridade e dificuldades na adesão, o que também foi encontrado como resultado desta pesquisa. Considera o nível educacional baixo um preditor importante da não-adesão. No Brasil, o nível educacional é considerado um indicador da condição sócio-econômica.

Em estudo de 2003, SONG et. al. avaliam as características clínicas e epidemiológicas dos pacientes com aids e tuberculose, e concluem que a maioria dos indivíduos com este perfil têm menos de oito anos de escolaridade, com baixa qualificação profissional, estando mais suscetíveis às infecções e tendem a apresentar menor adesão ao tratamento.

Em estudo temporal das doenças associadas a aids no Brasil, GUIMARÃES (2000) analisa a co-infecção aids/tuberculose e constata o aumento na incidência de tuberculose entre aqueles com baixa escolaridade (menor que oito anos). A maior incidência esteve entre os analfabetos (30,1\%). Entre 1990 e 1994, houve aumento na incidência de tuberculose neste grupo, com escolarização menor que 8 anos. Segundo o autor, chama a 
atenção a maior incidência de tuberculose entre analfabetos e $1^{\circ}$ grau para todos os anos fato que também ocorre entre indivíduos não-infectados pelo HIV.(....) Deve-se investigar a hipótese de que os benefícios advindos da profilaxia e do tratamento anti-retroviral possam ser diferenciais para diferentes subgrupos, incluindo escolaridade e outras variáveis marcadoras de condições sócio-econômicas. Nesse mesmo estudo, o autor relata uma queda da incidência de tuberculose (de $25,8 \%$ dos períodos de $80-88$ para $17,9 \%$, no período de 98-99), e maior redução entre as mulheres, porém com a região Sudeste mantendo-se com incidência de $27,9 \%$.

Em pesquisa realizada no Nordeste brasileiro, sobre tuberculose associada a aids, KERR-PONTES (1992) observou uma tendência crescente na proporção de co-infecção aids/tuberculose conforme decresce o nível de escolaridade. O pressuposto é que, no Brasil, a escolarização reflita o nível sócio-econômico do sujeito. Segundo a autora, o nível de escolaridade de determinado segmento social tem sido utilizado, tradicionalmente, como um dos indicadores de nível socioeconômico, especialmente quando não se dispõe de outros indicadores mais precisos.

Na pesquisa de KERR-PONTES (1992), procurou-se analisar se a proporção de coinfecções aids/tuberculose seria maior entre os pacientes com menor nível de escolaridade que, por sua vez, teriam um nível sócio-econômico menor. O resultado foi o seguinte: utilizando-se o teste qui-quadrado para tendência de proporções (ROSNER, 1995), observou-se tendência crescente da presença da tuberculose entre os casos de AIDS conforme decresce o nível de escolaridade dos casos. A grande freqüência de casos com baixa escolaridade entre os casos de aids e tuberculose $(55,6 \%)$ também parece refletir a tendência apresentada por todos os casos de aids em diferentes regiões do País. Os casos tendem a se concentrar, principalmente, no atual estágio da epidemia, entre segmentos sociais de nível socioeconômico mais baixo (KERR-PONTES, 1992; Ceará, Secretaria, 1993). 
Em resumo, os pacientes desta pesquisa são predominantemente do sexo masculino, com idade entre 18 e 45 anos, sendo quase $70 \%$ dos entrevistados sozinhos (solteiros, separados ou divorciados), com nível de escolaridade baixo (quase $70 \%$ com nível fundamental incompleto), e infecção pelo HIV em torno de 10 anos. Em relação à adesão ao tratamento de aids, $66,7 \%$ do total de pacientes entrevistados relataram já terem abandonado, enquanto 33,3\% abandonaram o tratamento de tuberculose. Quanto às interrupções, 70,4\% relataram interromper (pular doses, parar alguns dias, semanas ou até três meses) o tratamento atual de aids.

Segundo FERRER et al (2001), o perfil dos pacientes que abandonam o tratamento de tuberculose é de pertencer ao sexo masculino, idade inferior a 45 anos, solteiro, baixa escolaridade, sem trabalho estável e alcoolista, perfil compatível com o dos pacientes selecionados para esta pesquisa.

\subsection{Padronização e codificação inicial do material coletado}

Todas as entrevistas transcritas foram padronizadas: as perguntas em fonte normal e as respostas em itálico, espaço entre linhas 1,5, fonte Times New Roman 12, numeração de páginas no canto inferior direito e identificação da entrevista no rodapé em todas as páginas. Foram codificadas seguindo números que foram aleatoriamente atribuídos aos serviços, junto à categoria do entrevistado (paciente/ profissional de saúde), e o número da entrevista em si.

- $\quad$ PAC $=$ paciente/ PSAU $=$ profissional de saúde.

- $\mathrm{SM}=$ Serviço Municipal.

- $\mathrm{SE}=$ Serviço Estadual.

Por exemplo:

- $\quad$ SM1 EP PAC 01 = Serviço Municipal 01, Entrevista em Profundidade, Paciente $\mathrm{N}^{\mathrm{o}} 01$.

- $\quad$ SM2 EP PSAU 01 = Serviço Municipal 01, Profissional de Saúde - N$^{o} 01$.

A numeração seguiu a ordem cronológica da realização das entrevistas. Todas as fitas e transcrições integrais estão sob a guarda da pesquisadora e compõem o banco de dados desta pesquisa. 


\subsection{Metodologia de análise dos dados:}

\subsubsection{Módulos de análise:}

Na metodologia RARE (NEEDLE 2002) são obtidos pelo menos três tipos de dados: os resultados das entrevistas (realizadas com roteiros semi-estruturados), as informações trazidas nos mapeamentos e observações e o diário de campo das entrevistadoras.

As respostas dadas pelos pacientes entrevistados às questões da parte II (incluindo as sondagens) foram tabuladas por palavras-chave e sua freqüência analisada para uma aproximação inicial dos dados, conhecimento preliminar dos temas consensuais, contraditórios e dados novos do estudo. No segundo momento, foram organizados blocos temáticos em categorias e sub-categorias, como detalhado abaixo. $\mathrm{Na}$ Análise Qualitativa com a metodologia RARE (NEEDLE 2002), trechos das entrevistas (chamados quodes) são triangulados com os trechos das observações e mapeamentos, com objetivo de compreender:

- os consensos;

- $\quad$ as crenças e os obstáculos (fatores de vulnerabilidade);

- as contradições;

- os fatores de proteção;

- variabilidade.

\subsubsection{Organização das grandes categorias e sub-categorias de análise:}

As etapas da análise qualitativa e a estrutura de codificação dos dados foram os seguintes: após a leitura de cada uma das entrevistas transcritas dos pacientes e profissionais de saúde (médicos e não-médicos), por serviço, foi feita a triangulação com a leitura dos diários de campo das entrevistadoras.

Em seguida, foram organizados os blocos temáticos principais, com unidades de análise temática, no primeiro momento com uma única categoria de entrevistados - por exemplo, tudo o que todos os pacientes disseram a respeito de TUBERCULOSE consensos, contradições, fatos novos. Depois, tudo o que todos os profissionais de saúde disseram a respeito do mesmo tema era sistematizado e analisado com a mesma perspectiva. Finalmente, a estruturação das sub-categorias, em função da quantidade de referências, ou intensidade das contradições, ou ainda especificidade de conteúdo. 
As categorias e sub-categorias de análise dos conteúdos das entrevistas dos pacientes, profissionais de saúde e serviços compõem os Anexos 7, 8 e 9 respectivamente. Os dados de caracterização dos pacientes e dos profissionais de saúde foram codificados em software SPSS (versão 11.0) e compõem os anexos 10 e 11.

Após a minuciosa análise temática, foram escolhidos os temas considerados mais relevantes para o presente estudo:

1) A questão da adesão propriamente dita, com dados sobre abandono dos tratamentos de aids e tuberculose, vínculo destes abandonos relatados com uso de drogas e,

2) A questão da tuberculose - compreendendo uma análise descritiva do atendimento a tuberculose nos quatro serviços de DST/Aids pesquisados e conhecimentos dos profissionais de saúde acerca da tuberculose multidrogarresistente.

Considerando-se que os dados coletados não se esgotam na realização de uma única pesquisa, o banco de dados está disponibilizado para realização de novos estudos. 


\section{RESULTADOS E DISCUSSÃO}

\subsection{ADESÃO}

Os pressupostos teóricos da adesão foram apresentados em detalhes no Capítulo 1, e neste capítulo será apresentada a análise do que interfere na adesão entre os pacientes com aids, tuberculose e usuários de drogas participantes do estudo.

\subsubsection{Fatores que influenciam na adesão ao tratamento:}

Vários fatores interferem na adesão ao tratamento, como as características do paciente, a relação entre ele e o profissional de saúde, o tipo de tratamento e a qualidade do serviço (SUMARTOJO 1993).

Em relação à tuberculose, segundo a Organização Mundial de Saúde, a literatura descreve mais de 200 variáveis associadas ao abandono do tratamento. Vários fatores são inalteráveis, como por exemplo gênero e faixa etária. Porém fatores sócio-econômicos e demográficos não explicam porque alguns pacientes aderem ao tratamento de tuberculose a despeito de terem várias características desfavoráveis. Aparentemente, têm como motivação completar o tratamento e conseguir a cura (apud DICK et al 1996).

Segundo a WHO (2003), em termos de controle da tuberculose, a adesão ao tratamento pode ser definida como o quanto da ingestão de medicamentos coincide com o tratamento prescrito. Na tuberculose pode ser medida, por exemplo, pela taxa de cura, como um indicador de sucesso.

Em pesquisa sobre não-adesão ao tratamento de tuberculose, BRANCO et al (1999) consideram grave problema de saúde pública o abandono do tratamento antes de completar os seis meses necessários, além da irregularidade no uso das medicações em muitas regiões do país. Nesta pesquisa, o desaparecimento dos primeiros sintomas é fator relevante para o abandono, pois os pacientes consideram-se curados, além da inadequada relação médicopaciente, ausência de orientação ao paciente sobre sua doença e forma de tratamento.

Em estudo realizado em São Paulo no período entre 1995 e 1997, foram comparados pacientes que abandonaram o tratamento de tuberculose e pacientes que não o abandonaram (controle). Concluiu-se que a participação em grupos educativos favoreceu o 
não-abandono, e o fato do paciente ser do sexo masculino, fumar tabaco, ser alcoolista, usa drogas, ter fatores de risco para HIV e internação prévia foram considerados variáveis relacionadas ao abandono (RIBEIRO et al 2000). Quanto à adesão entre co-infectados usuários de drogas, os profissionais de saúde afirmam que são vários e diversos os fatores que podem prejudicar o processo:

- Não se pode dizer que tem um, dois fatores que prejudicam a adesão. É o conjunto. São fatores em conjunto que ajudam ou não ao paciente (médica).

- Ah.... tem algumas coisas bem específicas, mas não tem 'este' ou 'aquele' fator (psicóloga).

- Adesão... é adesão à vida, então é muita coisa que interfere, não dá pra apontar um fator e dizer "é este", seria no mínimo incompleto, porque o sujeito que tem aids, que tem o vírus, ele tem uma vida que é muito mais ampla do que aquele diagnóstico. Então tem que analisar todos os fatores, ver o que é melhor, o que é pior... (psicóloga).

Segundo NEMES et al (2004), os preditores de não-adesão potencial ao tratamento da aids seriam:

- características pessoais dos pacientes: idade, sexo, risco de transmissão e nível de alfabetização;

- características do serviço de saúde e a relação com a assistência recebida: nível do cuidado assistencial, número de pacientes, prévia não-adesão nos últimos seis meses e consultas perdidas no mesmo período;

- características do tratamento: tempo de terapia anti-retroviral, número de pílulas prescritas, provável lipodistrofia e dieta.

Os resultados obtidos junto à população selecionada confirmam esses preditores como importantes na adesão.

A faixa etária dos pacientes selecionados para este estudo abrange pessoas com idade média de 35 anos, do sexo masculino e baixa escolarização e, portanto, apresenta vários fatores preditores de não-adesão. Quase 70\% dos entrevistados relataram já terem abandonado o tratamento de aids, como apresentado na tabela abaixo. 
Tabela 7. Número e freqüência de pacientes entrevistados nos quatro serviços de saúde de São Paulo, segundo abandono do tratamento da aids, 2005.

\begin{tabular}{ccc}
\hline $\begin{array}{c}\text { Já abandonou o tratamento } \\
\text { de aids? }\end{array}$ & N & Freqüência \\
\hline Sim & 18 & 66,7 \\
Não & 9 & 33,3 \\
Total & 27 & 100,0 \\
\hline
\end{tabular}

Tabela 8. Número e freqüência de pacientes entrevistados nos quatro serviços de saúde de São Paulo, segundo número de interrupções do tratamento da aids, 2005.

\begin{tabular}{lcc}
\hline Número de interrupções & $\mathrm{N}$ & Freqüência \\
\hline Nunca interrompeu & 8 & 29,6 \\
Uma vez & 1 & 3,7 \\
Duas vezes & 2 & 7,4 \\
Não se lembra quantas vezes & 16 & 59,3 \\
Total & 27 & 100,0 \\
\hline
\end{tabular}

Nesta pesquisa, todos os pacientes abandonaram tratamento de tuberculose em período anterior ao da realização das entrevistas (66,7\% um abandono, 25,9\% dois abandonos, 7,4\% três abandonos). Um dos fatores mencionados foi o número de comprimidos, uma vez que todos tiveram tuberculose como infecção oportunista do quadro de aids. Em relação ao abandono do tratamento da aids, os índices entre os pacientes entrevistados, nos quatro serviços, foram todos superiores a $60 \%$.

Segundo NEMES et al (2004), são preditores de não-adesão referentes ao serviço de saúde os serviços com 100 pacientes ou menos e a perda de consultas.

Neste estudo, os quatro serviços pesquisados têm mais de 100 pacientes em atendimento. Em relação à perda de consultas, não apresentam mecanismos de busca de faltantes estruturados e padronizados. No SE4, existe envio de telegrama e eventualmente é feito um telefonema após a terceira ausência consecutiva não-justificada de um paciente à sua consulta. 
Tabela 9. Número de pacientes entrevistados nos quatro serviços de saúde de São Paulo, segundo tipo de serviço e abandono de tratamento de aids, 2005.

\begin{tabular}{|c|c|c|c|c|c|c|}
\hline \multirow[t]{2}{*}{ Serviço } & \multicolumn{4}{|c|}{$\begin{array}{c}\text { Já abandonou o tratamento } \\
\text { de HIV/Aids? }\end{array}$} & \multicolumn{2}{|c|}{ Total } \\
\hline & Sim & $\%$ & Não & $\%$ & $\mathrm{~N}$ & $\%$ \\
\hline SM1 & 5 & 71,4 & 2 & 28,6 & 7 & 100,0 \\
\hline SM2 & 7 & 63,6 & 4 & 36,4 & 11 & 100,0 \\
\hline SM3 & 3 & 75,0 & 1 & 25,0 & 4 & 100,0 \\
\hline SE4 & 3 & 60,0 & 2 & 40,0 & 5 & 100,0 \\
\hline Total & 18 & 66,7 & 9 & 33,3 & 27 & 100,0 \\
\hline
\end{tabular}

Esses números refletem o quanto esta população selecionada, nos serviços escolhidos, composta por pacientes com co-infecção aids/tuberculose e usuários de drogas têm alto índice de abandono do tratamento de aids. Os pacientes foram entrevistados nos serviços aos quais estavam vinculados naquele momento, sem especificações de terem sido sempre atendidos ali.

Importante destacar que esta é uma estratégia mencionada pelos pacientes, o fato de trocarem de serviço para conseguirem a mudança de esquema terapêutico, em função da ocorrência de intensos efeitos colaterais. Os trechos a seguir ilustram esse problema:

- Às vezes eu passo muito mal, aí peço pro médico me dar outro remédio, trocar o esquema.... se ele não troca, eu vou para o Emílio Ribas, vou pra outro serviço, mas não continuo passando mal.

- Eu preciso trabalhar. Se eu tomo o remédio de manhã, em dez, quinze minutos, preciso ir ao banheiro. Se estou no ônibus, tenho que descer. Então, eu falo, eu quero outro remédio, mas o médico diz que precisa ser esse, que não tem outro e tal. Aí eu vou em outro serviço, faço de novo...

Algumas razões podem ser pensadas em relação ao alto índice relatado de abandonos, como por exemplo, a mudança de serviços, o fato destes pacientes pertencerem a regiões da periferia de São Paulo: uma população pobre, com baixa escolaridade e sem condições de compreensão adequada dos esquemas terapêuticos, sem alimentação correta pertencerem a grupos mais vulneráveis (ex-presidiários, menores reclusos, travestis) freqüentando o serviço. Pertencem ao perfil que traz características já referidas na literatura como preditoras de não-adesão e de fato apresentam um índice elevado de abandonos de tratamento de aids. 
DI GIRÓLAMO (2000), em estudo sobre a influência do serviço de saúde na adesão dos usuários portadores de HIV/Aids de um centro de referência do município de São Paulo, onde $71 \%$ dos pacientes com aids eram considerados aderidos ao serviço, e $29 \%$ não aderidos; avalia que a denominada 'acessibilidade funcional' (bom vínculo e relação com profissionais de saúde) foi preponderante na adesão ao serviço em relação à denominada 'acessibilidade geográfica'.

Entretanto, os profissionais de saúde e pacientes entrevistados consideram importante a questão do acesso e transporte.

- $\quad$ se não tenho dinheiro para condução, não tenho quem me leve, não tenho como ir para o serviço pegar remédio;

- às vezes pego o vale transporte de uma amiga, mas não é sempre que dá;

- o serviço cortou meu vale transporte porque eu sarei, não tinha como ir, parei.

Tabela 10. Abandono do tratamento atual para tuberculose, segundo o total de pacientes entrevistados nos quatro serviços de saúde de São Paulo. São Paulo, 2005.

\begin{tabular}{lcc}
\hline & $\mathrm{N}$ & $\%$ \\
\hline Sim & 9 & 33,3 \\
Não & 14 & 51,9 \\
Não informado & 3 & 11,1 \\
Aguarda tratamento & 1 & 3,7 \\
Total & 27 & 100,0 \\
\hline
\end{tabular}

Tabela 11. Abandono do tratamento atual para tuberculose, segundo cada um dos serviços pesquisados. São Paulo, 2005.

\begin{tabular}{cccccc|c|cc}
\hline Serviço & \multicolumn{7}{c}{$\begin{array}{c}\text { Já abandonou o tratamento } \\
\text { de Tuberculose Atual }\end{array}$} \\
\hline & Sim & $\%$ & Não & $\%$ & $\begin{array}{c}\text { Não } \\
\text { informou }\end{array}$ & $\%$ & $\begin{array}{c}\text { Aguarda } \\
\text { tratamento }\end{array}$ \\
SM1 & 2 & 28,6 & 3 & 42,9 & 2 & 28,6 & - & - \\
SM2 & 6 & 54,5 & 4 & 36,4 & 1 & 9,1 & - & - \\
SM3 & 0 & 0,0 & 4 & 100 & 0 & 0,0 & - & - \\
SE4 & 1 & 20,0 & 3 & 60,0 & - & - & 1 & 20,0 \\
total & 9 & 33,3 & 14 & 51,9 & 3 & 11,1 & 1 & 3,7 \\
\hline
\end{tabular}


O índice de abandono do tratamento de tuberculose relatado pelo total de pacientes entrevistados, 33,3\%, é próximo ao encontrado por DEHEINZELIN et. al (1996), em estudo de avaliação dos fatores preditivos de abandono de tratamento de tuberculose, que obteve uma taxa de abandono de 33,9\% - que foi considerada altíssima em comparação com a média de 12,9\% apontada pelo Ministério da Saúde. A população pesquisada era de pacientes com tuberculose, sem aids e sem uso de drogas.

Segundo FERRER et al (2001), em estudo prospectivo para avaliar a adesão ao tratamento para tuberculose, as características das pessoas que abandonaram o tratamento e as causas do abandono, a porcentagem de abandono foi de 11,5\% (mais próximo do preconizado pelo Ministério da Saúde). O perfil dos pacientes que abandonaram o tratamento é de homens, com idade inferior a 45 anos, baixa escolaridade, sem trabalho fixo e com uso de drogas, ou seja, o mesmo perfil da população aqui estudada.

OLIVEIRA e MOREIRA (2000), ao avaliarem os aspectos relativos a episódios prévios relacionados à recidiva de tuberculose em Campinas/SP, apresentam o índice de abandono de 63\%. Apontam como necessários esforços dirigidos para melhorar a eficiência das unidades de atendimento ao paciente com tuberculose, pois várias irregularidades são decorrentes da "falência” da rotina dos serviços.

Segundo TOLEDO Jr. (1998), é necessária maior divulgação e discussão sobre o problema da tuberculose, bem como a definição de novas estratégias de controle da doença. A descentralização da assistência aos pacientes com tuberculose, o tratamento supervisionado e a volta do ensino da doença nas escolas de medicina contribuirão para o melhor controle da doença.

A proposta de OKAMURA (2003) é de discutirmos a adoção de um sistema de vigilância em tuberculose com base em unidades sentinelas, considerando a dificuldade de registro de dados relevantes sobre a infecção por tuberculose em serviços como hospitais.

O mesmo pode ser pensado em relação aos serviços de DST/Aids, que estão perdendo dados de registro de tuberculose, com prontuários incompletos e falta de monitoramento e mecanismos para averiguar a seqüência dos encaminhamentos realizados.

RIBEIRO et al (2000), ao estudarem indicadores de abandono em doentes com tuberculose, concluem que os pacientes que participaram voluntariamente de grupos 
educativos de sala de espera tinham características semelhantes ao total de pacientes estudados, porém houve menor ocorrência de abandono durante o tratamento.

Em estudo sobre implementação de Tratamento Supervisionado (TS) no controle da tuberculose em Ribeirão Preto, São Paulo, MUNIZ et al (2001) concluem que o TS é uma prática capaz de possibilitar a reorganização do trabalho da equipe de saúde, pois sua inserção no serviço promove redefinição de funções, papéis e reestruturação de rotinas internas, apontando para novas relações no trabalho.

$\mathrm{Na}$ pesquisa de RIBEIRO et al (2000), conclui-se que, tendo-se amplamente disponíveis os meios para diagnóstico e seguimento dos pacientes com tuberculose, todos os esforços possíveis deverão estar concentrados para evitar o abandono, sobretudo nos pacientes de risco, que deverão ter à sua disposição grupos educativos sobre a doença.

Portanto, pode-se inferir que o uso de drogas, a sorologia positiva para HIV, a estrutura atual dos serviços de saúde (a falta de comunicação, de registro preciso de dados, de estratégias para educação continuada em prevenção) podem aumentar significativamente a predisposição do paciente com tuberculose em abandonar seu tratamento, bem como sua atribuída culpa no fracasso do processo.

\section{A) Fatores relativos à complexidade do regime}

O número de comprimidos que precisam ser ingeridos, o esquecimento de doses, a resposta fisiológica aos medicamentos, os efeitos colaterais associados, a presença ou ausência de sintomas e carga viral indetectável são fatores importantes ao se analisar a continuidade do tratamento (WHO 1997).

\section{A.1) Número de comprimidos}

Para os médicos entrevistados, quanto maior o número de comprimidos, maior o número de tomadas por dia, tanto mais complexa a adesão ao tratamento. Isso vem de encontro aos dados da WHO (2003), em que a adesão diminui quanto maior a complexidade do regime de medicamentos (por exemplo, número de pílulas por dose e número de doses por dia).

ELDRED et al (1998) em estudo sobre adesão aos antiretrovirais e profilaxia de pneumonia por $P$. carinii encontraram como resultado que pacientes com prescrição de duas doses diárias ou menos apresentavam melhor adesão ( $\geq 80 \%$ ). Em outro estudo, 
PATERSON et al (2000) tiveram como resultado que o regime de duas doses ao dia estava associado com melhor adesão do que o regime de três doses/dia.

Porém, um profissional trouxe à tona uma questão interessante: que alguns pacientes, mesmo com um reduzido número de comprimidos a ingerir por dia, têm dificuldade de adesão, em contraste a outros que têm número maior de pílulas em seu tratamento.

- [o que ajuda na adesão] Ele ter tesão pela vida. Nada que eu faça, nada que eu invente. Tem gente que está tomando 22 comprimidos e sempre tomou 22 comprimidos e está super feliz com isso, e a vida está boa e bacana. Tem gente que vai tomar só 2 ou 3 comprimidos por dia e não consegue ter adesão a isso. Eu acho que o vale é estar vivo.

Esse dado vem de encontro à literatura, em que um estudo com 1900 participantes coordenado por WENGER et al (1999) demonstrou que a adaptação do regime terapêutico ao estilo de vida e rotina do paciente, bem como a atitude do indivíduo em relação ao tratamento eram melhores preditores de adesão do que a planilha de remédios. Entretanto, faz uma ressalva: um número menor de doses em geral é mais fácil de ser adaptado ao estilo de vida do paciente.

STONE et al (1998) afirmam que os regimes terapêuticos precisam ser simplificados para reduzir o número de pílulas, a freqüência da terapia e minimizar as interações medicamentosas e os efeitos colaterais, e que essa redução de comprimidos aumentaria a adesão.

No presente estudo, os pacientes são unânimes em afirmar que o número de comprimidos prejudica a adesão, como demonstram os trechos a seguir:

- $\quad$ No primeiro mês de tratamento, tomei 600 comprimidos. Já pensou?

- Quanto menos comprimidos, melhor.

- Se tem muito remédio, a gente esquece, a cabeça fica confusa.

- Muitos comprimidos por dia... a gente acaba esquecendo

- Não quero ficar lembrando toda hora, 'sou aidético'

- Tomava três, quatro comprimidos logo cedo, depois do almoço tinha mais uns três, quatro.....era comprimido demais 
- No primeiro mês de tratamento cheguei a tomar 600 comprimidos. Era demais.

\section{A.2) Esquecimento de doses}

Esquecer uma simples dose num período de 28 dias foi considerada um preditor de falência de tratamento. (MONTANER et al 1998). Porém, no presente estudo essa falha (de uma dose) não é sequer mencionada aos profissionais de saúde. Os pacientes não consideram importante ou significativo deixar de tomar doses, como demonstram os trechos a seguir:

- no final de semana, não tem jeito, eu quero tomar minha cervejinha, não tomo remédio

- eu às vezes esqueço, quando vou pra casa da minha enteada, não levo o remédio. Ela não sabe, e eu não levo' (....)’ fico lá uns três, quatro dias

- quando tenho que trabalhar, não tomo remédio. Se eu tomo de manhã, dali dez minutos tenho que descer da condução, o remédio bate forte, onde vou arrumar banheiro na rua? É muito desagradável. Então prefiro ficar sem tomar e poder trabalhar normal.

Para isso, é necessário que se estabeleça vínculo entre paciente e serviço, paciente e profissional de saúde e que o processo de tratamento tenha como bases a avaliação constante e a assiduidade, tanto para as consultas quanto para a realização de exames e orientações diversas.

Nos países em desenvolvimento, as mudanças de responsabilidade nos cuidados com as doenças crônicas nos últimos 50 anos permitiram a implementação de modelos de assistência inadequados às reais necessidades de saúde da população. O sistema de saúde tem o potencial para influenciar a adesão dos pacientes, e controla o acesso à assistência desde o agendamento de consultas até a alocação de recursos.

Nos serviços pesquisados, a avaliação da adesão tem como base a análise dos exames clínicos e laboratoriais, como nos trechos a seguir: 
- Ele (o paciente) conta que tomou direitinho, tal, mas aí os exames dizem outra coisa. (....) Tá na cara que ele não tomou como devia, senão os exames não dariam ruins. Aí eu digo, 'teu exame ta dizendo o contrário', mas ele jura que tomou direito (médica).

- Eu vejo os resultados, pergunto se tem comprimido sobrando, tento pegar de todo lado se o cara ta fazendo o que ta dizendo que faz (médica).

A avaliação da adesão descrita pelos profissionais entrevistados segue os critérios de percepção pessoal (reações do entrevistado às questões feitas em consulta pelo profissional de saúde) e análise dos resultados de exames laboratoriais, que como discutido a seguir, podem não refletir corretamente o uso que o paciente está fazendo dos remédios.

\section{A.3) Adesão e resposta fisiológica}

É consenso entre pacientes e profissionais de saúde que a questão fisiológica interfere de modo direto na adesão: a presença de sintomas, por exemplo, facilita a ingestão de medicamentos, embora a intensidade dos efeitos colaterais dificulte o processo. A questão da eficácia da medicação, a adaptação do organismo às mudanças bioquímicas é ponto importante para refletir sobre adesão.

Muitos pesquisadores acreditavam, no início, que a HAART erradicasse totalmente o vírus do hospedeiro (HO et al 1995; PERELSON, 1996). Entretanto, baixos níveis de replicação viral persistem em pequenas quantidades, mesmo quando a carga viral é indetectável.

Segundo SULEIMAN (2005), mesmo pacientes com 100\% de adesão podem ter má resposta fisiológica. Reforça que os critérios essencialmente clínicos para avaliação da chamada 'boa' adesão (ou seja, análise de exames clínicos e laboratoriais) podem induzir os profissionais a um julgamento incorreto acerca do comportamento do paciente. PATERSON et al (2000) encontraram em suas pesquisas que, mesmo em pacientes com adesão relatada maior de $95 \%, 22 \%$ tiveram falência virológica durante o período de estudo. 
A má-resposta fisiológica à medicação é referida na literatura (WHO 2003) e não é, necessariamente, prova indelével de má adesão ou não-adesão. Em alguns casos, pacientes que relatam ingerir os medicamentos prescritos, seguir a dieta prescrita, alterar hábitos de vida para hábitos saudáveis podem não ter a resposta fisiológica esperada. Ainda segundo SULEIMAN (2005), a aderência ideal é a de 100\% da ingestão de medicamentos e melhoria significativa dos hábitos cotidianos, com dieta saudável, realização de atividades físicas regulares e projetos significativos de vida. O conceito de adesão é trabalhado como um cuidado integral à saúde do paciente, e não apenas ingestão de medicamentos propriamente dita.

Esse é um ponto importante, porque os profissionais entrevistados têm como principal medida de adesão (ao menos uma medida considerada objetiva) a análise clínicolaboratorial, em que a alteração dos indicadores é interpretada como não-adesão.

Dentre os profissionais de saúde entrevistados, a idéia básica é que a resposta clínica e laboratorial seja diretamente proporcional à adesão, como demonstra o trecho selecionado:

- O paciente fala que toma os remédios, mas aí no final da consulta fala 'eu ainda tenho remédio'. Se o remédio é calculado para um período correto, não tem que sobrar. Aí é sinal que não está tomando direito.

As medidas clínicas de adesão (avaliação do paciente em consulta e análise dos exames laboratoriais) trazem informações úteis sobre o comportamento ao paciente porém, apenas uma estimativa. O que se recomenda é a combinação de métodos, desde o auto-relato até medidas objetivas, com avaliação constante do comportamento de adesão (WHO 2003).

- Eu vejo os exames; se ele piorou, eu sei que não está tomando os comprimidos (médico);

- Eu tomei direitinho, não falhei nenhuma. Aí cheguei lá a médica falou um monte, que eu não tinha isso, não tinha aquilo, mas eu tomei direito. Aí encheu, mudei de serviço, vim nesse aqui que ninguém duvida de mim. (paciente, sexo masculino). 


\section{A.4) Efeitos colaterais}

Os efeitos colaterais mais comuns, segundo a descrição dos profissionais de saúde entrevistados e pacientes, são os seguintes:

- Distúrbios gastro-intestinais: vomito, diarréia, dor de estômago. Mal-estar.

- Alergia.

- Dor de cabeça.

- Amortecimento do corpo.

- Enfraquece as relações sexuais, não sente desejo.

- Problema na visão.

- Fraqueza nas pernas.

- O próprio organismo não aceita os medicamentos.

- Lipodistrofia.

Em pesquisa com 120 pacientes com HIV/Aids, LIGNANI et al (2001) obtiveram um índice de $74 \%$ de adesão, e como principal causa de falha considerou os efeitos colaterais. KANAI e CAMARGO (2002) também reforçam a tese que os efeitos colaterais constituem-se em importante barreira à adesão.

Os efeitos colaterais descritos nem sempre são entendidos como tais; muitas vezes, são confundidos com os sintomas das doenças, como demonstram os trechos extraídos de entrevistas com os pacientes:

- Falta informação.

- $\quad$ Não sei se é do remédio ou da doença (...)

- Comecei a tomar e deu a maior fraqueza nas pernas, não conseguia mais andar, fiquei na cadeira de rodas.

- Perdi a vista por causa do remédio, ou doença, sei lá, mas não enxergo mais e não consigo ler qual remédio é da hora.

Um profissional de saúde, médico, mostra-se preocupado com a relação direta entre intensidade de efeitos colaterais e abandono do tratamento.

- O tratamento não pode ser pior do que a doença.

Em pesquisa com médicos do Rio de Janeiro, MALTA et al (2005) refere-se à esquiva de muitos profissionais em dialogar com os pacientes acerca dos possíveis efeitos 
colaterais e da insistência de alguns pacientes em solicitar troca de esquema de medicamentos por conta destes efeitos. Aqui alguns trechos que reforçam essa idéia:

- $\quad$ Meu médico não explicou, não perguntei também.

- Se ela souber que parei pra tomar cachaça, vai querer me tirar os remédios, eu acho.

- Eu disse, preciso mudar, to muito mal, ela disse pra eu agüentar, mas não tava mais agüentando, aí fui pra outro serviço e comecei tudo de novo, com outra pessoa. Não ajudou muito, mas acho que melhorei um pouco, mas pelo menos mudei o esquema.

No presente estudo, pelo depoimento dos pacientes e dos próprios profissionais médicos entrevistados, não é conduta padronizada apresentarem de modo direto os possíveis efeitos colaterais para os pacientes; colocam-se à disposição dos pacientes para 'quaisquer problemas', porém existe uma dinâmica no serviço em que a enfermeira faz uma triagem nos corredores, e quando o paciente tem queixa sobre efeitos colaterais, faz uma consulta de enfermagem.

Essa triagem tem como objetivo liberar o tempo do médico para outras consultas, porém dificulta a relação direta do paciente com o médico.

- A médica fala assim: qualquer coisa, me procura. Aí eu vou, fico um tempão esperando no corredor, vem a enfermeira perguntar o que que eu quero, aí eu falo, ela me leva pra sala, ou fala ali mesmo na frente de todo mundo....não dá, não dá.

Em relação à lipodistrofia, há consenso entre os profissionais de saúde e pacientes de que é um importante fator de não-adesão:

- Deforma o rosto do sujeito, o corpo, é a nova cara da aids - nem tão nova assim, mas você que é da área bate o olho e vê, esse cara ta com aids, ta tomando remédio (psicóloga);

- É uma luta, porque às vezes o cara vai bem, ta reagindo direitinho e tal, começa a mudar o corpo, começa a sentir a feiúra batendo, some, não trata, não faz nada. (médico);

- Por isso montamos aqui um grupo para atividades físicas, pra amenizar um pouco essa coisa da lipodistrofia, porque deforma 
mesmo, é horrível, a pessoa se vê e fala 'tô aidética', sem dó nem piedade (terapeuta ocupacional)

- No grupo, as pessoas ficam mais tranqüilas, vêem que o calo dos outros também dói, às vezes até acha que nem ta tão mal assim... por isso aqui eles fazem amigos, no final do mês tem bolo pros aniversariantes, eles celebram a vida mesmo com essa carga toda que a lipodistrofia denuncia no corpo deles (psicóloga)

- Sem bunda, com aquela corcova de bicho nas costas, ninguém vai querer nem me olhar! Então parei mesmo o remédio (paciente);

- Eu já me trato há mais de 15 anos, querida, então conheço meu organismo, quer dizer, pensei que conhecesse... aí fiz uns exames, tava tudo ótimo,tava todo monstro com a lipodistrofia, aí parei tudo, né?, dar uma chance pro corpinho melhorar. Dali dois, três meses, tive a pior tuberculose do mundo, fui pro inferno, quase morri. Ainda bem que pude tomar outro tipo de esquema e sarei, senão não tava aqui pra te contar essa história (paciente).

- É horrível, porque você fica com as pernas fininhas, aquela cara encovada, todo mundo olha pra você e diz, 'aidético lazarento', tem mãe que puxa a criancinha, sabe?, numas de horror? Então desanima, porque você nem se sente bem direito, físico, e ainda tem que agüentar esses desaforos (paciente).

- Comprei mesmo, peito e bunda, que o remédio me tirou. Comprei, paguei, agora to na fila do metacrilato, quero ficar com a cara cheinha, fico linda, porque além de japonesa, ter aids, que a família vai dizer? (paciente).

\section{A.5) Ausência de sintomas}

Se o paciente apresenta intensos efeitos colaterais, aumenta a chance dele não-aderir e abandonar a medicação.

- Se eu fico pior com o remédio do que sem... pra quê vou tomar?

- Eu não sinto nada, tomo o remédio e fico com dor de cabeça. Não 
tomo e fico bom.

- Eu tô me sentindo assim, mais ou menos bem... aí tomo o remédio e fico um lixo, não consigo sair da cama, ou então fico .. assim... mal dos intestinos, entende? Fico indo no banheiro direto, não acho que ta direito eu ficar bom, tomar remédio e ficar mal. Então não tomo.

É um desafio para o profissional de saúde pensar em como poderia manejar esses sintomas, decorrentes dos efeitos colaterais, se muitas vezes não há medicamentos disponíveis na rede (por exemplo, um analgésico para cefaléia) para fornecimento, e o paciente não dispõe de recursos para adquiri-lo.

\section{A.6) Carga viral indetectável}

A carga viral indetectável é compreendida pelos pacientes, em especial por aqueles com mais de cinco anos de tratamento de aids, como sinônimo de cura.

[o que dificulta a adesão?\}

- A carga viral indetectável... vou tomar remédio pra quê, se tô curado? (paciente, sexo masculino, 6 anos de tratamento de aids)

- Ah......quando deu essa carga indetectável aí... vi que tava curado.... então, não vou ficar passando mal com esses remédios todos, deixa pra quem precisa mais.(paciente, sexo masculino, 12 anos de tratamento de aids)

- Eu já fiz vários e vários testes... quando deu carga viral zerada, minha filha, não quis nem saber de mais nada! Só que depois de 4 meses fiquei mal, tive que voltar, e com o maior medo da médica. Ela quase me bateu. Mas tinha razão, né?, eu esculhambei.(paciente sexo feminino, 8 anos de tratamento de aids).

Pacientes com muito tempo de tratamento têm a predisposição para não-adesão, como está referido na literatura. Nestes trechos, fica visível que o paciente, com algum conhecimento técnico sobre a própria doença, ao menor sinal do que considera cura, prioriza largar os remédios - e larga também todo acompanhamento, exames, vínculo com o serviço de saúde. Os profissionais de saúde também identificam esse problema: 
- Os pacientes consideram a carga indetectável como sinônimo de cura, e deixam de tomar os remédios (médica).

- É um desafio explicar que eles precisam continuar tomando o remédio mesmo sem sentir nada, que o vírus isso, o vírus aquilo, que se não tomar pode piorar, mas eles não acreditam. Aí ou param mesmo, ficam alguns meses fora, sem qualquer contato. Aí voltam péssimos, arrependidos, envergonhados. E outros que vêm de outro serviço, porque queriam parar e o médico de lá não quis, essas coisas (médica infectologista).

\section{B) Aspectos referentes ao contexto de vida do paciente:}

Dentre os pacientes entrevistados, 82,9\% estavam desempregados, vivendo de "bicos" e sem estabilidade sócio-econômica, o que pode ser considerado um agravante em suas condições de adesão.

Em estudo de 2003, CARVALHO et al concluem que idade, escolaridade, situação de emprego, rendas pessoal e familiar, uso de substâncias ilícitas, estrutura familiar e/ou comunitária, presença de infecção oportunista no momento do diagnóstico e ocorrência de efeitos colaterais relacionados à terapia seriam fatores significativamente associados à baixa aderência.

A tuberculose, em geral, afeta pessoas que estão em situação de pobreza, como os moradores de rua, desempregados e pobres. A falta de uma rede social de apoio e as circunstâncias caóticas de vida (ausência de rotina) são fatores que criam um meio desfavorável à adesão ao tratamento de tuberculose (LIEFOOGHE 1995).

\section{B.1) Dependência química}

Para os profissionais de saúde entrevistados, o fato do paciente ser dependente químico (dependência de álcool e uso de drogas) interfere de modo negativo na adesão, o que está de acordo com a WHO (2003).

Segundo MURAI (2001), o uso de drogas de abuso está associado ao abandono do tratamento de aids. Confirmou a influência da aids sobre o perfil epidemiológico da tuberculose, modificando-a em relação a forma clínica, idade, proporção de casos bacilíferos, de curas e de abandonos de tratamento. $\mathrm{O}$ uso de psicoativos foi o fator de 
maior risco para o abandono do tratamento, superando o abuso de álcool e a co-infecção pelo HIV.

Segundo OROZCO et al (1998), num estudo de coorte de 129 doentes de tuberculose (dos quais 13 não aderiram e abandonaram o tratamento antes do término) $o$ consumo de álcool é um dos fatores predisponentes à não-adesão ao tratamento da tuberculose.

Os dados aqui obtidos junto à população de pacientes estudada confirmam isso: $81,5 \%$ dos pacientes relatam ter abandonado o tratamento e aids em função do uso de álcool.

CARVALHO et al (2003), em estudo com 150 pacientes atendidos no Hospital-Dia de Brasília, refere-se ao uso de substâncias ilícitas como um fator significativamente associado à baixa adesão, e conclui que as variáveis sócio-econômicas e de hábitos tiveram maior força de associação com o nível de adesão do que as relacionadas com a doença ou com o tratamento.

Dentre os pacientes entrevistados, $74,1 \%$ relataram já terem abandonado o tratamento em função do uso de cocaína.

- O calcanhar de Aquiles da adesão é a dependência química (médico).

- O paciente que sofre de alcoolismo precisa ir para tratamento supervisionado, porque não consegue aderir (médica).

- Os piores e mais difíceis de aderir são os dependentes (médica).

- O que dificulta a adesão? Usuário de droga. São os piores, não vêm, não querem mesmo nada com nada, é um inferno. Eles não querem viver e não querem se tratar, então é sempre dar murro em ponta de faca (enfermeira).

- A pessoa, não é porque usa droga, mas porque tem um estilo de vida caótico, não consegue se organizar para tomar remédio, não consegue se tratar (psicóloga).

- Não é por causa da droga, mas é a questão do esquecimento (psicóloga).

Pode-se perceber nestes trechos a confirmação que, em princípio, ser usuário de drogas já dificulta o próprio atendimento: o profissional de saúde considera todos os 
dependentes como 'piores', 'difíceis de atender'. São pacientes que exigem mais tempo, maior dedicação, capacitação e, como se observou na caracterização da população estudada, os profissionais de saúde entrevistados não têm capacitação específica em dependência química, para compreenderem de outro modo a dinâmica dos pacientes usuários de drogas. A temporalidade, zelo pessoal e a espacialidade desses sujeitos é diferente destes mesmos referenciais em pessoas não-dependentes (POMPÉIA 1996).

Isso não precisa ser base para a idéia aparentemente arraigada de que estes pacientes, a priori, serão difíceis, complicados, etc. Os pacientes usuários de drogas podem ter uma vivência diferenciada do tempo, ora urgente, ora letárgico, o zelo pessoal muitas vezes é comprometido e sua noção espacial também: por isso muitas vezes parecem 'atrapalhados', ou 'sob efeito da droga', pois muitas alterações ficam incorporadas a seu modo-de-ser e agir mesmo sem a droga.

Três profissionais de saúde, um médico, uma enfermeira e uma terapeuta ocupacional, fazem a ressalva: ser dependente químico não é sinônimo de ser não-aderente, mas é exceção.

- Tem pacientes que não são dependentes químicos e não aderem (médico)

- São poucos (os dependentes químicos) que aderem bem, em geral quando estão se tratando do vício, mas a maioria já chega gritando, xingando, quer ser atendido na hora, senão dá escândalo... horrível, eles adoram dar escândalo, ainda mais os travestis... tudo é “direito”, “cidadania”, eles ficam aí ouvindo besteira e na hora de respeitar a gente não respeitam (enfermeira).

- Teve pacientes usuários de álcool em situação de rua que conseguiram começar e terminar o tratamento - são fenômenos (terapeuta ocupacional).

O perfil de comportamento para adesão estaria pré-determinado no estereótipo, de que os usuários de drogas e moradores que têm boa adesão são considerados exceções, o que poderia ser modificado com a introdução nos serviços do Plano Individual de Adesão: cada paciente teria um plano adequado a seu estilo de vida, e os parâmetros para avaliação poderiam ser construídos na relação paciente-profissional de saúde. 


\section{B.2.)Tempo de infecção pelo HIV}

Tabela 12. Número e freqüência de pacientes entrevistados nos quatro serviços de saúde de São Paulo, segundo tempo de infecção e abandono do tratamento da aids. São Paulo, 2005.

\begin{tabular}{cccc}
\hline $\begin{array}{c}\text { Tempo de infecção pelo HIV } \\
\text { (em anos) }\end{array}$ & $\begin{array}{c}\text { Abandono de tratamento da } \\
\text { aids }\end{array}$ & Total \\
\hline & Sim & Não & \\
\hline $1-5$ & 5 & 3 & 8 \\
$6-10$ & 7 & 1 & 8 \\
$11-15$ & 3 & 2 & 5 \\
$16-20$ & 3 & 1 & 4 \\
$21-25$ & - & 1 & 1 \\
Não lembra & - & 1 & 1 \\
Total & 18 & 9 & 27 \\
\hline
\end{tabular}

A população de pacientes entrevistados tem 59,2\% com 10 anos ou menos de infecção pelo HIV, e 40,8\% com mais de 11 anos de infecção pelo HIV. NEMES et al (2004) em estudo multicêntrico, considera que ter sabidamente a infecção pelo HIV há seis anos e meio ou mais é considerado um aspecto dificultador da adesão.

Em estudo realizado em 2003, CARVALHO et al pesquisaram fatores para boa ou má adesão ao tratamento antiretroviral, em Brasília/DF. Dentre os fatores analisados, verificou-se se o tempo de infecção pelo HIV seria uma variável significativa para se avaliar adesão ao tratamento.

No presente estudo, $37 \%$ dos pacientes têm intervalo entre diagnóstico e início de tratamento superior a dez anos, o que os predispõe a uma pior adesão do que pacientes recém-diagnosticados. Acrescentando- se a este fator o tempo de tratamento de aids e o uso de drogas, têm-se um aumento na predisposição ao abandono e à não-adesão.

\section{B.3.) Tempo de tratamento de aids}

Segundo NEMES et al (2004), os pacientes com aids com mais de seis anos e meio de tratamento teriam maior probabilidade de serem não-aderentes.

No presente estudo, como mostra a tabela abaixo, um total de 37,0\% dos pacientes com mais de seis anos de tratamento já o abandonaram, em proporção próxima aos pacientes com menos de seis anos de tratamento (32,6\%). Como o estudo de NEMES et al foi realizado com pacientes com aids, sem co-infecção ou uso de drogas como critério para seleção, é importante ressaltar esse aspecto na análise deste dado. 
Tabela 13 - Tempo de tratamento em aids e referência a abandono, pacientes com aids/tuberculose, usuários de drogas. São Paulo, 2005.

\begin{tabular}{cccc}
\hline $\begin{array}{c}\text { Tempo de tratamento } \\
\text { (anos) }\end{array}$ & $\begin{array}{l}\text { Abandono de } \\
\text { tratamento de aids }\end{array}$ & Total \\
\hline & Sim & Não & \\
$1-5$ & 7 & 7 & 14 \\
$6-10$ & 8 & 1 & 9 \\
$16-20$ & 1 & - & 1 \\
Não lembra & 2 & 1 & 3 \\
Total & 18 & 9 & 27 \\
\hline
\end{tabular}

Seriam necessários estudos quantitativos para uma definição, porém pode-se inferir que o tempo de tratamento, para esta população, é tão ou mais importante do que o fato de serem usuários de drogas e co-infectados com tuberculose, no que se refere a adesão e abandono.

\section{B.4) Condições psíquicas e cognitivas do paciente}

Segundo a WHO (2003), o melhor tratamento pode falir se o paciente não toma o medicamentos como prescrito ou se recusa a tomar. Os fatores psicológicos são considerados muito importantes para análise da adesão.

A perda de esperança e sentimentos negativos pode reduzir a motivação para a pessoa se tratar e podem influenciar a condição do paciente acompanhar as instruções, que são complexas. Esses dados são semelhantes a outros, de estudos sobre outras condições crônicas, que demonstraram uma relação entre adesão e depressão (MORSE, 1991).

Os pacientes entrevistados são unânimes em atribuir as falhas e o desânimo em seus tratamentos a estados depressivos:

- Há 20 dias perdi minha mãe, há 20 dias não tomo remédio;

- Eu fiquei assim, deprimida, tomava um litro, um litro e meio de cachaça por dia, ficava sem remédio, sem banho, sem nada. Não via nada, não queria saber de nada. Aí sarei.

- Quando soube que minha filha de 19 anos estava podre de herpes,me deu vontade de morrer. Já não bastava uma na cada com 
doença? Aí fiquei trancada no quarto, fiquei três meses sem remédio, mas não abandonei.

Os pacientes entrevistados reforçam esse argumento, ante a pergunta o que dificulta a adesão? (extraída a palavra-chave dos trechos):

- Depressão.

- Preconceito.

- Solidão.

- Lembrar todos os dias que sou portador da doença.

- Perdi minha mãe há 20 dias, estou há 20 dias sem remédio.

- Horário.

- A pessoa fica xarope da cabeça.

- Efeitos colaterais.

- Cabeça fica confusa.

- Falta de ânimo.

- $\quad$ Vontade de se matar.

- $\quad$ Não aceitar o diagnóstico, porque a aids é uma doença que não tem limite.

Os profissionais de saúde são unânimes em afirmar que a depressão e a nãoaceitação da doença são fatores importantes no abandono, e dificultam a adesão. Os trechos a seguir ilustram essa idéia:

- Se o paciente não aceitou o diagnóstico, está infeliz, sem tesão por nada, cheio de sentimento de culpa, e eu não aceito isso, não vou ajudar no tratamento dele (médico).

- Se o paciente está infeliz, se tem uma desestruturação familiar, se ele está deprimido, com muito sentimento de culpa, isso atrapalha a adesão dele, sem dúvida (médica).

- Quando ele tem um déficit cognitivo, dificuldade de compreensão das abstrações, baixo nível de escolaridade, dificulta (psicóloga).

- Se o paciente tem QI baixo, dificulta a adesão (psicóloga).

- Se tem problemas psiquiátricos, se está preso, se não tem um cuidador adequado, tudo prejudica a adesão dele (psicóloga). 
Na perspectiva de KANAI e CAMARGO (2002), a aceitação e a adesão com agentes anti-retrovirais parecem estar significativamente associadas à medicação, acreditar no sistema de saúde e na relação interpessoal com os médicos e seus assistentes,e a nãocompreensão das instruções é tida como a mais freqüente causa de falta de adesão.

É desafio dos profissionais de saúde, seja no momento da triagem, aconselhamento, ou mesmo consulta propriamente dita, ter uma anamnese psíquica acurada, para detectar problemas cognitivos e estados de ansiedade e/ou depressão, para encaminhamentos adequados.

\section{C)Fatores relativos ao atendimento em saúde}

Os fatores relativos ao atendimento em saúde referem-se aos serviços propriamente ditos, o tipo de tratamento oferecido, à relação médico-paciente e ao papel da equipe multiprofissional no processo de assistência. No ítem 3 é feita uma análise dos serviços pesquisados em termos de estrutura e atendimento em geral, além da avaliação do atendimento em tuberculose.

O conceito de tratamento supervisionado foi desenvolvido por Wallace Fox em 1950 (apud RAVIGLIONE e PIO 2002) e é atualmente conhecido como DOT - Directly Observed Therapy (ou seja, terapia observada de modo direto).

Essa estratégia foi adotada na década de 60 em países como Índia e China (BAYER e WINKINGSON 1995) e hoje em dia é amplamente recomendada para controle da tuberculose (BASS et al 1994; CHAULK e KAZANDIJAN 1998; ENARSON et al 2000). Ressalta-se que apenas a estratégia de DOT (ou sua versão 'short', curta - DOTS) considerada sem intervenções complementares não é suficiente para melhorar ou garantir a adesão dos pacientes para o tratamento da tuberculose (WHO 2003; MINISTÉRIO DA SAÚDE 2002b).

No presente estudo, apenas $11,1 \%$ dos pacientes entrevistados fizeram tratamento anterior de tuberculose do tipo supervisionado. Considerando-se que esse tratamento é especialmente recomendado a pacientes não-aderentes, é possível inferir que os pacientes com aids, tuberculose e usuários de drogas não são, necessariamente, pacientes com 
dificuldades especiais de adesão. Também é importante destacar que a imprecisão de registros nos serviços sobre abandono de tratamento de tuberculose e mesmo de ARV pode dificultar a avaliação quanto à necessidade de tratamentos supervisionados.

Em relação ao tratamento atual para tuberculose, $48,1 \%$ estão em tratamento supervisionado, o que sinaliza o esforço dos profissionais dos serviços em garantir que o paciente tenha tratamento completo e correto. O auxílio de transporte e o fornecimento da cesta básica são considerados fatores de aumento da adesão entre esses pacientes.

\section{C.1.) Serviços de saúde e tipo de assistência oferecida:}

O serviço público de saúde fornece, no Brasil, os medicamentos antiretrovirais pelo Sistema Único de Saúde (SUS) para todos os pacientes com aids. No início do ano de 2005, houve problemas no fornecimento, o que causou vários transtornos para pacientes e médicos - tanto em relação ao esquema de tratamento já aplicado e utilizado pelo paciente, quanto em relação a mudanças necessárias neste esquema.

- A gente faz um trabalho imenso de conscientização, que não pode falhar o remédio e tal, daí falta...e você tem que interromper, trocar, fazer miséria (médico).

- É um sufoco, porque tem que equacionar, racionar, economizar, aí você vê que a pessoa não pode ficar sem, e não pode dar o remédio. É uma angústia (farmacêutico).

A falta de medicamentos (não apenas antiretrovirais) é apontada como fator importante na não-adesão, como demonstram os trechos a seguir:

- Falta de remédio (médico, psicóloga, paciente).

- Às vezes você tem o remédio caro, mas falta um Imosec de R\$5,00 e você não pode tomar o remédio da aids por causa da diarréia (paciente).

- Não ter o remédio é angustiante: eu (farmacêutico) raciono, divido as doses, faço o que posso para não faltar remédio pra ninguém, mas às vezes falta mesmo. 
Outro fator que dificulta a adesão, segundo os profissionais de saúde entrevistados, é a própria relação do paciente com o serviço:

- O não-acolhimento do paciente (enfermeira).

- Falta uma sala de espera apropriada, não tem grupo educativo (educadora).

- Falta de informação (enfermeira).

- Falta de adesão ao serviço (psicóloga).

- $\quad$ Às vezes o paciente não tem o dinheiro da condução e não pode vir para as consultas. Antes tinha aquele vale-transporte, mas agora (2005) cortaram, o paciente vem como? Vem a pé? Não pode (psicóloga).

\section{C.2) Tratamentos para tuberculose oferecidos nos serviços}

Para se conhecer o significado do tratamento supervisionado para os profissionais de saúde, foram utilizadas as seguintes sondagens, no roteiro:

(a) Fale um pouco sobre o tratamento de tuberculose que é feito neste serviço.

(b) Quais os tratamentos para tuberculose que são oferecidos neste serviço? Comente. As respostas foram relativas aos dois principais tipos de tratamento: o supervisionado e o auto-administrado. O supervisionado é oferecido aos pacientes com histórico de abandono e usuários de drogas. Os trechos que subsidiam esse tema são:

- O tratamento em si é supervisionado. Para alguns, é dada uma quantidade menor ou faz-se um acompanhamento mais de perto daqueles que tem resistência, que já pularam do esquema 01 para outro esquema...(médica)

- $\quad$ Não são todos, porque tenho pacientes que são bem aderentes que não tem essa necessidade de supervisão. Para todos é oferecida a supervisão (médica).

- Tem o paciente que segue direitinho a orientação não precisa ser supervisionado. Tem muitos até que nem querem, porque é difícil para eles virem todos os dias à unidade, mas maioria toma direitinho a medicação (enfermeira). 
PINHO e NOGUEIRA (2001) avaliando o tratamento supervisionado de tuberculose no município de Taboão da Serra, afirmam que a OMS tem instado os países a utilizarem o tratamento supervisionado (TS) em seus programas de tuberculose.

No Brasil, os municípios prioritários têm sido orientados a utilizar a estratégia experimentalmente. Em setembro de 1998, o tratamento supervisionado foi implantado em duas unidades de atendimento, e em janeiro de 1999, em todas as unidades. A conclusão foi que o tratamento supervisionado teve maior efetividade.

No trabalho de COSTA (2000), considera-se o sucesso do tratamento como diretamente proporcional ao enfoque dado sobre o paciente e seu contexto - e não sobre a medicação a ser administrada. A idéia de um tratamento supervisionado, porém em sentido amplo, não restrito a 'fiscalização': a elaboração de um plano terapêutico, não limitado à medicação prescrita, é subsidiada pelos conceitos em saúde da família, para avaliar a evolução e a necessidade de intervenção ou ajustes na prestação de assistência pela equipe responsável.

A prática de medicação supervisionada é protocolada pela Secretaria Municipal da Saúde de Curitiba, e a pesquisa desenvolvida por COSTA (op cit) realizou-se na Unidade de Saúde Moradias da Ordem. Consideram o atendimento diário condição para proximidade e flexibilidade na relação com o paciente, contemplando a garantia do uso da medicação e a participação ativa do usuário durante todo o processo terapêutico.

PINHO (2000) estudou, em Taboão da Serra, 250 casos de tuberculose no período de janeiro de 1998 a dezembro de 1999. As coortes foram classificadas de acordo com a estratégia de tratamento e comparadas segundo suas taxas de sucesso. Destes 250 casos, 92 pacientes optaram pelo Tratamento Supervisionado, dos quais 86,8\% foram curados e apenas quatro abandonaram o tratamento. O TA registrou uma taxa de cura de $83 \%$, com oito abandonos. Concluiu que a implantação do TS promoveu maior efetividade do TA, e melhor desempenho do programa.

Portanto, é possível avaliar que um tratamento, seja auto-administrado ou supervisionado, com enfoque no paciente e não na medicação, tem melhor possibilidade de sucesso e cura do que o tratamento não-cuidado. 
Embora o conceito de tratamento supervisionado seja conhecido no meio médico, existe muita confusão - mesmo entre os profissionais de saúde - a esse respeito. Foram utilizadas as seguintes perguntas, no roteiro para profissionais de saúde:

(a) Frente ao paciente com aids, como vocês fazem para buscar tuberculose? Que tipo de tratamento oferecem?

(b) Como é o tratamento supervisionado? A quem é recomendado, ou indicado para ser feito?

Os trechos das respostas selecionados foram:

- Aqui, como não é feito o tratamento que é preconizado pelo Ministério da Saúde -que é o supervisionado- todos os pacientes daqui fazem o tratamento auto-administrado. Então, é muito difícil fazermos uma avaliação. Em Santo André há um outro tipo de trabalho, trabalho especificamente com TB sem HIV e o tratamento é o supervisionado, então conseguimos ter uma avaliação melhor. No auto-administrado é um pouco complicado porque a gente acredita que realmente não tem uma adesão de 100\%, o tratamento é mais irregular de mais difícil controle e atrapalha bastante o tratamento.

- Estamos quase obrigando, insistimos muito para que o paciente faça o tratamento supervisionado.

- Hoje em dia é que as coisas funcionam assim (supervisionada), mas a gente dá sim (a medicação). Acho que nem todo mundo faz o esquema supervisionada, acho que são só os que não aderem bem ao tratamento, eu acho.Antigamente a medicação era distribuída para todo mundo, mas hoje em dia tem aquele pessoal que não quer aderir daí à doença começa a ficar mais resistente, então está sendo feita a supervisão para esses casos (os que não aderem ao tratamento).

- Nós atendemos, porque tem muita gente de hospital, o estado não distribui esse tipo de medicamento, na farmácia hospitalar não tem, já veio muita gente da Santa Casa com a receita, e daí nós atendemos. Só que nós sempre orientamos a pessoa a procurar o posto para fazer o acompanhamento. 
PINHO e NOGUEIRA (2001) avaliaram se a implantação do tratamento supervisionado influenciou as taxas de sucesso, comparando-o com o Tratamento Autoadministrado, no município de Taboão da Serra, através do estudo de coortes de

Todos os profissionais de saúde afirmam que o tratamento supervisionado é importante ferramenta para auxílio dos pacientes com baixa adesão, moradores de rua, expresidiários e mesmo pacientes com baixa escolaridade.

Os pacientes entrevistados apresentaram diversos tipos de tratamento anterior para tuberculose, como demonstrado na tabela abaixo:

Tabela 14. Tipos de tratamento de tuberculose(s) anterior (es) descritos pelos pacientes entrevistados. São Paulo, 2005.

\begin{tabular}{lll}
\hline $\begin{array}{l}\text { Tipo de tratamento oferecido }- \\
\text { tuberculose anterior }\end{array}$ & Freqüência & $\%$ \\
\hline TS & 3 & 11,1 \\
TA & 5 & 18,5 \\
Não informado & 1 & 3,7 \\
Não houve TB anteriores & 18 & 66,7 \\
Total & 27 & 100,0 \\
\hline
\end{tabular}

Em relação ao tratamento atual para tuberculose, 48,1\% relataram estar em tratamento supervisionado, sendo 18,5\% com internação.

Tabela 15. Tipo de tratamento da Tuberculose atual, segundo pacientes entrevistados. São Paulo, 2005.

\begin{tabular}{lcc}
\hline \multicolumn{1}{c}{ Tipo de tratamento da tuberculose atual } & $\mathrm{N}$ & $\%$ \\
\hline TS & 8 & 29,6 \\
TSI & 5 & 18,5 \\
TA & 12 & 44,4 \\
Não se tratou & $2 *$ & 7,4 \\
Total & 27 & 100,0 \\
\hline
\end{tabular}

Nota explicativa:

TS - Tratamento Supervisionado

TSI - Tratamento de tuberculose Supervisionada com Internação

TA - Tratamento de tuberculose Auto-administrado

* Os dois pacientes que não estavam se tratando mencionaram o esforço dos profissionais de saúde em convencê-los a realizar o tratamento.

Alguns pacientes, quando indagados acerca do tratamento supervisionado, afirmavam fazê-lo. Porém, ao explicar como funcionava, descreviam o tratamento autoadministrado, utilizando a palavra 'supervisão' como sinônimo de fiscalização, como mostram os trechos a seguir: 
- Supervisionado? Faço, sim, minha mãe e meu pai me supervisionam todos os dias, eu tomo a medicação em casa.

- Tomo todo dia os comprimidos em casa, busco aqui os remédios e levo, tenho supervisão em casa.

Segundo a WHO (2003), em estudos com pacientes com tuberculose em países com alta prevalência da doença, ficou demonstrado que o tratamento supervisionado isoladamente não promove ou melhora a adesão. Os resultados reforçam a idéia de que não se pode isolar as intervenções, sem considerar os outros fatores que afetam a adesão, como por exemplo, boa qualidade da comunicação entre paciente e profissionais de saúde, custos de transporte e crenças sobre tuberculose.

Segundo COSTA (2000) em estudo sobre medicação supervisionada em Curitiba, o sucesso do tratamento é diretamente proporcional ao enfoque dado sobre o paciente e seu contexto, e não sobre a medicação a ser administrada. Reitera que o acompanhamento precisa ser flexível, contemplando a garantia do uso da medicação e a participação ativa do usuário durante todo o processo terapêutico, e como estratégia foram utilizados os programas de saúde da família.

Esta é uma estratégia que já existe há muitos anos no Brasil (MINISTÉRIO DA SAÚDE, 2002b) e pode ser mais uma ferramenta para os serviços de DST e Aids, no acompanhamento e orientação dos pacientes com tuberculose.

\section{C.2) Relação médico-paciente}

Segundo a Organização Mundial de Saúde (WHO 2001), a qualidade da relação entre paciente e profissional de saúde é um preditor importante da adesão. Tratamentos efetivos têm como base relações caracterizadas por uma atmosfera de diálogo, com discussão das alternativas terapêuticas, negociação do regime, conversas sobre a adesão, e elaboração conjunta de um plano de acompanhamento.

De acordo com os médicos entrevistados, se o médico não consegue, ou não quer, colocar-se no lugar do paciente e compreender a forma peculiar como este paciente encara a própria vida, a doença e as condições para tratamento, isso é considerado um fator de prejuízo ou dificuldade para adesão, como ilustram os trechos a seguir:

- Se o meu foco de vida é diferente do cara que sentou do outro lado e eu 
não percebo isso, não trato disso com atenção, fica distante.(médico)

- De repente, o cara pode chegar para mim e dizer: "Olha, vai se catar. Eu não vou tomar porra nenhuma". O primeiro sentimento do médico, sentimento humano é dar uma porrada nele. Quer cometer suicídio vai para outro canto, não na minha frente. Lidar com essa diferença do cara que seguramente está dizendo: "Eu não vou fazer isso". Você começa a discutir com ele, porque ele não vai usar. Vai aceitar antes, é claro. Eu não estou conversando com estou conversando com nenhum menino, não há dúvida. É um adulto, sabe onde ele quer que a vida dele ande, talvez você ache que ele saiba. Entender isso e você tentar com ele descobrir o que pode segurar esse cara aqui. Porque se não tiver o que segure, vai acabar morrendo. Vai morrer tomando remédio, vai morrer sem tomar remédio.(médico infectologista)

- Se o tem uma posição de 'ditador'por parte do médico, isso dificulta a adesão do paciente (médico).

Se por um lado, o profissional médico diz, racionalmente, que a posição autoritária dificulta a adesão, por outro lado tem uma forma unilateral de lidar com a diferença: o fato do paciente querer ou não querer se tratar passa pelo vaticínio, "vai morrer tomando remédio, vai morrer sem tomar remédio'. O profissional tem clareza do sentimento que um paciente que não adere provoca. Essa recusa ao tratamento, para o médico, remete diretamente à idéia de que o paciente 'quer morrer'. São médicos que atendem aos pacientes com aids, tuberculose e usuários de drogas. Nega-se ao paciente, por exemplo, o direito de querer morrer. A análise cuidadosa do que está ocorrendo em sua vida, como está sua condição orgânica, os fenômenos psíquicos complexos não são considerados em sua totalidade, e associa-se a não-adesão à morte voluntária. Isso é rejeitado, em lugar de interpretado à luz dos conhecimentos científicos, abrindo possibilidades de intervenções diferenciadas.

Daí a necessidade de capacitação técnica dos profissionais: muitas vezes o usuário de drogas tem dificuldades em aderir a vários setores da vida, não a um tratamento em particular. A abordagem deste paciente na perspectiva do terror, do vaticínio de morte, pode 
apenas aguçar um sentimento auto-destrutivo já arraigado.

Ou nada disso, o preditor de não-adesão refere-se a outro fator que não é identificado de imediato, e fica mais fácil abandonar o tratamento do que abandonar a dependência - pois esta, no mínimo, lhe confere uma identidade social. Talvez fosse benéfico para paciente e profissional de saúde se, em lugar de um julgamento moral dos comportamentos do usuário, analisasse a situação à luz do conhecimento técnico-científico e propusesse uma intervenção mais adequada.

O próprio paciente nem sempre tem a dimensão de risco ou a associação direta 'não-medicação = morte', e às vezes pode estar em processo depressivo ou auto-destrutivo e realmente fazer uso desta informação para abandonar o tratamento.

Em estudo com médicos do Rio de Janeiro, MALTA et al (2005) conclui que a boa comunicação entre paciente e médico sobre o estilo de vida do paciente e preferências pode melhorar a adesão. (....) Em contrapartida, pacientes que recebem informações inadequadas de seus médicos e/ou não compreendem as recomendações e prescrições, são menos propensos a aderir. Médicos que utilizam linguagem excessivamente técnica, ou o baixo nível de escolaridade dos pacientes, e ainda outras barreiras de linguagem, podem se constituir em barreiras para a adesão.

A relação profissional de saúde-paciente é um fator importante na adesão ao tratamento; no presente estudo isso foi demonstrado, pois os pacientes têm características de pobreza, exclusão social, comportamentos de risco, e os profissionais de saúde que os atendem não demonstraram ter a atualização técnico-científica constante que seria necessária para um melhor atendimento destes pacientes na perspectiva de aumento da adesão.

\section{C.3.) Papel dos profissionais não-médicos}

Estes profissionais não apenas auxiliam na comunicação entre pacientes e médicos, em relação ao tratamento em si e em relação à busca ativa de comunicantes na tuberculose, mas trabalham toda parte de aconselhamento e acompanhamento dos pacientes no cotidiano institucional.

Nas respostas à pergunta Por exemplo, quando vem um paciente com AIDS qual é a rotina padrão para se identificar se ele tem tuberculose ou não?, fica explícita essa relação 
com os médicos, com uma especial necessidade de interlocução. Os profissionais auxiliam o paciente para que este se faça ouvir, permitindo que o médico possa atendê-lo da melhor maneira possível.

Os seguintes trechos foram obtidos nas entrevistas:

- E dos nossos pacientes o que estamos organizando no tempo de programa, é que assim... a medida em que o médico já testa, e sempre vai pedindo, a busca ativa é feita dentro da consulta e no pós consulta, que a enfermagem pergunta também, a idéia é estar incentivando sempre, tanto para a auxiliar de enfermagem ou mesmo a enfermeira, perguntar se o paciente está tossindo. Porque às vezes dentro da consulta ele até esquece de falar, a não ser que aquele sintoma já esteja acentuado, tipo ele está com tosse, com sudorese, com algum problema maior, daí ele já fala para o médico (nutricionista).

- Às vezes só quando é uma tosse e ele não percebe, acaba se esquecendo de comentar com o médico, então na pós-consulta estamos tentando fazer com que seja uma pergunta de rotina, para que tenha busca ativa também no pós consulta (psicóloga).

- Porque é uma forma de estar lembrando o entrevistador de perguntar ao usuário e uma questão de estar levantando sempre, fazendo parte até do programa de tuberculose essa pergunta (psicóloga).

Em síntese, os pacientes selecionados para este estudo têm o "tríplice estigma", e seu atendimento poderia ser melhorado com intensificação nas capacitações para ampliar as estratégias de abordagem para uso de drogas e adesão; atenção especial para as falhas, erros e descontinuidades na ingestão de remédios, bem como a estratégia dos pacientes em mudar de médico ou de serviços para mudança de esquema de ARV. Também poderiam ser acrescentados: orientações específicas sobre tuberculose (tratamento, contágio, profilaxia), direitos reprodutivos e sugestão de acompanhamento psicoterápico para melhoria da vida afetiva e sexual. Os grupos para lipodistrofia são de grande ajuda para superação das dificuldades do efeito colateral mais visívele inequivocadamente relacionado a aids. 


\subsection{TUBERCULOSE}

\subsubsection{Atendimento da tuberculose nos serviços de DST/Aids - caracterização dos serviços}

Será apresentada uma breve caracterização dos quatro serviços de DST/Aids selecionados, primeiro em relação à sua estrutura geral, e no segundo momento, quanto ao atendimento da tuberculose. Os trechos das respostas aqui apresentados em itálico representam a transcrição integral e literal do que foi significativo nas respostas dos entrevistados. Para a análise, a codificação para categorização das respostas foi apresentada no capítulo de metodologia. Os resultados são os seguintes:

\section{a) Serviço Municipal 1 - SM1: Serviço de Atendimento Especializado em DST e Aids.}

Segundo informações obtidas no 'site' da prefeitura do Município de São Paulo, os SAE são unidades de saúde que realizam atividades de prevenção, diagnóstico e tratam dos pacientes portadores de várias doenças sexualmente transmissíveis, entre elas o HIV/AIDS. Contam com um pequeno laboratório e uma equipe diversificada de profissionais, incluindo médicos em mais de uma especialidade, psicólogo, nutricionista, assistentes sociais, educadores, entre outros. Todas as unidades funcionam de $2^{a}$ a $6^{a}$ feira, das 7:00 às 19:00 h.

O serviço SM1 tem em seus registros $0 \%$ de abandono ao tratamento de HIV/Aids. Nas entrevistas realizadas, há relatos abandono, que podem ser de pacientes advindos de outros serviços (isso não foi investigado). Ou ainda, mais uma evidência da falha na vigilância da tuberculose, uma vez que neste serviço todos os funcionários são treinados para identificar e encaminhar os casos de tuberculose para tratamento imediato, têm apoio do Programa de Saúde da Família para busca de contactantes, orientação das famílias e do paciente.

São vinte pacientes em terapia anti-retroviral e tratamento de tuberculose simultâneo, dentre os quais sete assumidamente também usuários de drogas, que participaram desta pesquisa. Existem grupos de nutrição, aulas de informática, conserto de microcomputadores, dentre outras atividades, incentivando que os pacientes vinculem-se ao serviço não necessariamente em função de seu tratamento anti-retroviral ou efeitos colaterais, mas por outros projetos. Não há grupos específicos de adesão. 
Tabela 16. Pacientes do serviço SM1, segundo tipo de patologia. São Paulo, 2005.

\begin{tabular}{lllll}
\hline Indicadores & Aids & HIV & HIV + TB & Total \\
\hline Matriculados/geral & 263 & 297 & 48 & 608 \\
Em seguimento & 248 & 292 & 45 & 585 \\
Masculino & 129 & 166 & 37 & 332 \\
Feminino & 119 & 126 & 8 & 253 \\
Gestante & 3 & 6 & 0 & 9 \\
TARV & 164 & 54 & 20 & 238 \\
Abandono & 0 & 0 & 0 & 0 \\
Mud. Diagnóstico & 0 & 0 & 0 & 0 \\
Óbito & 14 & 3 & 3 & 20 \\
Transferência & 1 & 2 & 0 & 3 \\
Total & 941 & 946 & 161 & 2048 \\
\hline
\end{tabular}

Fonte: Prefeitura do Município de São Paulo, Área Temática de DST/aids, setor de Pesquisa, 2005. OBS: O serviço SM 1 não dispõe de Assistente Social em seu quadro de funcionários.

Em relação à tuberculose, no serviço SM1, todos os profissionais foram treinados para identificar os sintomas da tuberculose pulmonar, abordar o paciente e caso possível, solicitar exames, que são lidos sempre pelo médico.

Como resposta à questão 'frente ao paciente com aids, como faz para buscar tuberculose'?, os seguintes trechos (quodes) selecionados fundamentam a afirmação que este serviço tem, de fato, uma política específica para atendimento de tuberculose -a única dentre os serviços participantes deste estudo:

- Todo paciente que entra no ambulatório, todo. Todo paciente que entra no ambulatório ele faz vários exames, entre eles, raios- $X$ de tórax, entre eles, PPD. Todo mundo tem que fazer isso. Então, esse é o primeiro passo. Todo paciente que já está conosco, se a gente tem um paciente da pediatria, que tem a tuberculose, que o pediatra mesmo, já vai solicitar todos os exames para a família e essa família vai passar com o médico, com o clínico. Então, é uma forma de estarmos sempre ligados. Como o ambulatório é pequeno, tTodo mundo aqui, todos no ambulatório, não é só médico, pedir BK de escarro, pedir PPD, não é ato só médico. Pedir raios-X, não é um ato só médico (médico). 
- Essa prática começa aqui no ambulatório, acho que em 93 se eu não me engano. Em 93/94, que a gente tinha um boom aqui de tuberculose. Era um negócio assustador. Tuberculose era a primeira doença, entre aspas, de doença oportunista do ambulatório. Nessa época, treinamos todos. Do faxineiro ao médico para pensar em tuberculose o tempo todo. Então, se o cara está lá, se o faxineiro vir o paciente tossir várias vezes, certamente ele iria perguntar: "Há quanto tempo você está com essa tosse?" Ele iria dizer: "Fale com a enfermeira!" E a enfermeira pediria os exames dele. Com o intuito de a agilizarmos que o cara possa fazer o exame, senão ele terá que entrar no agendamento do médico. Nada melhor, do que pegar o cara aqui, mas a agenda dele com o médico é daqui a um mês. Nada melhor, do que pegar agora. Se a enfermeira está aqui, viu isso, ela pede BK de escarro, PPD para ele. O cara faz o exame, e no outro dia, o primeiro médico que estiver aqui, não necessariamente o médico dele, mas o primeiro médico que estivar aqui, vai olhar esses exames. Se ele estiver tuberculose, ou indício de tuberculose, vai começar a tratar e aí, vai ser encaminhado para o médico dele (médico).

- Se ele estiver se queixando, se ele tiver aquelas queixas clássicas, emagrecimento, febre vespertina, tosse e tal, será pedido o exame de tuberculose. Para qualquer pessoa daqui. Obviamente, estamos num ambulatório de aids, você terá outras tuberculoses que não pulmonar; tuberculose ganglionar e o médico que acabará...é obvio que o cara já está há 30 dias com febre, ele vai ver com quem ele tem consulta daqui há um mês, ele vai passar com alguém aqui. Alguém vai examiná-lo, alguém vai pedir os outros exames (enfermeira).

- Temos alguns caminhos a seguir. Pede-se exame de escarro para todos eles, pede-se PPD e segue clinicamente, alguns pacientes podem ter TB sem ter baciloscopia positiva e pode-se tratar esses pacientes baseado na evolução clínica dele, desde que ela especifique claramente que ele tem TB (enfermeira). 
- Para todo paciente se faz pedido de BK e PPD, é rotina, todo profissional deste serviço pede esse exame. No próprio questionário de avaliação do paciente existe uma cláusula que pergunta se ele entrou em contato com alguém com tuberculose, ou se ele está com tosse há mais de duas semanas. Se tiver algum quadro clínico que indique tuberculose, fazemos a pesquisa com os exames específicos (nutricionista)..

- Normalmente na entrevista do acolhimento já fazemos a pesquisa sintomática, então se ele tem tosse, a gente já faz a solicitação do BK, se não tem tosse a gente faz o PPD. É rotina de recepção de pacientes portadores fazer o PPD em todos os pacientes que são matriculados (médico).

O serviço SM1 tem todos os funcionários capacitados e treinados para observar e encaminhar os casos de tuberculose, o que é único. Cada profissional tem a responsabilidade de zelar pela percepção e encaminhamento dos pacientes em caso de percepção de tosse ou mesmo sudorese excessiva, dentre outros sintomas - e a leitura dos exames fica a cargo dos médicos.

\section{b) Serviço Municipal 2 - SM2 : Centro de Referência}

O serviço 2 é um Centro de Referência em DST e Aids da prefeitura de São Paulo, e segundo o 'site',

são unidades de prevenção e assistência que dão suporte aos serviços de controle das DST/AIDS. Realizam exames diagnósticos, tanto os de rotina como os de urgência (incluindo endoscopia, ultrassonografia e radiologia) e desenvolvem projetos e programas de orientação e prevenção de doenças sexualmente transmissíveis.

Este serviço apresenta uma taxa registrada de abandono de tratamento de aids de $35,1 \%$, considerada também pelos profissionais do serviço como alta. São 45 pacientes com co-infecção aids/tuberculose, 11 dos quais se identificaram como usuários de drogas e participaram do presente estudo. Já houve tentativas de formação de grupos de adesão em 2001, porém não houve continuidade.

Segundo relato da direção, o serviço apresentava suporte da UNAIDS para 
fornecimento de cesta-básica para os pacientes com tuberculose, porém este foi suspenso no início de 2005 pela prefeitura de São Paulo, segundo relato da profissional de saúde.

Há controvérsias quanto à eficácia do fornecimento de subsídios, tanto na fala dos profissionais de saúde quanto no discurso dos pacientes: por um lado, a importância de ter alimento para ingestão dos remédios. Por outro lado, num país de graves contradições sócio-econômicas e grande parte da população abaixo do nível de miséria, pode haver recidiva 'intencional' (o paciente não ingere os remédios, não toma as medidas profiláticas adequadas e permanece adoecido) para não perder o benefício.

Tabela 17. Pacientes do serviço SM2, segundo tipo de patologia. São Paulo, 2005.

\begin{tabular}{lllll}
\hline Indicadores & Aids & HIV & HIV + TB & Total \\
\hline Matriculados/geral & 1479 & 456 & 49 & 1984 \\
Em seguimento & 1035 & 279 & 47 & 1361 \\
Masculino & 564 & 123 & 34 & 721 \\
Feminino & 441 & 456 & 13 & 910 \\
Gestante & 6 & 5 & 0 & 11 \\
TARV & 948 & 82 & 45 & 1075 \\
Abandono & 218 & 143 & & 361 \\
Mud. Diagnóstico & 0 & 3 & & 3 \\
Óbito & 145 & 8 & & 153 \\
Transferência & 61 & 21 & & 82 \\
Total & 444 & 177 & & 621 \\
\hline
\end{tabular}

Fonte: Prefeitura do Município de São Paulo, Área Temática de DST/aids, setor de Pesquisa, 2005.

A rotina em relação à tuberculose é assim descrita: os pacientes que têm tuberculose com tratamento supervisionado vão ao hospital-dia pegar a sua medicação, que já está pronta, com a auxiliar de enfermagem. Há um "livro de ponto" para o paciente assinar assim que toma o remédio. Neste livro constam os nomes dos remédios que estão em uso. É uma sala que não é exclusiva para esse atendimento. Para os finais de semana, já são preparados os remédios p/ que o paciente tome em casa. Em seguida, dá-se o lanche, sendo que muitos deles não chegam a comer, ou porque não querem, ou porque acham ruim, e saem ainda em jejum.

Neste serviço, a proximidade com instituições de detenção - na época da realização da pesquisa, ainda existiam presídios no interior de delegacias de polícia - e Fundação para 
o Bem-Estar do Menor (FEBEM) modificam a rotina de atendimento: a entrada de pacientes algemados e com policiais aguardando na porta traz um stress adicional à equipe clínica e mesmo a outros pacientes.

Os médicos são exigentes quanto à pontualidade, ou seja, se o paciente se atrasa para a consulta, nem sempre é atendido,e justificam esse comportamento (que pelos pacientes é considerado "inflexível") pelo fato de terem mais de um emprego, e as distâncias na cidade de São Paulo muito grandes, bem como o tráfego ser bastante pesado.

\section{c) Serviço Municipal 3 - SM3 : Ambulatório de Especialidades}

O serviço aqui denominado SM3 é um Ambulatório de Especialidades, que de acordo com as informações obtidas no 'site' da prefeitura de São Paulo,

são unidades que prestam atendimento especializado em: cardiologia, neurologia, dermatologia, ortopedia geral, cirurgia geral, ginecologia, otorrinolaringologia, oftalmologia, pneumologia, fonoaudiologia, psiquiatria e serviço social. Alguns Ambulatórios de Especialidades contam ainda com outras especialidades como clínica de queimados, reumatologia, endocrinologia, urologia, infectologia (incluindo DST/Aids) e especialidades infantis.

A taxa de abandono ao tratamento de aids notificada (oficial) é de 3,9\%, muito inferior ao que foi constatado no presente estudo. Em relação à tuberculose, mantêm uma sala separada para os pacientes em tratamento, que é uma sala pequena, fechada, escura e úmida, segundo dados de observação e mapeamento - portanto, inadequada para atender casos de tuberculose.

$\mathrm{O}$ ambulatório tem grande número de pacientes matriculados e em tratamento, e apresenta como estratégia para melhoria da adesão a formação de grupos de atividade física,específicos para os pacientes em tratamento anti-retroviral que apresentam lipodistrofia como efeito colateral mais importante. 
Tabela 18. Pacientes do serviço SM3, segundo tipo de patologia. São Paulo, 2005.

\begin{tabular}{lcccc}
\hline Indicadores & Aids & HIV & HIV + TB & Total \\
\hline Matriculados/geral & 1157 & 440 & 11 & 1608 \\
Em seguimento & 598 & 204 & 11 & 813 \\
Masculino & 366 & 115 & 10 & 491 \\
Feminino & 232 & 89 & 1 & 322 \\
Gestante & 53 & 30 & 0 & 83 \\
TARV & 547 & 6 & 4 & 557 \\
Abandono & 128 & 131 & 0 & 259 \\
Mud. Diagnóstico & 0 & 0 & 0 & 0 \\
Óbito & 0 & 0 & 0 & 0 \\
Transferência & 204 & 87 & 0 & 291 \\
Total & 3285 & 1102 & 37 & 4427 \\
\hline
\end{tabular}

Fonte: Prefeitura do Município de São Paulo, Área Temática de DST/aids, setor de Pesquisa, 2005.

Há uma sala nos fundos do ambulatório próprio para o tratamento supervisionado. Os remédios já estão separados em potes plásticos para que o paciente chegue, e somente tenha que ingerir e em seguida, é dado o lanche.

Um dos pacientes entrevistados, morador de rua, após o término do tratamento supervisionado de tuberculose, segue o tratamento supervisionado para aids, devido à sua condição de ausência de moradia fixa, alimentação e rotina. O serviço fornece a alimentação para que o tratamento tenha eficácia, o que termina sendo um 'arranjo' sócioeconômico, pois o paciente tem alimento e medicamentos disponibilizados.

\section{d) Serviço Estadual - SE 4}

O Serviço SE 4 pertence ao Estado, e centraliza demandas de vários municípios que muitas vezes não têm condições para atender aos seus pacientes. Existe uma equipe, a nível ambulatorial, que trata especificamente da co-infecção aids/tuberculose. Segundo a assessoria de imprensa do serviço aqui denominado SE4, os atendimentos realizados são os seguintes:

Atendimentos ambulatoriais HIV/AIDS - 4000 pacientes;

Atendimentos ambulatoriais DST - 800/mês;

Pronto-atendimentos - 800/mês;

Atendimento domiciliar - 12/mês. 
Não foi possível obter informações pormenorizadas, como nos serviços da prefeitura, a respeito do número de pacientes em atendimento, pacientes co-infectados, etc. Esses dados também não estão disponibilizados no setor de Pesquisa da Secretaria Estadual de Saúde. Os dados obtidos na internet, no 'site' da Secretaria Estadual de Saúde de São Paulo, a respeito da estrutura deste serviço são os seguintes:

O serviço SE 4 é organizado em três gerências: prevenção, vigilância epidemiológica, assistência integral à saúde, apoio técnico, recursos humanos, gerência administrativa, e cada uma com pelo menos dois núcleos de atuação. Este modelo organizacional é considerado inédito na América Latina e no Brasil, e avaliado pelos profissionais como responsável pelos êxitos obtidos pelo serviço.

O serviço SE4 realiza encontros semanais para adesão, grupos para tratamento de lipodistrofia, orientados por psicólogas. São grupos chamados abertos, pois qualquer pessoa (mesmo não-portadora) pode participar e a freqüência não é obrigatória. Já existem há dez anos, quando - com o advento da TARV - a lipodistrofia surgiu como importante efeito colateral dificultando a adesão.

\subsubsection{Análise do atendimento de tuberculose nos serviços pesquisados:}

Os itens do roteiro utilizados para esta análise foram:

1. Como se dá a busca de pacientes com tuberculose nos serviços de DST/Aids;

1.1. Busca de contactantes;

1.2. Mecanismos para busca dos pacientes faltosos ou com ausência não-justificada.

2. O tratamento da tuberculose:

2.1. Os tipos de tratamento oferecido;

2.2. O tratamento para co-infecção aids/tb;

2.3. O acompanhamento dos pacientes com aids/tb em comparação ao pacientes com aids ou apenas soropositivos para HIV;

2.4. A vigilância epidemiológica da tuberculose no serviço de aids.

2.5. O papel da equipe multiprofissional no acompanhamento dos pacientes. 
A questão do roteiro semi-estruturado para profissionais de saúde, referente à tuberculose era "Quando vem um paciente com aids, como vocês fazem para buscar tuberculose?", e os resultados foram bastante diversos nos quatro serviços pesquisados.

O serviço SM1 tem treinamento para todos os funcionários e parceria com Programa de Saúde da Família, o que permite um acompanhamento mais minucioso dos pacientes co-infectados aids/tuberculose.

Nos outros serviços, SM2, SM3 e SE4, a identificação e diagnóstico da tuberculose são atribuições exclusivas dos médicos infectologistas, embora os não-médicos e médicos não-infectologistas eventualmente façam encaminhamento em função da queixa do paciente.

Os seguintes trechos fundamentam essa descrição:

- Aqui no CR são feitos pedidos os exames quando o paciente chega de uma forma em geral e quando ele está meio sintomático, ou seja, febre persistente, tosse persistente, mal-estar que pode ser característico da tuberculose e são pedidos os exames. Geralmente, se não é na consulta do paciente, que ele está na situação clínica, quando ele tem esse mal-estar persistente, ele vem fora de consulta no pronto-atendimento (enfermeira).

- Normalmente na admissão do paciente é investigado se ele tem algum sintoma respiratório, alguma febre a esclarecer, é feito já na admissão o exame PPD, que é um exame importante para saber se tem tuberculose e se tiver sintomática respiratória fazemos uma investigação mais profunda: raios- $X$ escarro e outros exames necessários Sempre buscamos identificar a tuberculose no paciente.[E se ele já for um paciente seu?] Já costuma fazer parte da minha análise perguntar sobre tosse, febre, sudorese ou perda de peso, isso é normal durante as consultas e qualquer indício, faço toda a investigação novamente (médico).

- Procurar pelos sintomas, se o paciente tem tosse ou se queixa de algo peço exame de escarro para investigar (médico infectologista).

- Ocorre uma série de procedimentos. Se for um paciente HIV assintomático, verifica-se os dados, se tem tosse, febre, emagrecimento, solicita-se raio x. Se o paciente for sintomático pede-se o escarro (médico infectologista).. 
- Como aqui é um local com uma equipe multidisciplinar, nessa parte, se eu suspeito de TB eu encaminho ao infectologista (psicóloga).

- Quem cuida mais desse tipo de serviço são os infectos, mas basicamente é o quadro clinico... Queixa de tosse...(psicóloga).

- Olha, normalmente quando tem ele já vem com raios-X, já vem encaminhado do Sabóia (Hospital) e já sai do acolhimento com consulta a pneumo, com consulta com o infecto, já tudo esquematizado... [Já vem encaminhado de outro serviço?].Normalmente sim, e se ele vem... Se eu dou o resultado positivo, por exemplo, aí eu colho se ele tem febre todos os dias, tosse progressiva e já encaminho para o infecto e o infecto avalia tudo clinicamente e aí se manifestar depois o infecto manda para o pneumologista (psicóloga).

- Geralmente aqui no nosso ambulatório a orientação que temos é de investigar na pré consulta se há pacientes sintomáticos, pacientes que apresentam tosse, febre, mas paralelamente a isso a gente recebe encaminhamento dos médicos, os infectologistas encaminham para o ambulatório de tratamento supervisionado os pacientes que eles querem que sejam acompanhados especificamente da tuberculose. A maior parte dos pacientes que vêm para o ambulatório, vem encaminhados por esses infectologistas (enfermeira).

- A gente faz abordagem em relação à tosse... mais tosse, o estado geral. Os pacientes de aids eles já fazem de protocolo uma pesquisa de tuberculose, fazem $P P D$, então, vamos seguindo esse caminho. Se tem tosse, expectoração, a gente já pede exame, colhe na olha e a maioria deles fazem PPD e teste de raios- $X$ (médico infectologista).

\section{A) Como se dá a busca de pacientes com tuberculose nos serviços de DST/Aids}

Em síntese, os serviços de DST/Aids dispõem de mecanismos diversos para busca da tuberculose, desde a capacitação e orientação de todos os funcionários e equipe (SM1) até a responsabilização do médico infectologista pelo diagnóstico (SM 3 e SE 4).

Todos os pacientes que tiveram diagnóstico de tuberculose em serviços de saúde nãoespecializados (hospitais gerais, postos de saúde, etc.) foram testados para HIV e tiveram o resultado revelado no local de realização do teste. A revelação diagnóstica nem sempre foi 
considerada a mais adequada, porém o fluxo diagnóstico de tuberculose - teste para HIV foi realizado com todos pacientes aqui selecionados.

\section{A.1) Busca ativa de contactantes}

Os resultados obtidos com a pergunta "Fale um pouco sobre os pacientes com tuberculose neste serviço” e a sondagem "como se faz a busca de contactantes (e pacientefonte)?” permitiram avaliar que apenas os serviços SM1 e SM2 têm um sistema implementado de busca ativa, em parceria com Programa Saúde da Família.

É freqüente o paciente estar em tratamento em dois serviços, sem que essa informação seja compartilhada. Os profissionais não-médicos têm atuação mais intensa nessa etapa do processo do que os médicos, o que reforça a importância do trabalho da equipe multidisciplinar para que as diversas faces de um problema de saúde pública sejam contempladas.

CAPUANO (2003) refere-se à situação epidemiológica no Município de São Paulo, que contribui com metade dos casos notificados no Estado e com cerca de oito por cento do total de casos da doença no país - como principal razão para busca ativa de casos. Em seu estudo, o autor trabalha com uma amostra de pacientes alcoolistas e usuários de drogas ilícitas, de um serviço de farmacodependência em São Paulo, para a busca de casos de tuberculose. Conclui que estariam sendo atendidos em outros serviços de saúde, principalmente hospitais.

Pode-se inferir que os pacientes com tuberculose e usuários de drogas, tendo ou não sorologia HIV+, não estão sendo monitorados pelo sistema de saúde, que por sua vez não dispõe de mecanismos para avaliar a seqüência destes pacientes na rede de referência e contra-referência.

O controle de comunicantes de tuberculose também não está sendo realizado nos serviços de DST/Aids, com perda de dados e informações. Em pesquisa datada de 1998, ALVES estuda a avaliação sistemática de comunicantes de pacientes bacilíferos e a qualidade das informações contidas nos prontuários ${ }^{1}$, verificando se houve orientações aos casos-índice e seus comunicantes a respeito da doença.

No estudo, a autora comparou as normas brasileiras e britânicas para o controle da tuberculose. Houve significativa ausência de informações sobre características sócio- 
econômicas do paciente, como tipo de domicílio (90,6\%), renda (95,5\%), escolaridade (96,9\%) e número de pessoas que dormiam no mesmo cômodo (82,4\%). Como resultados, a presença ou ausência de tosse não foi anotada em 20,7\% dos prontuários; não houve cumprimento das normas brasileiras, nem uniformidade de condutas. A qualidade do preenchimento dos prontuários foi insatisfatória e apenas parte dos casos e comunicantes receberam orientações sobre a doença, conclui.

Dos serviços de DST/Aids pesquisados, só existe um trabalho educativo implementado e sistematizado acerca da prevenção e profilaxia da tuberculose, no SM1. Em geral, não há registro acurado dos dados sócio-demográficos dos doentes com tuberculose, tampouco registro de seus tratamentos anteriores.

Os seguintes trechos foram selecionados para fundamentar a reflexão sobre o tema:

- Por exemplo, a tuberculose. Quando o paciente tem algum problema, falta, ou a gente recebe alguma ligação que ele fazia tratamento num outro serviço, porque às vezes até descobrimos que o paciente faz tratamento aqui e em outro lugar também, então a gente faz uma visita a domicilio, reorienta onde ele deve seguir com o tratamento, faz atendimento a familiares $e$ também somos referência para teste tuberculínico na região toda, para todos os contactantes de tuberculose.

- Os exames necessários para o diagnóstico. Escarro e raios-X do tórax, uma vez diagnosticado conscientizar o paciente da necessidade de tratar $e$ também informá-lo com relação a possibilidade dos contactantes domiciliares, com relação as pessoas que convivem com o paciente especificamente crianças que são mais sensíveis e que deverão ser levadas ao pediatra estando ou não com os sintomas, tomar (ou verificar se já tomou) a vacina BCG e os demais contactantes caso apresentem os sintomas recorrer a um serviço de saúde para investigação.

- Não, quando a gente faz o acolhimento, quando é a $1^{a}$ vez que o paciente chega aqui, já instituímos a busca ativa, que é a busca situacional, então temos um carimbo - que foi a forma mais prática de estarmos fazendo no 
acolhimento, para todas as pessoas que entram na unidade. Então, se tosse, já pedimos o exame do escarro, e como já faço parte do programa de tuberculose aqui na ------, ele já é feito com cultura também, então já temos a análise dos exames. Se ele tosse já fazemos esse pedido, se não tosse só fazemos o HIV, se ele for + no HIV fica fazendo parte da unidade, se não e ele for tuberculoso daí encaminhamos para a unidade próxima de sua casa e ele tem que continuar tratando a tuberculose, que aí é tuberculose pura.

- Não, nós montamos. Dentro do programa tem a busca ativa, que é perguntar para todas as pessoas que passam pela unidade se ela tem tosse, porque aqui é uma unidade aberta - atende raios- $X$, ultra-som, as vezes a pessoa só vem na farmácia... Então para não perguntar para todo mundo, perguntamos somente para quem vem fazer o exame, até porque temos uma idéia de que se pessoa vem com Raios-X, ela já vem de outra unidade, e essa outra unidade teria de estar perguntando se o paciente tosse ou não, se tem algum problema de tuberculose. E nas outras unidades tem também o PSF que também faz esse trabalho. Então acabamos centrando naquela ficha de acolhimento a pergunta se tosse ou não.

- Quem dá o resultado do exame somos nós (quem fez o acolhimento) se quem fez o acolhimento não estiver aqui, a pessoa que está atendendo o paciente é quem comunica o resultado, para que o usuário não fique esperando. O importante de tudo isso é ter esse movimento das perguntas pelo menos nesse programa de tuberculose, pois como a B.e F. são os bairros com maior índice de tuberculose em São Paulo, então foi instituído através de um órgão (me esqueci como se chama) que atende exclusivamente tuberculose, eles fazem supervisão de tuberculose em nossa unidade (inclusive amanhã teremos uma) e além de estar vindo pra a unidade o programa com alguns incentivos como: o BK, juntamente com a cultura, eles colocaram alguns ventiladores na unidade, janelas próximo à escada, tudo isso é para estarmos atendendo realmente pessoas com 
tuberculose que habitam na região e estar diminuindo o índice. A idéia é estar minimizando a quantidade de tuberculosos encontrados. É uma região carente, populosa isso torna a concentração de bacilos muito grande.

A baciloscopia direta do escarro constitui-se no exame prioritário nos casos suspeitos de tuberculose, segundo o Programa de Controle da Tuberculose em nível nacional (HIJJAR, 1994). A cultura do material está indicada naqueles casos onde existe a suspeita clínica e radiológica de tuberculose mas que apresentam exames de baciloscopia direta repetidamente negativos. Porém, esta baciloscopia não é feita, nem solicitada, para os comunicantes.

- Uma outra coisa que surgiu, como tratamos dos pacientes aqui e quando estão com tuberculose já orientamos a família também, é da pessoa estar ligando no posto de saúde, por exemplo: a pessoa chegou agora foi colher o escarro e deu positivo, se ele é HIV já fica aqui como paciente nosso e se ele não é HIV, mas tem tuberculose fazemos uma cartinha e entramos em contato com o posto, existe a ficha de notificação e nela consta o número de pessoas da família e essas pessoas entram como comunicantes e fazem o exame no posto mais próximo.Então, se ele é positivo saí daqui como tendo tuberculose, nós ligamos para a unidade e esta vai até a casa da pessoa constatar e 'fechar' esse paciente para que este não abandone o tratamento. Eu particularmente não peguei nenhuma pessoa que seja tuberculose pura para fazer esse encaminhamento. Comecei a participar do programa a partir de novembro (2004) e estou tentando organizar todo esse fluxo, fechálo.

Em relação à busca ativa de contactantes, embora em dois dos quatro serviços os profissionais de saúde relatem programas e atuações, na triangulação com as entrevistas dos pacientes, nem sempre são relatadas intervenções formais nas famílias, orientações para hábitos de higiene ou mesmo informações básicas sobre prevenção, infecção e contaminação. 
Alguns pacientes relatam que deixaram de ter relações sexuais por terem medo de infectar seus parceiros com beijo e secreções. Os trechos das entrevistas com pacientes que fundamentam essa idéia são os seguintes:

- Lá em casa é assim, como eu tenho problema nas vistas, não consigo tomar o remédio direito....meus sobrinhos me ajudam, mas não estão lá todo dia...aí eu venho aqui e tomo o remédio de manhã

- Tenho medo de beijar, de abraçar, e passar tuberculose pra ela

- Trazia todo mês, toda vez no máximo de dois em dois meses, pra fazer o teste......porque eu tenho tuberculose, sabe, então não sei se ela pega ou não pega....até hoje não pego, graças a Deus

- Sei não [como pegou tuberculose, se passa pra alguém]... larguei o tratamento, tava melhor, depois caí no abuso, assim, entrei com tudo na droga de novo, abusei, aí fiquei tão mal que fiquei três meses internado tomando remédio na veia....

\section{A.2) Busca dos pacientes que faltam ou abandonam}

Ainda como resposta à pergunta Fale sobre os pacientes com tuberculose neste serviço, foi possível compreender como os serviços estão trabalhando com a questão das faltas não-justificadas, das ausências consecutivas e da ausência que caracteriza o abandono.

A referência do MINISTÉRIO DA SAÚDE (2002b) para alta por abandono de tratamento será dada ao doente que deixou de comparecer à unidade de saúde, por mais de 30 dias consecutivos, após a data aprazada para seu retorno.

Nos serviços, não há padronização para as ações de identificação de pacientes em abandono ou ainda busca dos faltosos. Um dos argumentos é que não há clareza quanto à pertinência de se procurar o paciente em casa sem saber ao certo se ele assim o deseja.

Os trechos que apóiam essa idéia são:

- Já fui buscar paciente em casa, paciente que faltou demais.....tava mal. Mas já passei aperto, já jogaram lixo em mim.... não se sabe o que o paciente quer, afinal. 
- A gente passa telegrama, uma, duas, três vezes. Não pode passar mais porque o serviço não paga, e não vou tirar do bolso. Se ele não vier, paciência, fazer o quê?

- Aqui (serviço SE 4) a gente procura cuidar de perto, se o paciente faltou uma, duas, três vezes, mas remarcou, explicou e tal, tudo bem, a gente deixa pegar medicação e tudo. Mas nem todos autorizam a gente a ir atrás, telefonar, tudo... às vezes a família nem desconfia de nada, aí toca o telefone, fala que é do serviço de aids, pronto....

O serviço 4 tem, no prontuário do paciente, um item específico em que ele autoriza ou não que se faça contato com ele em caso de falta ou abandono, e quais as formas. Se pode ser por telegrama, telefonema ou contato direto, visitas. Neste serviço, não há parceria com PSF ou outros serviços em que a comunidade esteja envolvida.

- Quando o paciente falta, nós ligamos para ele, e se for necessário eu vou até sua casa para saber o que está acontecendo, tento ver... Tivemos até um caso de uma paciente que abandonou o tratamento, eu fui até a casa dela fazer visita e ela estava num período que não queria saber mesmo do tratamento, estava muito mal e aí deixamos a seu critério, até porque ela estava usando droga, mas quando estava muito mal mesmo retornou ao serviço, começou o tratamento médico e a participar do grupo de redução de danos, e por enquanto ela está indo bem.

Frente a essa gravíssima situação, em que os serviços de DST/Aids e o sistema de saúde não têm condições para monitorar os pacientes em seus tratamentos para tuberculose, é perfeito o cenário para aumento da incidência de tuberculose multidrogarresistente e da adesão. 


\section{A.3) O tratamento da tuberculose}

As perguntas e respectivas sondagens do roteiro para profissionais de saúde referentes a tratamento de tuberculose foram as seguintes:

Pergunta: Como você descobre se o paciente com HIV tem tuberculose?

Sondagem: Como é feito o tratamento destes pacientes?

Pergunta: Gostaria que você me falasse um pouco dos pacientes com tuberculose aqui no serviço?

Sondagem: Comente sobre os tratamentos oferecidos no serviço para estes pacientes com aids e tuberculose.

Nas respostas os entrevistados falaram sobre o tratamento da tuberculose que haviam realizado. Por definição institucional, a tuberculose é tratada nestes serviços apenas se em associação com HIV: o paciente com tuberculose sem ser como co-infecção, é encaminhado ao posto de saúde próximo da residência.

Isto demonstra que o serviço de referência em saúde, que teoricamente deveria tratar de todas as doenças de maneira integrada e dentro das normas, apenas está encaminhando o paciente com tuberculose e o que também é grave não existe um mecanismo para certificação deste encaminhamento ter sido bem sucedido.

Os seguintes trechos foram utilizados para subsidiar as reflexões sobre como os serviços de DST/Aids vêem a questão do tratamento da tuberculose:

- Só tuberculose a unidade não faz o tratamento, só faz se a tuberculose for associada ao HIV. Mas hoje em dia eu não cheguei a participar de nenhuma reunião, mas eu sei que o pessoal tem tomado umas medidas bem centradas, as enfermeiras podem até te falar melhor dessa rotina, mas eles estão fazendo uma campanha / supervisão bem legal, um negócio bem organizado com a tuberculose, foram em treinamento $e$ coisas do gênero. Eu fico na parte da medicação, mas sei que o pessoal tem amarrado bem esse assunto. Sei que a unidade não faz só a tuberculose pura.

- Eu só atendo HIV+, tuberculose pura não, porque o nosso posto não é de tuberculose, não que eu não saiba atender, mas nosso posto não atende a tuberculose pura, se paciente tiver a tuberculose sem o HIV ele 
é encaminhado para uma unidade básica, porque senão enlouqueceríamos...

- Nnão atendemos tuberculose pura.

- Eu não faço (atendimento a pacientes que tenham só tuberculose), porque como eu não faço essa parte de assistência, e aqui é só a primeira parte de testagem, o que acontece às vezes é o caminho inverso: a pessoa vem com, por exemplo, ela vem com queixa, já aconteceu uma vez uma paciente que está aqui com uma colega, ela veio fazer a testagem do HIV e no fim a colega falou "olha eu estou com muita tosse, estou mal” e começou a descrever alguns sintomas que na hora eu pedi para ela ser encaixada com uma pneumo, porque achei que poderia ser tuberculose. Então a gente tem escuta para HIV, mas a gente não deixa de ter uma escuta também para outros sinais, de repente a gente encaixa em consulta.

- A TB no ambulatório é onde atende a maior parte, a maior concentração do paciente com TB é lá. Porque lá tem a TB supervisionada. Aqui no HD já teve alguns anos atrás. Então, a gente pesava o paciente, conferia as drogas. Toda semana fazíamos a avaliação do paciente. Só que, uma vez que tem uma equipe lá no ambulatório, então, a equipe está mais voltada para o ambulatório. A gente já teve esse trabalho aqui com tuberculose.

\section{A.4) Tratamento para co-infecção aids/tuberculose}

Os profissionais de saúde entrevistados utilizam as informações do Consenso 2005 (MINISTÉRIO DA SAÚDE, 2005b) para tratamento da co-infecção aids/tuberculose. Os médicos infectologistas têm clareza da necessidade de se avaliar os casos individualmente, com prioridade para o tratamento da tuberculose. Os trechos que fundamentam esse tema são:

- O tratamento em caso de co-infecção AIDS/TB precisa ser avaliado caso a caso, e segundo o Consenso (MINISTÉRIO DA SAÚDE, 2005b), deve ser priorizado o tratamento da tuberculose. 
- Depende, é uma conduta personalizada, se o paciente está bem de HIV trata-se a tuberculose, dependendo trata-se os dois juntos. [Não existe contra- indicação para isso?]

- Preferencialmente trata-se $1^{\circ}$ a tuberculose, o paciente que está ruim e dá entrada no hospital verificamos qual é a doença que está causando danos, depois que ele começa a aceitar remédios introduzimos o ARV

- Especificamente esse centro é para HIV co-infectados nossos pacientes muitos sim vêm de hospitais já tratados com alta dos esquemas alternativos para tuberculose (que é resistência tuberculose).

- O paciente com tuberculose e AIDS, focamos fundamentalmente estar tratando a tuberculose e em algum momento ele estar tomando os ARV. Usando um exemplo simples, o paciente com tuberculose AIDS entre os $A R V$ e a medicação para tuberculose você favorece primordialmente o tratamento da tuberculose.

- Os medicamentos são esquemas de tuberculose esquema 01 e 02 certo que Isoniazida, Pirazinamida é o tratamento usual; o período para quem tem tuberculose co-infecção HIV é estendido diferente de uma pessoa que não é HIV.

- Eles fazem todo o tratamento normal que os demais pacientes fazem, eles vêm mais abalados por causa do emagrecimento que acompanha, vêm mais assustados, eu acho. Geralmente contam a história do emagrecimento que não sabiam da tuberculose e que descobrem que tem o HIV também e daí é outra cacetada em cima, e quando não tem ficam na expectativa por achar que vai ter o HIV junto. Mas os que têm TB e HIV chegam aqui mais debilitados tanto físico como emocionalmente. Aí a gente vai orientando, faz grupos, atendimento individual, alimentação, medicação, passa para a enfermagem, passa com todo mundo para se fortalecer. 
Os médicos não-infectologistas preferem que a avaliação final seja feita pelo infectologista, assim como o tratamento. Mas têm a idéia do que é referenciado no Consenso. Os trechos que fundamentam essa idéia são:

- A gente atende, sim, mas encaminha para o infecto, que sabe o que pode, o que não pode, como faz....

- Pergunte ao médico infectologista, é ele quem trata dessas coisas.

- Ah, eu pessoalmente detesto atender tuberculose, quando chega e eu vejo que tem, já peço pra J. atender, porque não gosto....ela é infectologista, atende todos.

Se os profissionais de saúde forem melhor capacitados a dar suporte ao paciente que tem aids e tuberculose, para melhor orientação na busca ativa de contactantes, para os pacientes, seus familiares e as pessoas com quem convivem, pode haver grande melhoria no atendimento à tuberculose e controle da epidemia.

\section{B) Acompanhamento dos pacientes com aids/tuberculose em comparação ao pacientes com aids ou apenas soropositivos para HIV}

Para avaliar este item, foram analisadas as respostas à questão

São marcadas consultas distintas para o paciente com HIV e tuberculose ou tudo é feito na mesma consulta?

Da análise ficou demonstrado que o acompanhamento do paciente co-infectado aids/tuberculose é mais minucioso, com maior número de consultas em menor prazo,do que o acompanhamento para os pacientes não-coinfectados. A questão teve como respostas:

- Uma única consulta, na realidade ele vem com mais freqüência, pois o paciente só HIV vem a cada dois meses (o que está estável), já o que tem também a tuberculose é obrigatório que venha uma vez por mês. Todos os casos que estou acompanhando vejo mensalmente, se o paciente não estiver bem eu acabo vendo com mais freqüência.

- Inicia-se com o esquema tradicional (esquema 01), os pacientes com aids são diferentes do pacientes com tuberculose, esse programa é só de tuberculose. O paciente com HIV não tem resistência... 
- É. Os casos mais complicados são acompanhados mais de perto, mas isso não é feito apenas pela farmácia que fornece medicamento, mas pelo corpo clínico e enfermagem.

Neste caso, fica explícito que os serviços de DST/Aids pesquisados tentam monitorar, de modo mais próximo, o paciente co-infectado. Porém, não havendo mecanismos de busca dos faltosos, os profissionais não têm como interferir, na prática, na questão da freqüência, nas estratégias de busca, e o sistema continua falho apesar do esforço dos profissionais.

\section{C) Vigilância epidemiológica da tuberculose no serviço de aids}

Os dados sócio-demográficos dos pacientes com co-infecção aids/tuberculose não estão sendo coletados de modo a garantir uma vigilância epidemiológica fidedigna. As respostas à questão "Fale um pouco mais sobre os pacientes com tuberculose neste serviço" trazem à tona a dificuldade em se sistematizar os dados referentes à tuberculose, seja a doença atual ou sejam as doenças anteriores. Os trechos são os seguintes:

- Não temos nenhum levantamento... Nós temos um levantamento da forma clínica da TB, mas não temos um levantamento por sexo ou idade, por exemplo, temos todas as fichas que esse tratamento de TB com a participação da enfermagem vem sendo feito desde o ano 2000. Era feito por outra enfermeira, ela saiu e eu fiquei trabalhando aqui junto com outros colegas e a gente tem uma ficha específica que a gente acompanha.

- Toda vez que o paciente vem, registramos nessa ficha vários dados da doença dele, mas ainda não fizemos um levantamento de características pessoais como idade, sexo, tem por forma clinica, mas pelo que eu observo a maioria é da faixa etária dos 20 aos 49 anos, sexo masculino, estado civil casado para a maioria das mulheres e homens, a maioria solteiro...

- Deveria ter no prontuário do paciente, tudo que já aconteceu de tuberculose na vida dele... mas não tem. Nem o paciente sabe, nem o médico que está cuidando dele. Às vezes a gente consegue, pela 
informação dele, saber que já teve doença. Mas remédio, nome, essas coisas... acho que as informações estão se perdendo....

O estudo de ALVES (1998) refere-se à dificuldade de organização dos prontuários nos serviços de referência em saúde. Os registros precários, a falta de informações importantes para o acompanhamento da história natural da doença, e a falta de mecanismos institucionais para regulação destas falhas, tudo isso contribui para um cenário de duplicidade e/ou falta de informações, reduzindo as possibilidades concretas para uma vigilância efetiva das co-infecções.

Em 1995, foi proposta uma Ficha de Notificação de Casos (ARANTES, 1972) para ampliar o processo de monitorização das ações antituberculose na Grande São Paulo, com informações consideradas mínimas para o cálculo dos indicadores. Num segundo momento, foi definida uma sistemática de intercâmbio de informações entre o nível de coordenação e o nível de execução, com base nas experiências do Japão e do Rio Grande do Sul. Aderiram ao Sistema 141 unidades de saúde da Grande São Paulo.

TEJOS (2002) aponta para a discrepância entre os dados de tuberculose estimados pela OMS no Brasil em 1998 (129 mil) e os notificados ao Ministério da Saúde (85mil). As hipóteses para a diferença são a subnotificação, a baixa descoberta de casos ou ainda, problemas técnico-administrativos nos três níveis do Sistema de Vigilância Epidemiológica (SVE) local, regional e central.

Há falta de mecanismos de controle dos pacientes e seus respectivos tratamentos, da notificação e do registro, nos serviços estudados em São Paulo, necessitando intervenção efetiva. Mesmo com a formulação da Ficha de Notificação de Casos (FN) em 1995, no ano de 2000 o problema da duplicidade das informações e lacunas permanecia; e em 2005, ampliou-se de modo significativo para os serviços de DST/Aids.

No presente estudo, os pacientes com tuberculose (com ou sem HIV) relatam que não quererem ser atendidos em serviços próximos de suas casas por conta do preconceito e do temor em serem descobertos pelos vizinhos e conhecidos. Os trechos das entrevistas com pacientes que subsidiam esse argumento são:

- $\quad$ Não vou não, mesmo que seja ali do lado, não quero que ninguém me veja ali. 
- Sabe como é o preconceito... prefiro pegar condução, com tuberculose eu tenho direito ao bilhete.

- $\quad$ Não, não, já venho aqui e faço tudo....venho todo dia, tomo remédio....ou pego o remédio e tomo lá em casa....mas não vou lá, não, eles ficam comentando, é vizinho, é parente...

Os serviços pesquisados poderiam beneficiar-se com aprimoramento técnicocientífico nas ações de aconselhamento, orientações para casos de tuberculose e vigilância epidemiológica compartilhada com o Programa de Tuberculose.

\subsubsection{Tuberculose multidrogarresistente - TB/MDR - Conhecimentos dos profissionais de saúde}

A pergunta acerca da tuberculose multidrogarresistente, para os profissionais de saúde médicos infectologistas, médicos não-infectologistas e não-médicos, foi direta e simples: "O que você entende por tuberculose MDR?". Em alguns casos, o tema foi resposta à pergunta "Gostaria que você me falasse um pouco dos pacientes com tuberculose que você atende aqui no serviço”.

De modo geral, os médicos infectologistas têm o conceito correto e completo sobre TB/MDR, de acordo com as diretrizes do Ministério da Saúde; porém, os médicos nãoinfectologistas e os profissionais não-médicos apenas descrevem o óbvio referente ao nome, sem conhecimento técnico específico.

\section{A) Conhecimentos sobre TB MDR por médicos infectologistas}

Em relação ao conhecimento técnico-científico, os médicos infectologistas apresentaram o conceito correto sobre TB/MDR, e explicitaram necessidade de aumento de atenção a estes pacientes, em especial para evitar que precisem de terapias de resgate.

- Isso é um inferno. Isso é um inferno porque você terá que penar muito para tratar. Graças a Deus, eu não fico com esses pacientes. Eles são encaminhados para o Centro de Referência de Tuberculose, onde o pessoal 
terá muito mais condições de tratar esse paciente. Eles têm muito mais mão para tratar esse tipo de coisa do que eu. É um paciente que vai penar muito mais para tratar. Temos que ficar muito mais de olho. Porque antigamente achávamos que tuberculose multidrogarresistente normalmente, esses pacientes infectavam pouco.

- No caso, eu o encaminho. Não fico com ele, mas eu tenho que ficar mais esperto com a família dele, os comunicantes. Tem que ficar mais de olho. Quando o paciente sai do tratamento 1 de tuberculose, já começamos a ficar de cabelo branco. É uma situação que você já começa a ficar com medo, porque se o paciente responde bem no esquema 1, que ótimo. Seis meses e está resolvido o seu problema, se não responde bem a isso, você já começa a ficar preocupado. Se ele não responde a nenhum desses, esquema 1, esquema 2, esquema de resgate, e você faz cultura e dados de resistência, ou seja, vai passar para esquema que ninguém sabe se vai funcionar.

- Não é uma cobaia, porque tem os protocolos, mas você sabe que vai penar com aquele cara e perder hoje paciente por tuberculose é triste.

- Uma situação semelhante ao que acabamos de falar em relação ao HIV e os $A R V$ para a tuberculose. É aquela que não responde às drogas tradicionais para o tratamento, isso ocorre novamente pelo fator adesão, quanto maior o uso irregular do tratamento e necessidade de re-tratamento do paciente maior a chance de ele desenvolver, os bacilos que ele tem desenvolvem resistência aos medicamentos, exigindo um tratamento muito mais complexo, muito mais caro, mais efeitos colaterais, mais prolongado e não tão eficaz quanto o tratamento tradicional e um problema hoje é que uma pessoa pode se contaminar com um bacilo multirresistente sem nunca ter tido tuberculose antes.

- Pelo conceito do Ministério da Saúde é a TB com resistência a duas ou mais drogas do esquema 1.

- Paciente que tem resistência a mais de duas drogas no esquema 1 para tuberculose. O que leva à resistência são duas coisas, ou ele pode pegar 
uma bactéria já multirresistente, ou fazer o tratamento de forma irregular, que leva a uma resistência intrínseca.

Os médicos infectologistas têm um correto conhecimento da TB MDR, porém não avançam na análise em relação à profilaxia, às formas clínicas e técnicas para ser prevenir as recaídas e a própria resistência ao medicamento.

\section{B) Conhecimentos sobre TB MDR por médicos não-infectologistas}

Frente à mesma questão, “o que você entende por TB/ $M D R$ ”, os médicos nãoinfectologistas têm poucas e simplificadas explicações, afirmando que têm dificuldades na compreensão e encaminhamento desses pacientes. Atribuem o desenvolvimento da TB/ MDR ao abandono do tratamento como causa única e direta. Mencionam os "esquemas" sem discriminar quais seriam as drogas componentes, tampouco os motivos para substituições e trocas de esquemas.

Os trechos selecionados foram:

- Não sei.

- Com multi resistente caí muito a chance de cura.

- Aquela tuberculose que não responde mais àquele tratamento inicial, em que usamos três drogas e que os pacientes respondem muito bem, encontramos casos de TB multirresistente em pacientes que não concluíram tratamentos anteriores.

- Essa é complicada... Graças a Deus, não tive nenhum caso desses aqui, mas é necessário usar ou tentar esquemas super alternativos para tratá-la. Isso acontece com pacientes que abandonam muitas vezes o tratamento, pois no geral o bacilo é super sensível ao esquema de medicamento simples, mas quando a pessoa abandona muitas vezes o tratamento ele se torna resistente e aí necessário a troca constante de drogas, fazendo um esquema super alternativo para tratar a doença... Isso é muito difícil!

- Existe o “esquema 1" (esquema comum), o “esquema 1R” (esquema reforçado), depois existe um esquema com uma droga chamada Estreptomicina, usada quando o paciente desenvolve uma intolerância às 
drogas básicas de tratamento. Então é necessária a troca em alguns casos, pois o paciente desenvolve hepatite por causa da droga. Mas se ele for multirresistente existe o " $4^{\circ}$ tipo de esquema" em que se juntam alguns antibióticos (não me recordo os nomes). Ainda não tive nenhum caso de multi resistente.

- Paciente começa a tomar o esquema 1 abandona (vai e volta) várias vezes o tratamento, daí quando se vai fazer a cultura dá resistência a quase todas as drogas e falamos que a tuberculose se tornou multi resistente. Às vezes tentamos voltar ao esquema inicial, mas na maioria das vezes fico frustrada porque o paciente abandona o tratamento novamente (como no caso da paciente que mencionei).

Os médicos não-infectologistas têm um conhecimento que pode ser considerado superficial da questão da TB/MDR, também pautado na figura do paciente, como se pode observar nos trechos "começa a tomar e abandona", "abandona novamente", sem questionamentos sobre o papel do serviço na adesão, a importância do envolvimento da família e/ou da comunidade.

\section{C) Conhecimentos sobre TB MDR por profissionais não-médicos}

Os profissionais não-médicos entrevistados apresentaram explicações incorretas ou incompletas a respeito da TB MDR, com ênfase ao significado do termo 'multi', 'droga' 'resistente'. Atribuem o desenvolvimento de resistência ao abandono do tratamento e encaminham a dúvida sempre para que o médico responda. Têm dúvidas sobre o que seria resistência, qual a diferença do tratamento com comprimidos e o tratamento com antibiótico injetável, porém não admitem esse fato. Trouxeram o conceito de "paciente multidrogarresistente".

- Também é a mesma coisa (sem explicar nada antes).

- Especificamente eu não sei te responder, mas acho que é uma tuberculose resistente a várias drogas. 
- Bom, você se informa com o médico e depois me fala, mas deve ser isso, o paciente que já tomou todas as drogas e está resistente a tudo.

- Exatamente isso que te falei, se dá todo tipo de medicamento disponível para tuberculose e a pessoa não responde a nenhum esquema.

- Esse pode ser um termo novo...

- Porque às vezes até sabemos o caso mais desconhecemos o nome científico...

- Quando a pessoa inicia esse tratamento padrão, depois abandona. Depois chega uma hora que o remédio não faz mais efeito e tem que ser feita outra abordagem de tratamento...

- Correto, quando ocorre a falência dos esquemas padrões deve-se adotar esse procedimento.

- Imagino que deva ser a tuberculose que já está resistente a qualquer droga. Será que nesse caso existe cura, tem solução....? Bom, acho melhor você perguntar isso ao médico, não sei te responder, mas imagino que seja isso.

- Fica, ou melhor, já está (resistente), por isso é que ela já tomou um monte de coisas ou às vezes é o seu organismo que não está aceitando, ela está intolerante então é necessário fazer um esquema alternativo com esse outro medicamento (que não tem). Temos casos bem complicados, acredito que os injetáveis sejam bem difíceis também, já imaginou todo dia ter que tomar uma injeção? Mas esse já é o último estágio, o básico são dois meses, se o paciente segue as instruções direito já pára de tomar a pirazinamida e só toma Rifampicina, daí é tranqüilo, em 06 meses no mínimo tem que fazer o tratamento. Mas têm que ser rigoroso e tomar a medicação corretamente todos os dias (02 em jejum e 04 depois do café da manhã).

- Isso, o que iniciou o tratamento hoje, por exemplo, agora os casos que começam a complicar já vão para a injeção e aí já complica tudo.

- Não. Eu posso até deduzir...(....) Quanto à tuberculose, eu não faço idéia, mas imagino que deva ser uma TB que aparece também por falha nos esquemas de tratamento. 
- É a tuberculose que não responde ao tratamento que a gente tem na unidade. Tem alguns casos que temos que recorrer a um lugar especializado, que é o Clemente Ferreira, eles fazem lá o tratamento com drogas mais avançadas para ver se conseguem combater o bacilo da tuberculose, porque já está resistente às drogas comuns.

- A TB multirresistente, o primeiro esquema dela não deu resultado, e ela teve que aderir a outro esquema devido ter falha, de não continuidade da medicação. Voltou mais resistente, e precisa ver que droga ele pode receber. -É uma TB que foi tratada várias vezes e nunca foi feito o tratamento, nunca se conseguiu debelar essa TB. A cada vez que você começa o tratamento de novo, ele está um pouco mais resistente. Ou seja, você terá que adicionar mais uma nova droga a esse processo. Se o paciente para duas, três vezes, $e$ o paciente terá que tomar todas as drogas que tem para TB para ver se consegue tratar, matar esse bichinho.

-Paciente multidrogarresistente também é a mesma história. Ele pode ter a multirresistência por não fazer o tratamento correto de não tomar a medicação corretamente, ou o bacilo já pode ser um bacilo resistente a este tipo de medicação. Então é assim, quando o paciente é resistente, temos que supervisionar para isso se ele realmente toma a medicação, como toma, se ele tem alguma falha de esquecer de tomar, se realmente ele toma, o importante é isso, saber se o paciente realmente toma perceber qual tipo de resistência é. Se é por ele não tomar direito ou se é pelo bacilo ser resistente. É dado um outro tipo de droga a ele e vai depender de como ele vai responder a essa multirresistência; tem o teste de sensibilidade que é feito para saber se o bacilo dele já é resistente, e já é feito na $1^{a}$ vez, quando ele faz o escarro a gente já pede esse teste para saber se o bacilo dele já é resistente. Normalmente isso não existe na rede, não é disponível esse teste por ser um custo alto, então às vezes fica meio... Dificulta o tratamento, pois o paciente começa a tomar medicação depois você vê que os exames dele continuam positivos, porque às vezes o médico vai... Aqui, como temos 
acesso a esse teste, mas na rede tem, mas é demorado, não é tão fácil quanto a gente aqui dentro.

- Têm pacientes que são super difíceis (mas não são muitos) existem pacientes que abandonam muitas vezes o tratamento, tenho uma paciente assim, abandonou o tratamento em menos de um mês, ou porque foi presa ou foi pra rua, ou usa droga, então ela já não está tomando o primeiro esquema. Já é a terceira ou quarta vez que ela começa a tomar remédio para tuberculose e acaba abandonando. Nesse caso, a tuberculose se torna multirresistente. Temos um grupo de adesão, eu oriento, a enfermeira orienta, o pessoal do acolhimento orienta, fazemos grupos e agora estamos tentando o tratamento supervisionado.

- Nós atendemos, porque tem muita gente de hospital, o estado não distribui esse tipo de medicamento, na farmácia hospitalar não tem, já veio muita gente da Santa Casa com a receita, e daí nós atendemos. Só que nós sempre orientamos a pessoa a procurar o posto para fazer o acompanhamento.

Os profissionais não-médicos têm um conhecimento que se pode considerar mais superficial acerca da TB/MDR, e como são os responsáveis por grande parte da orientação dos pacientes acerca da adesão ao tratamento, talvez se beneficiassem com capacitações mais específicas.

De modo geral, o que pode prejudicar a adesão é o fato de atribuírem ao paciente, a responsabilidade única sobre a ingestão de medicamentos, sem considerar o papel do serviço e da rede social na questão da adesão de modo mais crítico. 


\section{CONCLUSÕES E RECOMENDACÕES}

No presente estudo, alguns dados obtidos podem ser importantes subsídios para o estudo da adesão para pacientes com aids, tuberculose e usuários de drogas. Em primeiro lugar, que os preditores de não-adesão para tratamento da aids somam-se aos preditores de não-adesão para o tratamento da tuberculose e a uma pré-avaliação deste usuário como 'não-aderente'. As estratégias de tratamento supervisionado mostraram-se ferramentas importantes para melhorar as possibilidades de não-abandono.

Em segundo lugar, que os pacientes relatam dificuldades em apresentarem sua real condição de usuários de drogas para os profissionais de saúde que os atendem. Quando o fazem, é de modo sutil ou superficial, omitindo quantidade, freqüência e as falhas de ingestão de medicamentos decorrentes de seu uso de drogas.

Em contrapartida, os profissionais de saúde têm como premissa que os usuários de drogas são menos aderentes e trarão dificuldades por questões de 'temperamento' ou caráter. Quando são apresentados ao uso de drogas do paciente, alguns têm como conduta a exigência da abstinência imediata, o que afungenta o paciente. Todos poderiam ser beneficiados com a introdução da estratégia de Redução de Danos como uma ferramenta amais para se atender a esse tipo de paciente, ou mesmo a intensificação dos serviços de DST/Aids com a Saúde Mental.

Um exemplo disso é a constatação que pacientes usuários de crack seguem compartilhando cachimbos, estando com tuberculose pulmonar e outras co-infecções (hepatites), sem comunicar a ninguém do serviço de saúde. O trabalho do redutor de danos poderia ser uma estratégia de acesso a esses pacientes e interrupção da cadeia de transmissão do bacilo e do vírus, respectivamente.

Nos serviços pesquisados, a busca de pacientes que faltam ou abandonam não é padronizada, em alguns casos existe uma combinação inicial - em caso de três faltas nãojustificadas o serviço entraria em contato por telefone ou telegrama - porém não há uma conduta sistematizada, que possa ser efetiva nessa relação do serviço com o paciente. Ainda nos serviços, em função da carga horária de trabalho e das grandes distâncias entre os vários empregos dos profissionais de saúde, não há uma rotina institucionalizada para reuniões com as equipes multiprofissionais. Em relação aos pacientes usuários de drogas 
co-infectados, é uma estratégia importante, pois é freqüente o relato de descrição do uso de drogas para um profissional da equipe que não é o médico, e poderia ser benéfico para a adesão destes pacientes que essa informação fosse considerada para melhoria de seu atendimento.

Em relação à tuberculose, os indicadores epidemiológicos podem ser melhorados com uma comunicação mais efetiva dos casos que são atendidos nos serviços de DST/Aids com os outros serviços de saúde. A orientação para os pacientes e familiares também pode ser incrementada, com busca ativa de contactantes, profilaxia, dentre outras medidas já incorporadas ao cotidiano dos serviços de tuberculose, que podem ser aplicadas como ferramentas de controle da epidemia também nos serviços de aids.

Os pacientes participantes deste estudo, com aids, tuberculose e usuários de drogas apresentam clara piora na adesão em função de seu uso de drogas, seja por comorbidades psiquiátricas (depressão em especial), seja em função dos erros na ingestão de doses de comprimidos (todas as cápsulas de uma vez, falhas nos finais de semana e viagens, tomar à meia-noite para valer para dois dias, dentre outros). A afirmação tomo do meu jeito, e não do jeito que o médico manda simboliza e sintetiza a forma como esses pacientes estão manejando seus tratamentos.

Os pacientes co-infectados não querem fazer o tratamento em locais próximos de suas residências, por medo do preconceito e do estigma. Optam por tratamentos em serviços distantes, o que pode prejudicá-los - os pacientes entrevistados ou estão desempregados ou têm sub-empregos - pela falta de condições de transporte.

Outros problemas importantes apresentados foram os efeitos colaterais, em especial os gastro-intestinais e a lipodistrofia, e no tratamento conjunto com anti-tuberculínicos, a questão das neuropatias periféricas, e a falta de recursos dos pacientes para compreenderem sua situação (que as reações são efeitos colaterais) e a falta de medicamentos básicos na rede pública, ou ainda, falta de condições de transporte de sua residência até o serviço de DST/Aids.

Além dos efeitos colaterais, os pacientes entrevistados consideram a carga viral indetectável como sinônimo de cura, e quando obtêm esse tipo de resultado em algum exame, abandonam a medicação ao menos temporariamente. Faz-se necessário um amplo 
trabalho de esclarecimento junto às pessoas vivendo com HIV e aids para compreensão da necessidade de seqüência do tratamento mesmo na ausência de sintomas e com resultado de carga viral indetectável.

Parece ser prática vigente a avaliação da adesão estar restrita a auto-relato e diagnóstico de exames clínicos, e sugere-se a ampliação destes critérios, que no caso de usuários de drogas podem ser enviesados. Também a apresentação explícita e didática de possíveis efeitos colaterais, pode ser benéfica ao paciente com este perfil.

Uma estratégia que merece atenção é o fato dos pacientes e profissionais de saúde relatarem a troca de serviço como recurso para mudança de esquema terapêutico. Se o paciente apresenta sintomas de efeitos colaterais intensos e não se sente 'bem tratado' pelo profissional de saúde (leia-se insistência para suportar os efeitos ao menos durante três semanas), vai a outro serviço, e não há sistema de vigilância que identifique essa situação. É um grave problema de saúde pública, pois acrescente-se a isso o fato dos prontuários de tuberculose de pacientes que não foram tratados num serviço de DST/Aids em especial não estarem acessíveis aos novos profissionais que irão atender àquele paciente.

Apenas o Serviço SM1 tem parceria local para controle da tuberculose, com Programa Saúde da Família. Essa parceria, bem como outras redes locais de apoio, podem ser benéficas para os pacientes com aids, tuberculose e usuários de drogas.

Em relação à sexualidade destes pacientes, observou-se que tanto o diagnóstico de tuberculose quanto o de aids foram decisivos em um certo "abandono" de sua vida sexual e afetiva. Não há relatos de aconselhamentos ou orientações no serviço de DST/Aids especificamente em relação a esses tópicos. Medo de transmitir tuberculose no beijo, mesmo depois de meses de tratamento, medo de passar aids mesmo em relações sexuais protegidas e renúncia à vida sexual foram dados consensuais entre os entrevistados.

Os conhecimentos dos profissionais de saúde acerca de genotipagem, resistência e falência, sub-tipos de HIV e interações medicamentosas podem ser melhorados com capacitações específicas e acesso às informações por outros meios além da internet. Os profissionais médicos apresentaram conhecimento que pode ser considerado superior ao conhecimento dos profissionais não-médicos, e sendo questões que têm reflexo direto na compreensão do paciente acerca de seu tratamento e adesão, podem ser foco de intervenções. 
Os limites deste estudo referem-se aos limites da pesquisa qualitativa em saúde: os dados não podem ser tomados como referência única, mas como uma parte importante das dinâmicas institucionais vigentes. As recomendações aos gestores, pacientes e profissionais de saúde em geral podem ser incorporadas ao cotidiano e não são excludentes de outras estratégias já vigentes.

Os acréscimos necessários na vigilância, aconselhamento e acompanhamento destes pacientes não demandam aumento de recursos financeiros, mas talvez um redimensionamento de um fluxo já existente, porém não padronizado.

Próximas pesquisas podem aprofundar a questão farmacocinética/ farmacológica, pois muitos dos dados dos esquemas atuais de tratamento da aids e da tuberculose, e a relação destes com os efeitos colaterais relatados e o uso de drogas ainda não foram completamente explorados.

Como recomendação final, a implementação dos Planos Individuais de Adesão para os pacientes com o perfil aids, tuberculose e usuários de drogas, elaborados em conjunto com a equipe multiprofissional e paciente, para permitir compreensão mais apurada dos fatores que atuam como barreiras e dos fatores que poderiam favorecer a adesão. 


\section{BIBLIOGRAFIA}

1. Adão, V. O impacto do diagnóstico HIV+ e Aids: similaridades com stress pós-traumático e propostas de intervenção In Recife: I Congresso Brasileiro de Aids, agosto de 2004. CD ROM.

2. Almeida, E S de. Distritos Sanitários: concepção e organização. Vol. 1. São Paulo: Faculdade de Saúde Pública da Universidade de São Paulo; 1998.

3. Alves, FM. Estudo sobre o controle de comunicantes de pacientes tuberculosos realizado em uma unidade de referência em São Paulo. São Paulo, 1998. [Apresentada a USP. FSP. Departamento de Epidemiologia para obtenção do grau de Mestre].

4. American Society of Addiction Medicine (ASAM). Guidelines for HIV infection and AIDS in Addiction Treatment. Chevy Chase. MD: ASAM, 1998.

5. Amirkhanian $Y$ et al. (2004) Psychosocial needs, mental health, and HIV transmission risk behavior among people living with HIV/Aids in St. Petersburg, Russia. AIDS. 17 (16):2367-74.

6. Andrade, TM (2003). Redução de Danos: um novo paradigma?. Paper.

7. Angelino AF, Treisman GJ. Management of psychiatric disorders in patients infected with HIV. Clin Infect Diseases 2001; 33(6):847-56.

8. Arantes, GR. Contribuição para a integração das atividades antituberculose nas unidades sanitárias do estado de São Paulo. São Paulo, 1972. [Mestrado, Faculdade de Saúde Pública da USP]

9. Ayres, JRCM. Vulnerabilidade e adolescência. Paper, 1999.

10. Bandura AJ, Simon KM. The role of proximal intentions in self-regulation of refractory behavior. Cognitive Therapy and Research 1977. 1: 177-184.

11. Bangsberg DR et al. Adherence to protease inhibitors, HIV-1 viral load, and development of drug resistance in an indigent population. AIDS. 2000, 14:357366. 
12. Bass JB et al. Treatment of tuberculosis and tuberculosis infection in adults and children. American Thoracic Society and The Centers for Disease Control and Prevention. American Journal of Respiratory \& Critical Care Medicine 1994, 149:13559-1374.

13. Batki SL, Gruber VA, Bradley JM et al 2002. A controlled trial of methadone treatment combined with directly observed isoniazid for tuberculosis prevention in injection drug users. Drug Alcohol Depend 66:283-293.

14. Batki SL \& Selwyn PA (org). Substance Abuse Treatment for Persons with HIV/Aids. Treatment Improvement Protocol Series (TIPS) \# 37. US; Department of Health and Human Services, 2000.

15. Bayer, R. Winkingson.D. Directly observed therapy for tuberculosis: history of an idea. Lancet 1995, 345:1545-1548.

16. Berlinguer, G. A ética na saúde. São Paulo: Editora Hucitec; 1996.

17. Beauchesne, H. História da Psicopatologia. São Paulo: Martins Fontes, 1989.

18. Betarello SV (org) - Perspectivas psicodinâmicas em psiquiatria. São Paulo: Lemos Editorial, 1998.

19. Biagolini, R, Rodrigues, A; Diagnóstico educativo de tuberculose, em uma Unidade Básica de Saúde da Prefeitura do Município de São Paulo, Administração Regional de Saúde 06 - São Paulo. VII Congresso da Associação Paulista de Saúde Pública: saúde e democracia. Santos, APSP, 2001. p115.

20. Boccelari AA, Dilley JW, Chambers DB et al. Immune function and neuropsychological performance in HIV-1-infected homosexual men. Journal Acquired Immune Deficiency Syndrome 1933; 6(6):592-601.

21. Branco, BC, Souza, RL, Diniz, RV, Melo, FC. O problema da não-adesão ao tratamento da tuberculose. Pulmão Rio de Janeiro; 8 (4) 319-26, out-dez, 1999.

22. Brasil, Portaria n. ${ }^{\circ}$ 263/GM de 5 de fevereiro de 2002. Estabelece mecanismos para organizar, articular e integrar as ações voltadas à prevenção e ao controle das hepatites. 
23. Brasil. Constituição: República Federativa do Brasil. Brasília: Senado Federal, Centro Gráfico, 1988.

24. Brawley 1r, Culos-Reed N. Studying adherence to therapeutic regimens: overview, theories, recommendations. Controlled Clinical Trials 2000; 21:156s-163s.

25. Bush PJ, Spector KK, Rabin DI. Use of sedatives and hypnotics prescribed in a family practice. Southern Medical Journal 1984, 77:677-681.

26. CAPUANO, Daniel Antonio, WARD, Jamile Kassis, FORTES, Caio Quintela et al. Busca ativa de casos de tuberculose pulmonar em uma unidade de atendimento em farmacodependência no Município de São Paulo (agosto de 1999 a agosto de 2000). Rev. bras. epidemiol., set. 2003, vol.6, no.3, p.255-261. ISSN 1415-790X.

27. Carvalho, CV, Duarte, DB, Merchán-Hamann, E., Bicudo, E., Laguardia, J. Determinantes da aderência à terapia anti-retroviral combinada em Brasília, Distrito Federal, Brasil. Cadernos de Saúde Pública 1999-2000; 19(2):593-604.

28. CDC. Hepatitis B virus: a comprehensive strategy for eliminating transmission in the United States through universal childhood vaccination (ACIP). Management. Morbidity and Mortality Weekly Report 1991; 40 (no. RR-13) 1-25.

29. Center for Substance Abuse Treatment. Assessment and Treatment of Patients with Coexisting Mental Illness and Alcohol and Other Drug Abuse. Treatment Improvement Protocol (TIP) Series, \# 9. DHHS Pub. No. (SMA) 94-2078. Washington, DC: US Government Printing Office, 1994.

30. Chaulk CP, Kazandijan VA. Directly observed therapy for treatment completion of pulmonary tuberculosis: Consensus Statement of the Public Health Tuberculosis Guidelines Panel. Journal of the American Mewdical Association, 1998, 279:943-948.

31. Clarke, $\mathrm{S}$ et al. Assessing limiting factors to the acceptance of antiretroviral therapy in a large cohort of injecting drug users. British HIV Association HIV Medicine 2003; 4, 33-37. 
32. Conrad P. The meaning of medication: another look at compliance. Social Science and Medicine 1985, 20 (1):29-37.

33. Costa, MA. Medicação supervisionada: um trabalho em equipe, centrado no paciente. Curitiba, Divulgação Saúde Debate 2000, (19):85-7.

34. Cramer, JA, Mattson RH. Monitoring compliance with antiepileptic drug therapy. In: Cramer, JA, Spilker B eds. Patient compliance in medical practice and clinical trials. New York, Raven Press 1991:123-137.

35. Daniel, H. Vida depois da Aids. São Paulo: Iglu Editora, 1982.

36. Dejours, C. Por um novo conceito de saúde In Revista Brasileira de Saúde Ocupacional 1986; 14: 121-126.

37. Deheinzelin, D et al. Fatores preditivos de abandono de tratamento por pacientes com tuberculose. Revista do Hospital das Clínicas da Faculdade de Medicina da USP 1996; 51(4): 131-5 jul-ago..

38. Des Jarlais DC, Friedman SR, Perlis T et al. Risk behavior and HIV infection among new injectors users in the era of AIDS in New York City. Journal of AIDS $1999,16: 75-83$.

39. Dick $\mathbf{J}$ et al. Development of a health education booklet to enhance adherence to tuberculosis treatment. Tuberculosis \& Lung Disease 1996, 77:173-177.

40. Di Girólamo, MM. Influência do serviço de saúde na adesão dos usuários portadores de HIV/Aids no Centro de Referência de DST/Aids no Jardim Mitsutani, no Município de São Paulo. São Paulo, 2000 [Mestrado Departamento de Saúde Materno-Infantil, FSP/USP]

41. Di Matteo MR, Di Nicola DD. Achieving patient compliance. New York, Pergamon, 1982.

42. Dowell J, Hudson H. A qualitative study of medication-taking behaviour in primary care. Family Practice 1997; 14 (5):369-375. 
43. Eldred et al. Adherence to antiretroviral and pneumocistis prophylaxis in HIV disease. Journal of Acquired Immune Deficiency Syndromes, 1998, 18:117125.

44. Enarson D. et al. Management of tuberculosis: a guide for low income countries. $5^{\text {th }}$ ed. Paris, International Union Against Tuberculosis and Lung Disease, 2000.

45. Engelke, $\mathrm{F}$ e Moraes, $\mathrm{V}$. Interações Medicamentosas dos anti-retrovirais ( $1^{\mathrm{a}}$ parte). Jornal Brasileiro de Aids 2005; 6(5) 189-236 set-out.

46. Escohotado, A. Historia General de las drogas. Madrid: Espasa, 2000.

47. Farmer, KC. Methods for measuring and monitoring medication regimen adherence in clinical trials and clinical practice. Clinical Therapeutics 1999, 21:1074-1090.

48. Ferreira, CT, Silveira, TR. Hepatites virais: aspectos da epidemiologia e da prevenção. Revista Brasileira de Epidemiologia 2004; 7(4):473-87.

49. Ferrer, X; Kirschbaum, A; Toro, J; Jadue, J; Muñoz, M; Espinoza, A. Adherencia al tratamiento de la tuberculosis del adulto em Santiago, Chile. Bol.Oficina Sanit.Panam 2001; 111 (5): 423-31, nov.

50. Galvão, J. Cap. 14, Aids e o Ativismo: o surgimento e a Construção de Novas Formas de Solidariedade. In Parker, R. Aids no Brasil. Rio de Janeiro: Hucitec, 1994 (História Social da Aids; nº2).

51. Gir, E; Vaichulonis, CG; Oliveira, MD. Adhesion to anti-retroviral therapy by individuals with HIV/AIDS attended at an institution in the interior of São Paulo. Revista Latino-Americana de Enfermagem 2005; Sep./Oct., 13: 5: 634-641.

52. Guimarães, MDC. Estudo temporal das doenças associadas à AIDS no Brasil, 1980-1999. Cadernos de Saúde Pública; 2000, Rio de Janeiro, 16 (sup 1) 21-36.

53. Haynes RB. Determinants of compliance: the disease and the mechanics of treatment. Baltimore MD, Johns Hopkins University Press, 1979.

54. Hijjar, M.A. Tuberculose: problema atual. JBM 1994; 66: 123-45. 
55. Ho, DD et al. Rapid turnover of plasma virions and CD4 lymphocytes in HIV-1 infection. Nature 1995, 373:123-126.

56. Horne R. Weinman J. Patient's beliefs about prescribed medicines and their role in adherence to treatment in chronic physical illness. Journal of Psychossomatic Research, 1999, 47:555-567.

57. Ingersoll, K. The impact of psychiatric symptoms, drug use, and medication regimen on non-adherence to HIV treatment. Aids Care (February 2004) vol 16, no. 2, pp 199-211.

58. Kanai, RMT.; Camargo, EAl. Terapia de aderência anti-retroviral. Jornal Brasileiro de Medicina 82 (1/2):14-20, jan-fev 2002.

59. Kaplan, EM. Antidepressant noncompliance as a factor in the discontination syndrome. Journal of Clinical Psychiatrics 1997, 58:31-35.

60. Kerr-Pontes, LRS. Comportamento Epidemiológico da infecção pelo vírus da imunodeficiência humana na região de Ribeirão Preto, 1984 a 1991. Ribeirão Preto, 1992 [Tese de Doutoramento - Faculdade de Medicina de Ribeirão Preto da USP].

61. Kerr-Pontes, LRS, Oliveira, FAS and Freire, CA M. Tuberculosis associated with AIDS: the position in a Northeastern region of Brazil. Rev. Saúde Pública 1997; vol.31, no.4, p.323-329

62. Kessler RC, Nelson CB, Mc Gonagle KA et al. The epidemiology of co-occurring addictive and mental disorders: implications for prevention and services utilization. American Journal of Orthopsychiatry 1996; 66(1):17-31.

63. Kessler RC, Nelson CB, Mc Gonagle KA et al. The epidemiology of co-occurring addictive and mental disorders: implications for prevention and services utilization. American Journal of Orthopsychiatry 1996; 66(1):17-31.

64. Knechten, H. - State-of-art in HIV viral load monitoring and the LCx assay. In: Seventh European Conference on Clinical Aspects and Treatment of HIV Infection; 1999. Lisbon, Portugal, 23-27 October. Abstract 04 (CD ROM). 
65. Laranjeira, R. (org) Usuários de substâncias psicoativas: abordagem, diagnóstico e tratamento. São Paulo: Conselho Regional de Medicina do Estado de São Paulo/ Associação Médica Brasileira, 2003.

66. Leite, F. País descumpre meta de curar tuberculose. Folha de São Paulo, 24/03/2006, caderno cotidiano.

67. Leite, SN e Vasconcellos, MPC. Adesão à terapêutica medicamentosa: elementos para a discussão de conceitos e pressupostos adotados na literatura/ Adherence to precribed therapy: points for concepts and pressuppositions discussion. Ciênc. Saúde coletiva; 8 (3): 775 - 782, 2003.

68. Leventhal, H., Cameron L. Behavioral theories and the problem of compliance. Patient Education and Counseling 1987, 10:117-138.

69. Liefooghe $\mathrm{R}$ et al. Perception and social consequences of tuberculosis: a focus group study of tuberculosis patients in Sialkot, Pakistan. Social Science \& Medicine 1995, 41:1685-1692.

70. Lignani, L, Greco DB; Carneiro, M. Avaliação da aderência aos anti-retrovirais em pacientes com infecção pelo HIV/Aids. Revista de Saúde Pública 35(6):495501, dez 2001.

71. Lima, HMM. Ah.. mas eu não sou do grupo de risco! A Prevenção às DST/Aids entre jovens universitários de São Paulo - Capital.. São Paulo, 2000. [Dissertação de Mestrado em Psicologia Social - Pontifícia Universidade Católica de São Paulo].

72. Lima, HMM. Rigor e Visibilidade em Metodologia Qualitativa in Práticas Discursivas e Produção de Sentidos no Cotidiano. São Paulo:Cortez, 2002a.

73. Lima, HMM. The rejection of health professionals to Harm Reduction. São Paulo, Brazil.In XIV International Conference; 2002b jul 7-12; Barcelona (Espanha).

74. Lima, HMM Training Health Professionals to work in Harm Reduction. XIV Harm Reduction Conference - Chiang Mai, Thailand 2003a

75. Lima, HMM Learning Harm Reduction in College - Sao Paulo. XIV Harm Reduction Conference - Chiang Mai, Thailand 2003b 
76. Lima, HMM Relatório final. Rapid Assessment, Response and Evaluation among Vulnerable Population in Brazil. Brasília: Programa Nacional de DST/Aids, 2005a.

77. Lima, HMM e Malta, M. Guia para profissionais de saúde - atendimento a pacientes HIV+ usuários de drogas na rede pública de saúde. Washington DC; OPAS (no prelo), 2005b.

78. Lyketsos CG, Hanson AL, Fishmann M et al. Maniac syndrome early and late in the course of HIV. Am J Psychiatry 1993;150(2) 326-7.

79. Malta, M., Petersen, M. Clair, S. Freitas, F. Bastos, F. I. Adherence to antiretroviral therapy: a qualitative study with physicians from Rio de Janeiro, Brazil. Cadernos de Saúde Pública Sept/Oct. 2005; Rio de Janeiro, 21 (5):14241432, set-out.

80. Manual de diagnóstico e estatística de distúrbios mentais DSM IV. São Paulo: Manole, 1999.

81. Martin, D. Mulheres e aids: uma abordagem antropológica. São Paulo; 1995. [Dissertação de Mestrado. Departamento de Antropologia da Faculdade de Filosofia, Ciências e Letras da USP].

82. Mello, CEB, Pires MMA. A co-infecção pelos vírus da Hepatite C (HCV) e da Imunodeficiência Humana (HIV) - Aspectos Clínicos e Terapêuticos. Moderna Hepatologia 2004; Ano 30: Edição Especial.

83. Michalizen, M. S. O calidoscópio e a rede: estratégias e práticas de prevenção à aids e ao Uso Indevido de Drogas. São Paulo; 1999.[Tese de Doutorado em Ciências Sociais PUC/SP].

84. Milstein-Moscati I, Persano \& Castro LLC. Aspectos metodológicos e comportamentais da adesão à terapêutica, pp 171-179. In LCC Castro (org) Fundamentos de farmacoepidemiologia. AG Editora, [S.L.], 2000.

85. Minayo, MCS. O Desafio do Conhecimento: pesquisa qualitativa em saúde. São Paulo: Hucitec, 2004. 
86. Ministério da Saúde. Coordenação Nacional de DST e Aids. Aderência ao tratamento por Anti-retrovirais. Brasília (DF); 2000a.

87. Ministério da Saúde. Coordenação Nacional de DST e Aids. Legislação DST e AIDS no Brasil. Brasília: Ministério da Saúde, 2000b, 3v. (v 2 - Normas Federais).

88. Ministério da Saúde. Programa Nacional de DST e Aids. Manual de Redução de Danos.Brasília: Ministério da Saúde, 2001.

89. Ministério da Saúde - Programa Nacional de Hepatites Virais. Avaliação da Assistência as Hepatites Virais no Brasil. Brasília (DF); 2002a, 1-61.

90. Ministério da Saúde. Fundação Nacional de Saúde. Centro de Referência Prof. Hélio Fraga. Sociedade Brasileira de Pneumologia e Tisiologia. Controle da tuberculose: uma proposta de integração ensino-serviço. Rio de Janeiro: FUNASA/CRPHF/SBPT, 2002 b.

91. Ministério da Saúde. Programa Nacional de DST e Aids Critérios para definição de casos de aids. Brasília (DF); $2003 \mathrm{a}$.

92. Ministério da Saúde. Coordenação Nacional de DST/Aids. Aconselhamento em DST/AIDS: princípios e diretrizes. Brasília (DF); $2003 \mathrm{~b}$.

93. Ministério da Saúde. Programa Nacional de DST e Aids Boletim Epidemiológico - Aids e DST. Ano I - no 1 - 01ª - 26a Brasília (DF); 2004a.

94. Ministério da Saúde. Secretaria de Vigilância em Saúde. Programa Nacional de DST e Aids. Recomendações para Terapia anti-retroviral em Adultos e Adolescentes infectados pelo HIV. Brasília (DF); 2004 b.

95. Ministério da Saúde. Programa Nacional de DST e Aids Boletim Epidemiológico

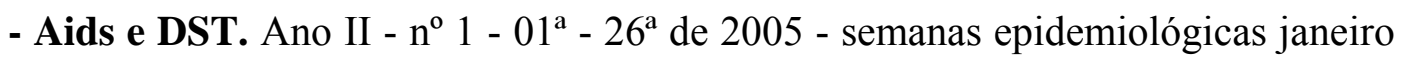
a junho de 2005. Brasília (DF), 2005a.

96. Ministério da Saúde. Secretaria de Vigilância em Saúde. Programa Nacional de DST e Aids. Recomendações para Terapia anti-retroviral em Adultos e Adolescentes infectados pelo HIV. Brasília (DF); 2005 b. 
97. Ministério da Saúde. Programa Nacional para a Prevenção e o Controle das Hepatites Virais. Disponível no endereço $<\mathrm{URL}:$ http://www.saude.gov.br/sps/areastecnicas/hepatite.htm>.

98. Mirim, LYL. A Construção do sentido do teste HIV: uma leitura psicossocial da literatura médica. São Paulo; 1998 [Dissertação de Mestrado em Psicologia Social PUC/SP].

99. Montaner JSG et al. A randomized, double-blind trial comparing combinations of nevirapine, didanosina, and zidovudina for HIV-infected patients: the INCAS Trial. Journal of the American Medical Association 1998, 279:930-937.

100. Morse EV. Et al. Determinants of subject compliance within an experimental antiHIV drug protocol. Social Science \& Medicine 1991, 32:1161-1167.

101. Mulligan, RC. The basic science of gene therapy. Science \& Medicine 1988; 27:683-689.

102. Muniz, Jordana Nogueira; Villa, Tereza Cristina Scatena; Monroe, Aline Aparecida; Hino, Paula. Construindo e organizando a prática do tratamento supervisionado no controle da tuberculose. Espaço para saúde: versão on line 2(2) jun.2001.<url http://www.ccs.br/espacoparasaude/v2n2.

103. Murai, Hogla Cardozo. AIDS, drogas de abuso e o perfil epidemiológico da tubeculose no município de Itajaí, Santa Catarina, 1983-1996. São Paulo, 2001 [138]. [Apresentada a USP, FSP, Departamento de Epidemiologia para obtenção do grau de Doutor].

104. Needle, R.A. Rapid Assessment, Response and Evaluation: training workbook. NY: Department of Health Services, 2002.

105. Nemes, MIB, Carvalho, HB. e Souza, MFM. Antiretroviral therapy adherence in Brazil. AIDS 2004, 18 (suppl 3): S15-S20.

106. Nemes, MIB (org). Aderência ao tratamento por Anti-Retrovirais no Estado de São Paulo. Série Avaliação, Brasília (DF), Ministério da Saúde, 2000. 
107. New York State Department of Health. Promoting GYN care for HIV infected women. New York; 2000. AIDS Institute.

108. Nogueira, P A; Malucelli, MICA, Regina M; Almeida, MMMB de. Avaliação das informações de tuberculose (1989-1999) de um Centro de Saúde Escola da Cidade de São Paulo. Revista Brasileira de Epidemiologia 2001; 4(2):131-138, ago.

109. Nunnally JC, Bernstein IH. Pshychometric theory, $3^{\text {rd }}$ ed. New York. Mc GrawHill, 1994.

110. Okamura, MN. Perfil epidemiológico dos pacientes com tuberculose atendidos em hospital geral universitário 1999-2001. São Paulo:2003. [Apresentada a USP. FSP. Departamento de Epidemiologia para obtenção do grau de Mestre].

111. Oliveira, H de e Moreira Filho, DC. Retreatment of tuberculosis: aspectos of previous episodes, Brazil, 1993-1994. Revista de Saúde Pública 2000; 35(5), P. 437-443.

112. Organização Mundial da Saúde - CID 10/ Organização Mundial de Saúde; tradução Centro Colaborador da OMS para a Classificação das Doenças em Português. São Paulo: Editora da Universidade de São Paulo, 1994.

113. Orozco, L; Hernandez, R. Usta, C; Alçean, M; Camargo, D. Fatores de riesgo para el abandono (no adherencia) del Tratamiento Antituberculoso. Med. UIS 1998; 12 (4): 169-72 jul-ago.

114. Owing Mills. Dictionary of health services management, $2^{\text {nd }}$. ed., MD, National Health Publishing, 1982.

115. Palepu, A et al Uptake and adherence to highly active antiretroviral therapy among HIV-infected people with alcohol and other substance use problems: the impact of substance abuse treatment. In Addiccion, 99 (2004), 361-368.

116. Parker, R.(org) A Aids no Brasil (1982-1992). Rio de Janeiro. Relume-Dumará: ABIA: IMS-UERJ. (História Social da Aids; 2), 1994.

117. Paterson DL et al. Adherence to protease inhibitor therapy and outcomes in patients with HIV infection. Annals of Internal Medicine 2000; 133:21-30. 
118. Perelson AS et al. HIV-1 dynamics in vivo: virion clearance rate, infected cell lifespan, and viral generation time. Science 1996; 271:1582-1586.

119. Pinho, JL. Tratamento supervisionado em tuberculose no município de Taboão da Serra, São Paulo, 1998-1999. São Paulo, 2000. [Mestado, Faculdade de Saúde Pública da USP/SP].

120. Pinho, JL, Nogueira, PA. Tratamento supervisionado de tuberculose no minicípio de Taboão da Serra, 1998-2000.VII Congresso Paulista de Saúde Pública: saúde e democracia. Santos, 2001 p114.

121. Pompéia, JA. Aspectos fenomenológicos da drogadicção. Paper, 1996.

122. Rachid, M. e Schechter. Manual de HIV/ Aids. 7 ed. Rio de Janeiro: Revinter, 2003.

123. Rand CS. Measuring adherence with therapy for chronic diseases: implications for the treatment of heterozygous familial hypercholesterolemia. American Journal of Cardiology 1993; 72:68D-74D.

124. Raviglione M, Pio A. Evolution of WHO Policies for tuberculosis control, 19482001. Lancet 2002; 359:775-780.

125. Ribeiro, S A.; Amado, VM.; Camelier, AA.; Fernandes, MMA.; Schenkman, S. Estudo caso-controle de indicadores de abandono em doentes de tuberculose. $\mathbf{J}$ Pneumol 2000; 26(6):291-296, nov-dez.

126. Robbins, JL, Phillips KD, Dudgeon WD, Hand GA. Physiological and psychological correlates of sleep in HIV infection. Clin Nurs Res 2004; 13 (1):3352.

127. Rogers, R., Prentice-Dunn S. Protection Motivation Theory. In: Gochman G. ed. Handbook of health behavior research. Vol 1. Determinants of Health Behavior: personal and social. New York, NY, Plenum, 1997.

128. Rolfs RT, Goldberg M. Sharrar RG (1990). Risk factors for syphilis: cocaine and prostitution. American Journal of Public Health 80:853-857.

129. Rosner, B. Fundamentals of biostatistics 4th ed., Belmont: Duxbury Press. 1995. 
130. Secretaria Estadual de Saúde do Ceará. Departamento de Saúde Pública. Análise epidemiológica da tuberculose no Estado do Ceará em 1993. Fortaleza (CE); 1993.

131. Seibel, SD. Comorbidade Psiquiátrica In TOSCANO, A. Dependência de drogas. São Paulo: Editora Atheneu, 2002.

132. Sendrail, M. Historie Culturelle de la Maladie. Toulouse: Privat, 1980.

133. Simmonds P, Zhang LQ, Watson HG, Rebus S. Ferguson ED, Balfe P et al. Hepatitis $\mathrm{C}$ quantifications and sequencing in blood products, hemophiliacs and drug users. Lancet 1990; 336: 1469-72

134. Skinner, BF. The behavior of organisms. New York, Appleton-Century-Crofts, 1938.

135. Song, ATW; Schout, D; Novaes, H M D; Goldbaum, M. Clinical and Epidemiological features of Aids/tb comorbidity. Revista do Hosp. Clin. Fac. Med USP 2003; 58 (4):207-214.

136. Spink, MJP. Prevenção. In A Resposta Brasileira ao HIV/AIDS: Experiências Exemplares. Brasília: Coordenação Nacional de DST e Aids, 1999.

137. SPSS 11.0 (2005) - Disponível em $<$ URL:http://www.spss.com/spss/brochures.htm>

138. Stimson, G. RAR Methodology - Rapid Assesment and Response. Centre for Research on Drug and Health Behaviour, Imperial College School of Science. London, United Kington, 2000.

139. Stone, VE et al. HIV/Aids patients'perspectives on adhering to regimens containing protease inhibitors. Journal of General Internal Medicine 1998: 13:586-593.

140. Suleiman, J. Aderência entre pacientes com lipodistrofia. Paper, 2005.

141. Sumartojo E. When tuberculosis fails. A social behavioral account of patient adherence. American Review of Respiratory Disease 1993: 147:1311-1320. 
142. Toledo Júnior, ACC. Tuberculose: doença reemergente ou epidêmica? Revista Médica de Minas Gerais 1998; 8(1)?:20-3, jan-mar.

143. Toscano, A. Dependência de drogas. São Paulo: Editora Atheneu, 2002.

144. Trotter, R. RARE Methodology and Qualitative Analysis. Paper, 2003.

145. Tsoukleris, J. Adherence to Long-Term Therapies: Evidence for Action. The Annals of Pharmacotherapy 2004; 38: 1093

146. Vitolins, $M Z$ et al. Measuring adherence to behavioral and medical interventions. Controlled Clinical Trials 2000; 21:188S-194S.

147. Webb DG, Horne R, Pinching AJ. Treatment-related empowerment: preliminary evaluation of a new measure in patients with advanced HIV disease. International Journal of STD \& Aids 2001; 12:103-107.

148. Weiden P. Adherence to antipsychotic medication: key facts. Schizophrenia Home Page, 2002 (<URL:http://www.schizophrenia.com/ami/coping/noncompli2.htm>).

149. Wenger $\mathrm{N}$ et al. Patient characteristics and attitudes associated with anti-retroviral (AR) adherence. Abstract. $N^{\circ}$ 98. Presented at the VI Conference on retrovirus and opportunistic infections. Washington DC, 1999.

150. Whitefield SG, Everett AS, Rein MF. Mania and AIDS. American Journal of Psychiatry 1992; 149(4):583-4.

151. WHO 1997. WHO adherence project: towards policies for action. Treatment of tuberculosis: guidelines for National Programmes. Geneva, WHO, 1997 (document WHO/TB/94.177)

152. WHO 2001. WHO adherence project: towards policies for action. Adherence to Long-term Therapies: evidence for action. Org. Eduardo Sabaté, 2001. Disponível no site $<$ URL:http://www.who.org $>$.

153. WHO 2003. WHO adherence project: towards policies for action. Adherence to long-term therapies: evidence for action. Org. Eduardo Sabaté, 2003. Disponível no site <URL:http://www.who.org>.

154. WHO 2004. TB/HIB: a clinical manual. Geneva, 2004. 
155. Wood, E. et al Elevated rates of antiretroviral treatment discontinuation among HIV-infected injection drug users: implications for drug policy and public health. International Journal of Drug Policy, 15 (2004) 133-138.

156. World Health Organization (WHO). Tuberculosis. Disponível em <URL:http://www.who.int/inf-fs/em/fact104.html>. [April, 2000].

157. Yach D. Tuberculosis in the Western Cape health region of South Africa. Social Science \& Medicine 1988; 27:683-689.

158. Zampieri, AMF. Sociodrama da aids. São Paulo, 1996 [Mestrado em Psicologia Clínica, PUC/SP]. 


\section{ANEXO 1 - ACONSELHAMENTO PRÉ E PÓS-TESTE DIRETRIZES - MINISTÉRIO DA SAÚDE}

\section{a) Aconselhamento pré-teste anti-HIV}

No aconselhamento pré-teste anti HIV, ainda segundo as diretrizes do Programa Nacional de DST/Aids (MINISTÉRIO DA SAÚDE, 1997), o profissional de saúde pode ser um facilitador do processo:

1. avaliar com o paciente a realização ou não do teste; reafirmar o caráter voluntário e confidencial da testagem; avaliar junto ao paciente qual o apoio emocional e social disponível (família, parceiros, amigos, trabalho e outros), qual a história anterior de testagem e comportamentos de risco; informar sobre o teste e explicar o conceito de janela imunológica, certificando-se de que o usuário compreendeu;

2. informar o paciente sobre o significado dos possíveis resultados do teste; reforçar para o paciente a diferença entre HIV e aids, entre ser portador do HIV e doente de aids;

3. considerar com o paciente o impacto em sua vida dos possíveis resultados do teste anti-HIV; considerar com o paciente possíveis reações emocionais no período de espera do resultado do teste; reforçar a necessidade da adoção de práticas seguras frente ao HIV, também neste período;

4. no caso de paciente co-infectado por tuberculose, explicar as formas de quimioprofilaxia, a necessidade de busca de contactantes e do paciente-fonte.

\section{b) Aconselhamento pós-teste anti-HIV:}

\section{b.1) Aconselhamento pós-teste anti-HIV com resultado negativo:}

1 informar que um resultado negativo significa que a pessoa não está infectada ou foi infectada tão recentemente, que não produziu anticorpos necessários para detecção pelo teste utilizado; avaliar a possibilidade do paciente estar em "janela imunológica" e necessitar de um novo teste; lembrar que um resultado negativo não 
significa imunidade;

2 reforçar as práticas seguras já adotadas pelo usuário frente ao $\mathrm{HIV}$, os benefícios do uso exclusivo de equipamentos para o consumo de drogas injetáveis e demonstrar o método correto de limpeza e desinfecção de seringas e agulhas para usuários de drogas injetáveis.

\section{b.2) Aconselhamento pós-teste com resultado positivo:}

1. permitir o tempo necessário para que o paciente assimile o impacto do diagnóstico e expresse seus sentimentos; conversar sobre sentimentos e dúvidas, prestando o apoio emocional necessário; estar atento para o manejo adequado de sentimentos comuns, tais como raiva, ansiedade, depressão, medo, negação e outros;

2. desmistificar sentimentos que associam HIV/AIDS à culpa, à punição, à rejeição, à degenerescência, à morte, dentre outros; retomar que um resultado positivo significa que a pessoa é portadora do vírus, podendo ou não estar com a doença desenvolvida;

3. enfatizar que mesmo, sendo um portador assintomático, pode transmitir o vírus para outros - e reforçar com ele a necessidade da adoção de práticas seguras para a redução de riscos de re-infecção pelo HIV e outras DST, o benefício do uso, as formas corretas de colocação, retirada e descarte do preservativo.

4. reforçar a importância de acompanhamento médico, ressaltando que a infecção é controlável; enfatizar a necessidade do resultado ser comunicado aos parceiros sexuais oferecendo ajuda, caso seja solicitada; orientar quanto à necessidade dos parceiros realizarem o teste anti-HIV;

5. orientar o paciente a respeito dos serviços de assistência necessários, disponíveis na região, incluindo grupos comunitários de apoio. 


\section{ANEXO 2 - TRATAMENTO DE PACIENTES HIV+ COM TUBERCULOSE}

\section{QUADRO 1 : RECOMENDAÇÕES TERAPÊUTICAS PARA PACIENTES HIV+ COM TUBERCULOSE}

\begin{tabular}{|c|c|}
\hline SITUAÇÃO & RECOMENDAÇÃO \\
\hline $\begin{array}{l}\text { Paciente virgem de tratamento para } \\
\text { tuberculose e para HIV }\end{array}$ & $\begin{array}{l}\text { Tratar TBC por seis meses com esquema I (E- } \\
\text { 1) }{ }^{(1)} \text { recomendado pelo Ministério da Saúde. } \\
\text { Após a estabilidade clínica }{ }^{(2)} \text {, determinar } \\
\text { contagem de linfócitos T CD4+e carga viral } \\
\text { para avaliar necessidade de TARV }{ }^{(3)} \text {. Caso } \\
\text { indicada TARV, iniciar com um dos seguintes } \\
\text { esquemas }{ }^{(4,5)} \text { : } \\
\text { - } 2 \text { ITRN + EFZ } \\
\text { - } 2 \text { ITRN + SQV/RTV }\end{array}$ \\
\hline $\begin{array}{l}\text { Paciente sob terapia anti-retroviral, } \\
\text { virgem de tratamento para tuberculose }\end{array}$ & $\begin{array}{l}\text { Tratar TBC por seis meses com esquema I (E- } \\
1)^{(1)} \text { recomendado pelo Ministério da Saúde. } \\
\text { Caso necessário, adequar TARV, substituindo } \\
\text { drogas incompatíveis com o uso de } \\
\text { rifampicina e utilizando um dos seguintes } \\
\text { esquemas }{ }^{(4,5,6)} \text { : } \\
\text { - } \quad 2 \text { ITRN + EFZ ou } 2 \text { ITRN + SQV/RTV }\end{array}$ \\
\hline Meningoencefalite tuberculosa & $\begin{array}{l}\text { Tratar TBC por nove meses, com esquema II } \\
(\mathrm{E}-2)^{(7)} \text { recomendado pelo Ministério da } \\
\text { Saúde. Iniciar ou substituir a TARV por } \\
\text { esquemas compatíveis com uso concomitante } \\
\text { de rifampicina }{ }^{(4,5,6)} \text { : } \\
\text { - } \quad 2 \text { ITRN + EFZ ou } 2 \text { ITRN + SQV/RTV }\end{array}$ \\
\hline Retratamento para tuberculose & $\begin{array}{l}\text { Tratar TBC por seis meses, com esquema I } \\
\text { reforçado - IR }(\mathrm{E}-1 \mathrm{R}){ }^{(8,9)} \text {, recomendado pelo } \\
\text { Ministério da Saúde. Iniciar ou substituir a } \\
\text { terapia anti-retroviral por esquemas } \\
\text { compatíveis com uso concomitante de } \mathrm{RMP}^{(4,}, \\
5, \mathrm{~S}\end{array}$ \\
\hline Falência ao tratamento para tuberculose & $\begin{array}{l}\text { - } 2 \text { ITRN }+ \text { EFZ ou } 2 \text { ITRN + SQV/RTV } \\
\text { Tratar TBC por } 12 \text { meses, com esquema III } \\
\left(\text { E-3) }{ }^{(9,10)} \text { recomendado pelo Ministério da }\right. \\
\text { Saúde. Iniciar ou substituir TARV pelo } \\
\text { esquema considerado mais adequado do ponto } \\
\text { de vista imunológico e virológico. }\end{array}$ \\
\hline Tuberculose multidroga-resistente & $\begin{array}{l}\text { Encaminhar aos serviços de referência em } \\
\text { tuberculose, para avaliação de especialista e } \\
\text { uso de esquemas especiais. }\end{array}$ \\
\hline
\end{tabular}


1. Dois meses iniciais com $\mathrm{R}+\mathrm{H}+\mathrm{Z}$, seguidos de quatro meses com $\mathrm{R}+\mathrm{H}(2 \mathrm{RHZ} / 4 \mathrm{RH})$.

2. A tuberculose freqüentemente promove elevação da carga viral e diminuição da contagem de células T-CD4+ em pacientes HIV+, daí a recomendação de aguardar 30 a 60 dias para a avaliação imunológica e virológica.

3. A terapia anti-retroviral (TARV) está indicada para todos os pacientes sintomáticos em relação ao HIV (ver quadro III) ou que tenham contagem de linfócitos T-CD4+ abaixo de $200 / \mathrm{mm}^{3}$. Para assintomáticos com contagem de linfócitos T-CD4+ entre 200 e $350 / \mathrm{mm}^{3}$, considerar início da TARV, ponderando risco de evolução da infecção pelo HIV (particularmente se carga viral acima de 100.000 cópias $/ \mathrm{ml}$ ), risco de toxicidade e capacidade de adesão relacionados a ambos tratamentos. Considerar adiamento do início da TARV em casos de imunodeficiência menos graves. Ver indicações de TARV no quadro I.

4. Não há dados que permitam escolher entre esquemas com ITRNN ou IP. O uso de ritonavir ou de nevirapina associado ao esquema I está associado a risco aumentado de hepatotoxicidade. As transaminases e outras provas de função hepática do paciente devem ser cuidadosamente monitoradas durante o tratamento e não iniciar o uso de esquema com ritonavir ou nevirapina associado ao esquema I (E-1), caso os níveis basais dessas enzimas hepáticas estejam três vezes acima dos valores de referência. $\mathrm{O}$ efavirenz é contra-indicado na gestação podendo ser considerado o uso da nevirapina nessa situação.

5. O esquema de AZT (ou d4T), associado a 3TC e ABC, pode ser utilizado em casos de impossibilidade de uso de EFV e da combinação SQV/RTV, como em casos de toxicidade e hepatopatia grave. No entanto, este esquema é menos potente que aqueles que incluem EFV e SQV/RTV e é mais freqüentemente associado à falha terapêutica.

6. Em caso de necessidade absoluta de manutenção de droga anti-retroviral incompatível com uso concomitante de rifampicina, deve-se tratar a TBC durante 12 meses com o esquema recomendado pelo Ministério da Saúde para casos de intolerância ou contraindicação para uso de rifampicina (dois meses iniciais com $\mathrm{H}+\mathrm{Z}+\mathrm{S}+\mathrm{E}$, seguidos de 10 meses com $\mathrm{H}+\mathrm{E}$ [2HEZS/10HE]).

7. Dois meses iniciais com $\mathrm{R}+\mathrm{H}+\mathrm{Z}$, seguidos de sete meses com $\mathrm{R}+\mathrm{H}(2 \mathrm{RHZ} / 7 \mathrm{RH})$. Observar que doses mais elevadas de rifampicina e isoniazida são recomendadas nessa situação.

8. Dois meses iniciais com $\mathrm{R}+\mathrm{H}+\mathrm{Z}+\mathrm{E}$, seguidos de quatro meses com $\mathrm{R}+\mathrm{H}+\mathrm{E}$ (2RHZE/4RHE).

9. Recomenda-se monitorar rigorosamente a adesão (tratamento supervisionado) e coletar material para teste de sensibilidade aos medicamentos antituberculose.

10. Três meses iniciais com $\mathrm{S}+\mathrm{Et}+\mathrm{E}+\mathrm{Z}$, seguidos de nove meses com Et+E (3SEtEZ/9EtE). 


\section{ANEXO 3A - TERMO DE CONSENTIMENTO LIVRE E ESCLARECIDO $\mathbf{1}^{\mathrm{a}}$ via - PACIENTES}

$\mathrm{O}$ (a) senhor(a) está sendo convidado a participar da pesquisa Adesão aos Antiretrovirais por pacientes com aids, tuberculose e usuários de drogas, que é parte da tese de doutorado sob responsabilidade da pesquisadora Helena Maria Medeiros Lima, e orientação do Dr. Péricles Alves Nogueira - do departamento de Epidemiologia da Faculdade de Saúde Pública da USP.

Sua participação é voluntária, sigilosa, e sua desistência não trará qualquer prejuízo

para você ou seu atendimento. Será muito importante para compreendermos melhor a questão da adesão aos medicamentos, e melhorarmos as estratégias já existentes.

Será feita uma entrevista, com duração aproximada de 40 minutos, a respeito da sua medicação e tratamento com antiretrovirais. A entrevista será gravada, e apenas a entrevistadora Raquel Queiroz e a pesquisadora Helena Lima terão acesso às gravações originais.

$\mathrm{O}$ (a) senhor (a) pode pular, não responder a qualquer pergunta sem dar satisfações, ou mesmo interromper a entrevista sem qualquer explicação.

Qualquer dúvida, pode entrar em contato com Dr. Péricles Nogueira, telefone 3066.7730, em horário comercial.

Declaro que li ou leram para mim, e concordo em participar da pesquisa.

Local e data: , 1

Assinatura do entrevistado:

Local e data: , $1-1$

Assinatura do entrevistador: 


\section{ANEXO 3B - TERMO DE CONSENTIMENTO LIVRE E ESCLARECIDO PARA PROFISSIONAIS DE SAÚDE DA REDE PÚBLICA DE SAÚDE DE SÃO PAULO}

O senhor está sendo convidado a participar de uma pesquisa de Doutorado, realizada pela bióloga e psicóloga Helena Lima, do Departamento de Epidemiologia da Faculdade de Saúde Pública da USP. O objetivo é estudar a adesão dos pacientes com aids/tuberculose e usuários de drogas ao tratamento anti-retroviral (ARV). Esta pesquisa está sendo orientada pelo Prof. Dr. Péricles Alves Nogueira.

A questão da adesão tem sido amplamente discutida, e há poucos estudos no Brasil com os pacientes usuários de drogas. Como parte desta pesquisa está a realização de entrevistas em profundidade com profissionais de saúde que trabalhem diretamente com pacientes com este perfil (pacientes com aids/tuberculose usuários de drogas), em serviços públicos de saúde do Estado de São Paulo. Sua entrevista terá a duração aproximada de 30 minutos e será gravada. Somente a entrevistadora e a pesquisadora principal terão acesso à fita.

Caso concorde em participar, seu anonimato será totalmente preservado, e o senhor pode se recusar a responder a quaisquer perguntas, interromper a entrevista ou pular respostas, sem qualquer conseqüência. O senhor pode interromper a qualquer momento para tirar dúvidas.

Os riscos para participar desta pesquisa são mínimos, e referem-se à sua mobilização pessoal em relação aos temas abordados - tuberculose, aids e drogas. Os benefícios serão o maior conhecimento acerca do tema da adesão aos tratamentos, ainda pouco explorados no Brasil.

Se após a entrevista surgirem dúvidas, o senhor poderá entrar em contato com a pesquisadora responsável, Helena Lima, no Departamento de Epidemiologia da Faculdade de Saúde Pública da USP, no telefone (0**11) 30667730.

Declaro que li e aceito participar da pesquisa e estou ciente e concordo que minha entrevista seja gravada

Data e local:

Assinatura:

Data e local:

Assinatura da pesquisadora responsável: 


\section{ANEXO 4 - ROTEIRO PARA ENTREVISTADORAS - OBSERVAÇÃO E MAPEAMENTO}

\section{SERVIÇO}

2. DATA

\section{HORÁRIO}

\section{LOCAL DA REALIZAÇÃO DESTA OBSERVAÇÃO NO SERVIÇO}

5. DADOS DA INFRA-ESTRUTURA DO LOCAL: espaço físico, número de salas, local disponibilizado para realização das entrevistas, dinâmica cotidiana

6. DADOS DO ORGANOGRAMA: cargos, atribuição de funções, serviços rotineiramente oferecidos aos pacientes, treinamentos, rotina administrativa, rotina de agendamento e disponibilização de medicamentos, interação com outras unidades.

7. INTEGRAÇÃO MULTIPROFISSIONAL: composição da equipe, formas de integração entre os membros participantes, critérios para discussão clínica de casos, parceiras com rede social de apoio (ONG, PSF, etc.).

8. INSERÇÃO DA UNIDADE NA COMUNIDADE LOCAL: programas oferecidos para a comunidade, divulgação dos serviços assistenciais oferecidos, projetos envolvendo parceiros locais para assistência às populações vulneráveis.

9. DINÂMICA COTIDIANA: horário de atendimento ao público, possibilidades de flexibilização, divulgação dos serviços prestados, diálogo entre administração (direção do serviço) e demais funcionários, variações na dinâmica em função de datas específicas (feriados) e adaptações necessárias em decorrência de imprevistos (por exemplo, falta de medicamentos para aids).

10. TRATAMENTO DE TUBERCULOSE NO SERVIÇO DE DST e AIDS: infraestrutura física (salas disponibilizadas, profissionais responsáveis, etc.), materiais didáticos e de orientação (folhetos, folders, etc), recomendações para imunização. 


\section{ANEXO 5 - ROTEIRO SEMI-ESTRUTURADO PARA PROFISSIONAIS DE SAÚDE}

\section{Parte 1 - Perfil profissional}

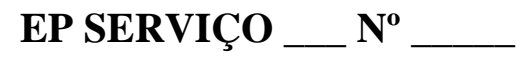

1. Idade: Sexo:

2. Formação (local, instituição e data):

3. Residência (para médicos):

4. Especialização:

5. Tempo de atuação profissional em geral:

6. Tempo de trabalho em HIV/Aids e local:

7. Trabalho atual: locais/ funções

8. Experiência específica com tuberculose:

9. Experiência com dependentes químicos:

\section{Parte 2 - Qualitativa}

1. Fale um pouco sobre sua rotina de trabalho aqui no serviço...

2. Frente ao paciente com aids, como faz para buscar tuberculose?

- existe um protocolo a ser seguido?

- é feita busca de contactantes?

- como é feita a orientação para o paciente e para a família?

3. Como você identifica um paciente usuário de drogas psicotrópicas?

- (se o profissional não mencionar álcool, incluir: "e o paciente usuário de álcool?")

4. Quais os medicamentos mais empregados atualmente para o tratamento da aids? Como você avalia a posologia mais adequada para determinado paciente?

5. O que você tem observado em relação a fatores que ajudam na eficiência dos tratamentos para aids? E para tuberculose?

6. Como seriam os pacientes "difíceis" ou "fáceis" em relação ao tratamento? O que determinaria esse perfil, em sua opinião?

7. Quais os efeitos da interação dos anti-retrovirais com drogas psicotrópicas? 
8. Fale a respeito dos pacientes com tuberculose neste serviço:

- Acompanhamento,

- $\quad$ tipo de tratamento oferecido (supervisionado ou auto-administrado),

- perfil do paciente,

- busca de faltosos e/ou ausentes,

- busca de contactantes e paciente-fonte,

- registro de casos no serviço.

9. Em sua opinião, o que facilita a adesão do paciente a terapia ARV? E o que dificulta?

- Quais são os efeitos colaterais mais freqüentes? Como interferem no tratamento e na adesão do paciente?

- Quais os critérios para troca de esquema terapêutico?

10. Fale um pouco sobre a falência terapêutica - o que é? E resistência? Comente um pouco sobre subtipos de HIV. O que é genotipagem? E tuberculose multidrogarresistente?

11. Como você faz quando precisa de uma informação sobre interação farmacológica? E os problemas do dia-a-dia, a quem recorre?

12. O que você acha importante para os médicos fazerem para ajudar os pacientes mais "difíceis" a aderir a terapia? E os outros profissionais de saúde (enfermagem, farmácia, psicologia, etc.?

Somente para SM2 - Comente sobre os pacientes institucionalizados (presos ou menores na Febem) e foragidos da polícia em relação à adesão aos medicamentos. Problemas? Alternativas para resolução?

13. Gostaria de comentar alguma outra coisa?

Obrigada pela atenção e participação! 


\section{ANEXO 6 - ROTEIRO SEMI-ESTRUTURADO PARA ENTREVISTAS COM \\ PACIENTES}

\section{Parte I - Caracterização do paciente selecionado}

Iniciais: Sexo:

Idade: (data de nascimento)

Profissão/ ocupação:

Estado Civil:

Natural de:

Onde e com quem mora:

Escolaridade:

Número de filhos:

Há quanto tempo tem diagnóstico de HIV+:

Há quanto tempo está tratando neste serviço:

Tuberculose:

Esquema atual para tratamento da aids:

Esquema atual para tratamento da tuberculose:

\section{Parte II - Parte Qualitativa}

1. Como é um 'dia comum' seu? (dia típico)?

- Atividades diversas - local de moradia, trabalho (se houver)

- Como vem para o tratamento (condução, usa vale-transporte, etc)

- Alimentação, rotina, atividades diversas (físicas, profissionais) - quais as diferenças de quando não era HIV+?

2. Comente sobre seu diagnóstico de HIV (quem deu, quando, onde, por que procurou fazer o teste). Que sugestões você teria para melhorar esse serviço?

3. Quantos testes você já fez, onde e por quê?

4. Como foi o período desde o diagnóstico de HIV até o começo da terapia ARV? (tratamento, aconselhamento, acompanhamento).

5. Como é sua vida afetiva, hoje em dia? Tem parceiro fixo? Fazem algum tipo de prevenção? Qual?

6. Vamos falar um pouco sobre o seu tratamento atual para HIV/Aids...

- Quando começou?

- Qual o esquema atual?

- Comente o tratamento que está fazendo, do modo mais detalhado possível... (quando busca medicamentos, quem orienta, etc.)? 
- Já abandonou o tratamento ARV? Por quê?

- O que fez com que você voltasse a se tratar?

7. O que você acha que ajuda você a tomar a medicação?

- clareza da explicação do médico

- piora no quadro clínico

- exposição a sexo sem proteção

- exigência/ participação da família

- religião

- número de comprimidos

- efeitos colaterais

8. Fale um pouco sobre sua tuberculose

9. Como é o tratamento atual para tuberculose que você está fazendo? Detalhe.

10. Comente sobre os medicamentos - o que atrapalha para se tomar os medicamentos no dia-adia?

- clareza da explicação do médico

- piora no quadro clínico

- $\quad$ exposição a sexo sem proteção

- exigência/ participação da família

- religião

11. Comente sobre o (seu) uso de drogas (incluindo álcool).

- Com quantos anos você começou a usar drogas?

- Que drogas você já utilizou?

- Ainda faz uso de drogas? Quais?

12. Com quem você fala sobre seu uso de drogas, no serviço e fora dele? Que tipo de influência teve ou tem no tratamento?

13. Quando você tem dúvidas sobre o tratamento, como faz?

14. Que tipo de ocorrência você já passou em relação a interrupção do tratamento? Detalhar (falta de medicamento, efeito colateral, perdeu a data para buscar, etc.)

15. Que sugestões você teria para os profissionais de saúde, para ajudarem aos pacientes que têm aids e tuberculose, e são usuários de drogas a fazer um bom tratamento?

16. Algum comentário sobre a entrevista?

Muito obrigada 


\section{ANEXO 7 - CATEGORIAS E SUB-CATEGORIAS DE ANÁLISE QUALITATIVA/ PACIENTES}

\section{Tuberculose:}

(a) número e tipos de tuberculoses,

(b) lembranças do tratamento: época, tempo de duração, remédios, local, problemas,

(c) dificuldades encontradas durante o tratamento,

(d) comportamentos modificados após diagnóstico: vida afetiva, sexual, social,

(e) diagnóstico de tuberculose: época, forma, relação com HIV.

\section{Fatores que facilitam adesão:}

(a) aspectos biológicos:

(a1) relativos aos efeitos colaterais,

(a2) relativos às interações com outras drogas,

(a3) relativos ao número de comprimidos,

(b) aspectos sociais:

(b1) acesso aos medicamentos,

(b2) atendimento no serviço,

(b3) locomoção/ deslocamento até o serviço,

(c) aspectos psicológicos:

(c1) apoio família/ parceiro,

(c2) ocupação,

(c3) doenças pré-existentes,

(c4) vida afetiva atual,

(c5) vida sexual,

\section{Fatores que dificultam adesão:}

(a) aspectos biológicos:

(a1) relativos aos efeitos colaterais,

(a2) relativos às interações com outras drogas,

(a3) relativos ao número de comprimidos,

(a4) lipodistrofia.

(b) aspectos sociais:

(b1) acesso aos medicamentos, 
(b2) atendimento no serviço,

(b3) locomoção/ deslocamento até o serviço,

(c) aspectos psicológicos:

(c1) apoio família/ parceiro,

(c2) ocupação,

(c3) doenças pré-existentes,

(c4) vida afetiva atual,

(c5) vida sexual atual,

- camisinha

\section{Drogas:}

(a) uso atual de drogas - psicoativos:

(a1) tipo de droga que usa,

(a2) forma de uso,

(a3) freqüência de uso,

(a4) comunicação deste uso atual de drogas no serviço de saúde,

(b) uso anterior de drogas psicoativas:

(b1) início do uso de drogas,

(b2) tipo de droga utilizada,

(b3) acréscimo de outras drogas/ quais,

(b4) histórico de overdoses ou acidentes decorrentes do uso,

(c) uso de drogas e tratamento de aids:

(c1) interrupções no uso,

(c2) motivos das interrupções,

(c3) comunicação das interrupções para profisssional de saúde,

(d) crenças sobre interações medicamentosas:

(d1) estratégias para manter o vínculo institucional,

(d2) estratégias para omitir as falhas do profissional de saúde,

(e) estratégias de proteção:

(e1) comportamentos de recuperação após falhas severas,

(e2) vínculos com ONG ou outros serviços para esclarecimentos, 


\section{Tratamento de aids e de tuberculose:}

\subsection{Tuberculose:}

(a) tempo de diagnóstico de tb,

(b) motivo da realização do teste,

(c) medidas profiláticas - orientações,

(d) tipo de tratamento realizado,

(e) tempo de tratamento,

(f) dificuldades surgidas,

(g) sugestões para profissionais de saúde.

\subsection{Aids:}

(a) tempo de diagnóstico de HIV,

(b) tipo de tratamento realizado motivo da realização do teste,

(c) orientações sobre saúde sexual e reprodutiva,

(d) tempo de tratamento,

(e) dificuldades surgidas - estratégias de superação,

(f) sugestões para profissionais de saúde. 


\section{ANEXO 8 - CATEGORIAS E SUB-CATEGORIAS DE ANÁLISE QUALITATIVA/ PROFISSIONAIS DE SAÚDE}

\section{Tuberculose:}

(a) experiência prévia de atendimento,

(b) capacitação técnica prévia e atual,

(c) fluxo de tuberculose no serviço de DST/Aids.

(d) mecanismos de busca ativa de contactantes, pacientes fonte, etc.

(e) interação com outros profissionais da tuberculose

(f) programas de apoio (saúde da família, ONG, igrejas)

\section{Drogas:}

(a) experiência prévia de atendimento de pacientes usuários de drogas,

(b) capacitação técnica para atendimento,

(c) identificação de pacientes que são usuários de drogas na rotina do serviço,

(d) condução do atendimento destes pacientes,

(e) dificuldades enfrentadas no atendimento,

(f) soluções apresentadas em situações-limite,

(g) estratégias de encaminhamento.

\section{Conhecimentos técnico-científicos:}

(a) genotipagem para HIV,

(b) falência terapêutica:

(b1) conceito geral,

(b2) do tratamento para aids,

(b3) do tratamento de tuberculose,

(b4) tuberculose multidrogarresistente,

(c) resistência aos medicamentos:

(c1) relação com adesão,

(c2) relação com uso de drogas,

(c3) relação com tuberculose,

(e) sub-tipos de HIV,

(f) informações e atualizações:

(f1) sobre farmacocinética, 
(f2) interações medicamentosas,

(f3) cotidiano de atendimento

(g) Atendimentos a populações vulneráveis:

(g1) da população em situação de rua,

(g2) da população reclusa.

\section{Fatores que influenciam a adesão do paciente ao tratamento:}

(a) Facilitadores,

(b) Prejudiciais,

(c) Sugestões para melhoria da questão da adesão no Brasil. 


\section{ANEXO 9 - CODIFICAÇÃO DOS DADOS - ESTRUTURA DOS SERVIÇOS DE DST/AIDS}

\section{Estrutura geral:}

(a) tipo de serviços oferecidos ao público:

(a1) vínculo com unidades de saúde mental, (a2) relação com ONG próximas,

(a3) articulação com rede social de apoio,

(b) estrutura geral da unidade:

(b1) espaço físico,

(b2) localização do serviço de tuberculose,

(b3) setor de redução de danos.

(c) número de pacientes atendidos:

(c1) com aids,

(c2) com tuberculose,

(c3) de outros serviços.

\section{Fluxo dos pacientes co-infectados aids/tb na unidade:}

(a) atendimento a pacientes co-infectados aids/tb:

(a1) estratégias de atendimento do paciente, (a2) fluxo do paciente na unidade,

(a3) dificuldades enfrentadas no cotidiano, (a4) busca de contactantes e pacientes-fonte.

(b) relação do serviço de DST/Aids:

(b1) com Programa de Tuberculose:

(b.1.1) planilhas,

(b.1.2) prontuários.

(b2) com área de Saúde Mental:

(b.2.1) encaminhamentos recebidos, (b.2.2) fluxo de encaminhamentos na comunidade. 


\section{ANEXO 10 - CODIFICAÇÃO SPSS - PACIENTES}

1. Para a categoria idade:

1) $18-25$,

2) $26-30$,

3) $31-35$,

4) $36-40$,

5) $41-45$,

6) $46-50$,

7) $51-55$,

8) $56-60$,

9) $61-65$,

99) Não informou.

2. Para a categoria sexo, os códigos foram:

1) Sexo Masculino,

2) Sexo Feminino.

3. A categoria Estado Civil foi codificada da seguinte forma:

1) Solteiro,

2) Casado,

3) Separado / divorciado,

4) Amasiado,

5) Viúvo,

99) Não informou.

4. Tempo de Infecção pelo HIV (intervalos de 5 anos)

1) $1-5$,

2) $6-10$,

3) $11-15$,

4) $16-20$,

5) $21-25$,

6) $26-30$,

88) Não sabe,

99) Não informou.

5.Tempo de Tratamento (intervalo de 5 anos)

1) $1-5$,

2) $6-10$,

3) $11-15$,

4) $16-20$,

5) $21-25$, 
6) $26-30$,

7) $31-35$,

8) $36-40$,

88) Não sabe,

99) Não informou.

6. Quanto ao uso de psicoativos, a pergunta e a codificação foram as seguintes:

6.1. Ainda usa droga?

1) Sim,

2) Não,

99) Não informou.

6.2. Drogas: as drogas mencionadas pelos entrevistados foram listadas e geraram variáveis, que responderiam à questão usa a droga $X$ ?

1) Sim,

2) Não,

99) Não informou.

Cada droga mencionada foi tabulada segundo essa pergunta, para se avaliar individualmente qual seria a droga mais utilizada, pois vários entrevistados disseram usar mais de um tipo de droga. Por exemplo:

Maconha:

1) Sim,

2) Não.

Cocaína:

1) Sim,

2) Não.

7. Em relação ao tipo de tratamento atual para aids, a tabulação foi feita em função do nome do medicamento obtido em prontuário. Por exemplo:

Estavudina 1) Sim,

2) Não,

77) Não faz uso de TARV,

99) Não informou.

7.1 Esquema de TARV em uso: Com os dados fornecidos pelos médicos dos respectivos entrevistados. Cada TARV foi assim codificada:

1) Biovir e Efavirenz,

2) D4T, 3TC e EFV,

3) Abacavir, 3TC e Efavirenz,

4) Biovir e Kaletra,

5) D4T, 3TC, Indinavir e Ritonavir,

6) D4T, 3TC e Kaletra,

7) DDI, 3TC e Kaletra, 
8) DDI, AZT e Kaletra,

9) Biovir, Ritonavir e Atazanavir,

10) DDI, AZT e Nevirapina,

11) Lamivudina e AZT,

12) Efavirenz e AZT,

13) 3TC, D4T, Ritonavir e Saquinavir,

77) Não faz uso de TARV,

99) Não informou.

8. Escolaridade - em anos:

1) $1-3$,

2) $4-7$,

3) $8-11$,

4) $12-15$,

88) Não sabe,

99) Não informou.

9. Escolaridade - em nível de ensino:

1) Fundamental I incompleto,

2) Fundamental I completo,

3) Fundamental II incompleto,

4) Fundamental II completo,

5) Ensino Médio incompleto,

6) Ensino Médio completo,

7) Ensino Superior incompleto,

8) Ensino Superior completo,

88) Não sabe,

99) Não informou.

10. Abandono de tratamento de aids:

1) Sim,

2) Não,

77) Não faz uso de TARV,

88) Não sabe,

99) Não informou.

11. Número de interrupções do tratamento da aids: variável numérica.

00) Nunca interrompeu,

88) Não se lembra quantas vezes interrompeu,

99) Não informou. 
12. O mesmo se aplicou quanto ao item uso de psicoativos - 'Droga em uso'. Portanto, pode-se verificar qual o medicamento mais utilizado por este universo de pacientes, bem como se estão utilizando ao mesmo tempo e qual o tipo de droga utilizada.

1. Álcool,

2. Maconha,

3. Cocaína,

4. Crack,

5. Álcool + Cocaína,

6. Maconha + Crack,

77. Não faz mais uso de drogas,

99. Não informou.

13. Forma de contágio de HIVlaids:

1) Sexual,

2) Sanguínea,

3) Acidente biológico,

88) Não sabe,

99) Não informou.

14. Idade, em anos, do primeiro uso de drogas (faixa etária)

1) $11-15$,

2) $16-20$,

3) $21-25$,

4) $26-30$,

5) $31-35$,

6) $36-40$,

88) Não sabe,

99) Não informou.

15. Primeira droga usada:

1) Álcool,

2) Maconha,

3) Cocaína,

4) Crack,

5) Cola,

99) Não informou.

16. Não foi possível recuperar em detalhes o tipo de tratamento feito para tuberculose, nem os nomes dos medicamentos utilizados, nem o tempo de tratamento com precisão. Não há registros precisos nos prontuários e os pacientes não têm essa informação.

17. Religião

1) Católica, 
2) Evangélica,

3) Espírita,

88) Não tem religião,

99) Não informou.

18. Mudou de religião após sorologia?

1) Sim,

2) Não,

88) Não tem religião,

99) Não informou.

19. Porque aderiu ao tratamento de HIV/Aids? São várias opções, e foram transcritas as palavras-chave.

1) Vontade de viver,

2) Doença Oportunista,

3) Diminuição do número dos comprimidos,

4) Boa relação com a médica,

5) Fé,

6) Não quer abusar de Deus, pois Deus o curou,

7) Família,

8) Acolhido pelo serviço,

9) Não aderiu completamente,

10) Medo da morte,

77) Não faz uso de TARV,

99) Não informou.

20. Recaídas de tuberculose:

1) Sim,

2) Não,

88) Não sabe,

99) Não informou.

21. Tipos de Tuberculose:

1) Pulmonar,

2) Encefálica,

3) Ganglionar,

4) Pâncreas, Intestino e Fígado.

22. Já teve quantas Tuberculoses ao longo da vida? (variável numérica)

23. Qual foi o tipo de tratamento na(s) Tuberculose(s) anterior(es)?

1. TS - TB Supervisionada,

2. TSI - TB Supervisionado com internação,

3. TA - TB Auto-administrada,

4. TA + TSI, 
5. Não se tratou,

77) Não houve TB anteriores,

99) Não informado.

24. Qual foi o tipo de tratamento na Tuberculose atual?

1) TS - TB Supervisionada,

2) TSI - TB Supervisionado com internação,

3) TA - TB Auto-administrada,

4) $\mathrm{TA}+\mathrm{TSI}$,

5) Não se tratou,

77) Não houve TB anteriores,

99) Não informado.

25. Sabe qual é o esquema em uso da Tuberculose atual?

1) Sim,

2) Não,

3) Não se tratou,

99) Não informou.

26. Abandonou o tratamento atual de Tuberculose?

1) Sim,

2) Não,

3) Aguarda tratamento,

99) Não informou.

27. Serviço em que realiza atendimento:

1) SM 1 ,

2) SM 2 ,

3) $\mathrm{SM} 3$,

4) SE 4. 


\section{ANEXO 11 - DADOS DE CODIFICAÇÃO SPSS - PROFISSIONAIS DE SAÚDE}

1. Sexo:

1) Masculino,

2) Feminino,

99) Não informou.

2. Idade (em anos):

1) $18-25$,

2) $26-30$,

3) $31-35$,

4) $36-40$,

5) $41-45$,

6) $46-50$,

7) $51-55$,

8) $56-60$,

9) $61-65$,

88) Não sabe,

99) Não informou.

3. Formação:

1) Não-médico,

2) Médico.

4. Tempo de trabalho como profissional na área de saúde em geral (em anos):

1) $1-5$,

2) $6-10$,

3) $11-15$,

4) $16-20$,

5) $21-25$,

6) $26-30$,

7) $31-35$,

8) $36-40$,

9) $41-45$.

5. Tempo de atuação em trabalho específico com aids (em anos):
1) $1-5$,
2) $6-10$,
3) $11-15$,
4) $16-20$,
5) $21-25$,

6. Serviço ao qual pertence atualmente:

1) $\mathrm{SM} \mathrm{1,2)} \mathrm{SM} \mathrm{2,}$

3) SM 3, 4) SE 4. 